Lívia Petelincar De Sordi

\title{
Diversidade funcional de aves em fitofisionomias de Cerrado nativo e substituído
}

\author{
Bird functional diversity in native Cerrado physiognomies \\ and converted areas
}

São Paulo

2021 


\author{
Universidade de São Paulo \\ Instituto de Biociências
}

Programa de Pós-graduação em Ecologia

Lívia Petelincar De Sordi

\title{
Diversidade funcional de aves em fitofisionomias de Cerrado nativo e substituído
}

\author{
Bird functional diversity in native Cerrado physiognomies \\ and converted areas
}

Tese apresentada ao Instituto de Biociências da Universidade de São Paulo para a obtenção do título de Doutora em Ciências na área de Ecologia.

Orientadora: Dra. Vânia Regina Pivello

EXEMPLAR CORRIGIDO

São Paulo 


\section{Ficha Catalográfica}

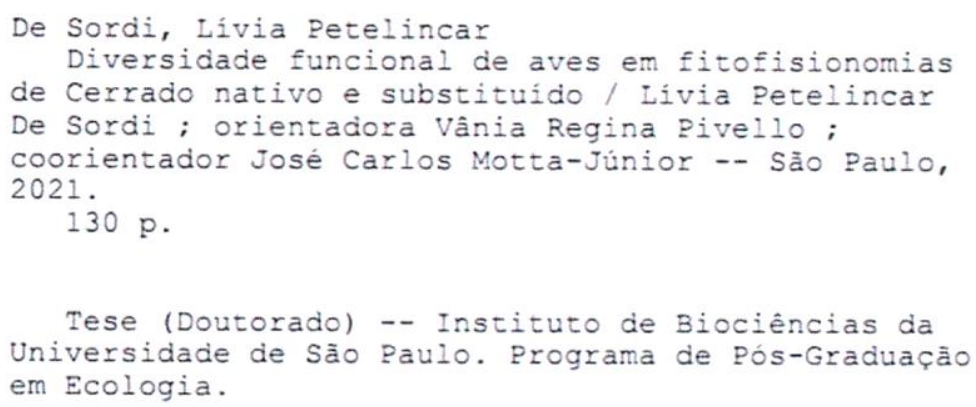

1. Diversidade de aves. 2. Distribuição de aves. 3. Comunidade de aves. 4. Pastagem. 5. Plantio de eucaliptos. I. Pivello, Vânia Regina, orient. II. Motta-Júnior, José Carlos, coorient. III. Titulo.

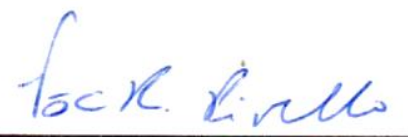

Orientadora: Profa. Dra. Vânia Regina Pivello 
Comissão Julgadora:

Profa. Dra. Érica Hasui

Profa. Dra. Andrea Larissa Boesing

Profa. Dra. Rozely Ferreira dos Santos

Profa. Dra. Vânia Regina Pivello

Orientadora 


\section{EPÍGRAFE}

"A questão não é o que você olha, mas como você olha e se você vê."

Henry David Thoreau 


\section{DEDICATÓRIA}

À minha mãe, meu pai e minha irmã. 


\section{AGRADECIMENTOS}

Agradeço à minha orientadora Vânia pela confiança e paciência. Tive a sorte de ter ao meu lado uma professora e amiga atenciosa e cuidadosa, que me proporcionou segurança e me encorajou a ter persistência e confiança nos momentos de dificuldade que surgiram nesse caminho. Foi uma grande alegria ter dividido esse percurso com alguém tão compreensiva e empática. Também sou muito grata ao meu coorientador José Carlos Motta-Júnior, que me dedicou tanto do seu tempo e atenção na identificação das aves. Sem o seu conhecimento e sua vontade de dividir seus saberes não seria possível ter cumprido essa etapa.

O doutorado não foi para mim apenas um caminho de aprendizagem teórica e prática em Ecologia. Foram anos em que fui continuamente desafiada a me conhecer melhor e a aceitar minhas limitações, para ao final entender que o percurso de cada um guarda muitos passos pequenos, tropeços, saltos, quedas e alegrias e que por isso não são comparáveis. Na academia sempre nos salta aos olhos os resultados finais, mas dos percursos, pouco sabemos. Não conhecemos o que guarda cada pessoa por trás do texto e das palavras, não mensuramos o sentir e o querer que perpassa o pensar. Não descrevemos nos Métodos, os esforços pessoais e emocionais que as viagens de campo demandaram. Pouco se fala dos medos, das frustrações, das esperanças e das ansiedades. Nossas pesquisas se baseiam em demonstrações e provas, buscamos acessar um conhecimento que está fora de nós, e pouco ou nada olhamos para dentro de cada um. Por mais coautores que os grandes trabalhos envolvam, na maioria das vezes o caminho é solitário.

O doutorado me colocou em uma trilha de aprendizagem pelo não dito. A construção da estrutura que alicerça quem se é, nessa fase, só é possível após a desconstrução de paredes frágeis. Por isso, para mim foi fundamental contar com a presença dos meus amigos: Alexandre, Fábio, Débora, Leandro, Lucas e Karina. Agradeço a todos os momentos partilhados. Também tive a alegria de poder confiar nos meus amigos de faculdade: Nathália, Rafael, Cíntia, Adriano e Daniela, que pela companhia e pela escuta, me ajudaram a dividir as dificuldades e somar as alegrias. 
Tive a sorte de encontrar na Pós em Ecologia pessoas muito especiais como a Luanne e o Renato, que foram representantes discentes do Programa de Pós-Graduação em Ecologia. Não me esqueço também dos alunos do grupo Café Existencial, como o Lucas e o Rodolfo, que nos ajudaram a construir um lugar de fala e de acolhimento, onde pudemos nos sentir menos sozinhos e dividir momentos de alegria e leveza. Não posso deixar de ser grata também à Vera, uma mulher e profissional cuja dedicação possibilita a continuidade do Programa de Pós em Ecologia e me trouxe calma em muitos momentos.

Tive o prazer de contar com a ajuda voluntária de duas amigas do laboratório LEPAC, nas viagens para coleta dos dados: Thatiana Maeda e Alessandra Rocha Kortz. Agradeço essas companhias, pois apesar do trabalho de campo muitas vezes ser cansativo e difícil, ele se tornou muito mais fácil e prazeroso nos momentos em que estive com essas pessoas.

Agradeço ainda à Mariana Vidal e Rochely Morandini pela parceria na análise dos dados que resultaram no capítulo 1 desta Tese. Do mesmo modo, o Renan foi essencial para a análise estatística dos dados apresentados no capítulo 2. Também sou grata ao Prof. Dr. Leandro Tambosi pelo acompanhamento e sugestões nas reuniões de Comitê e ao Prof. Dr. Marco Mello pelo olhar atento, justo e generoso com que conduziu a banca do exame de Qualificação. Não menos importante, também agradeço ao Dr. Pedro Develey e Profa. Dra. Cristina Yumi Miyaki pelas sugestões nesse mesmo exame.

Agradeço aos motoristas do Instituto de Biociências da USP: Sr. Valmir e Sr. Amaral, que foram essenciais para que as viagens de coleta de dados pudessem acontecer. Ao funcionário Sr. Waldonésio e ao gestor Fabrício, do Parque Estadual de Vassununga, que nos receberam tão atenciosamente em Santa Rita do Passa Quatro. Também agradeço aos funcionários e gestores da Estação Ecológica de Itirapina e da Estação Ecológica de Águas de Santa Bárbara. A colaboração dessas pessoas foi crucial para que o trabalho de campo pudesse ser executado. Não menos importante, agradeço aos proprietários das terras que, ao compreenderem a importância do presente trabalho, autorizaram a coleta de dados em suas propriedades.

Sou grata a todos os funcionários do Instituto de Biociências e à Comissão Coordenadora do Programa de Pós-Graduação em Ecologia, que compreendeu o momento difícil de pandemia do coronavirus e deu suporte e assistência aos alunos de 
Pós-graduação para que conseguissem dar continuidade e finalizar seus trabalhos. Agradeço também os esforços individuais de tantos brasileiros cujos impostos pagos me permitiram receber o financiamento da CAPES por meio da bolsa de doutorado. Assim, também agradeço à essa agência de fomento que torna viável grande parte das pesquisas no Brasil.

Por fim, agradeço a minha mãe, meu pai e minha irmã que, como sempre, estiveram ao meu lado e me apoiaram durante essa caminhada e cuja dedicação e amor eu não poderia explicar em palavras.

Concluo essa seção trazendo à consciência um insight que tive ao final desses anos de doutorado: o meu encanto pela Ecologia não germinou do conhecimento teórico, mas nasceu por ela ser o lugar que estuda as relações e que entende que nada está ou é sozinho. 


\section{SUMÁRIO}

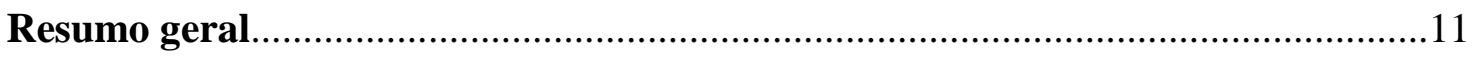

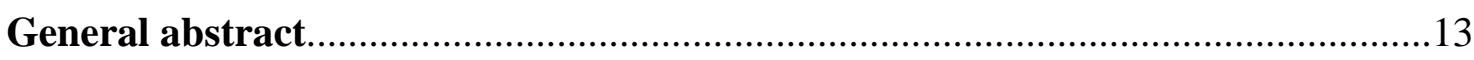

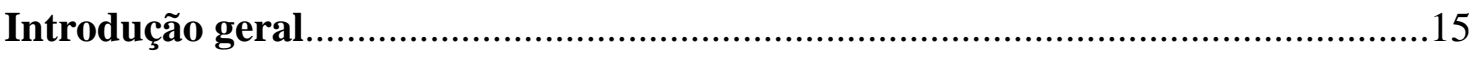

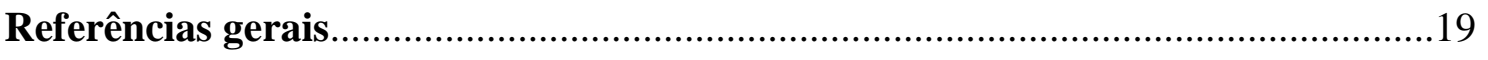

Capítulo 1: The biogeographic network of birds in the Brazilian Cerrado............22

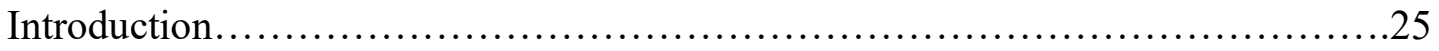

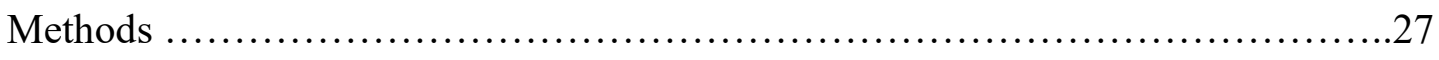

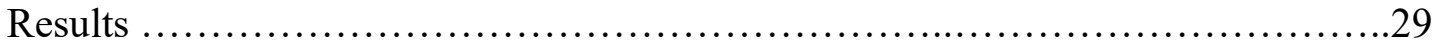

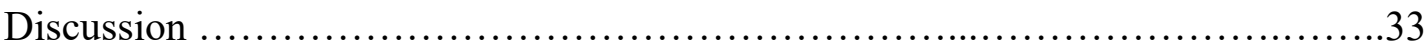

References ......................................................... 36

Capítulo 2: Riqueza e composição da avifauna em ambientes de cerrado nativo e

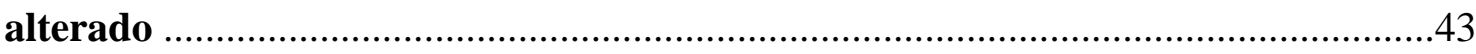

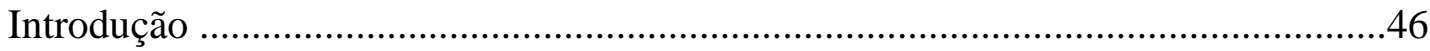

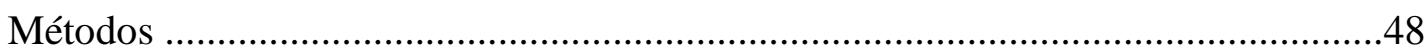

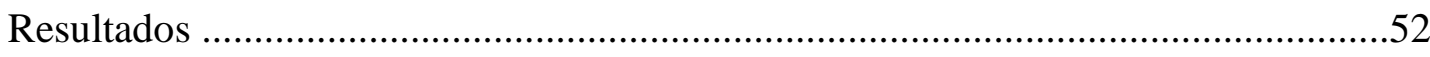

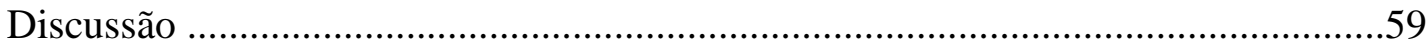

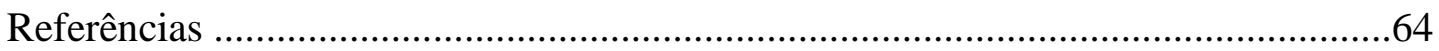

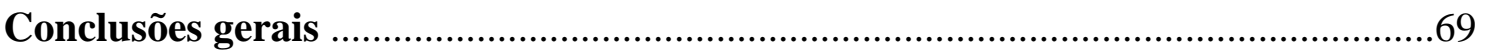

\section{Supplementary Material - Capítulo 1}

Table S1 ......................................................... 71

Table S2 ............................................................ 75

Table S3 .................................................... 76

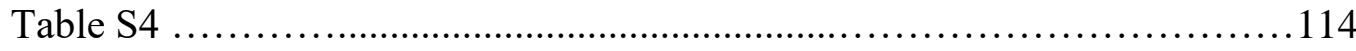

Material Suplementar - Capítulo 2

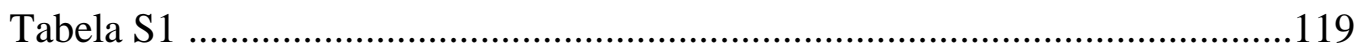

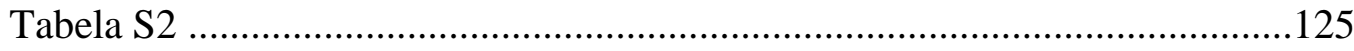

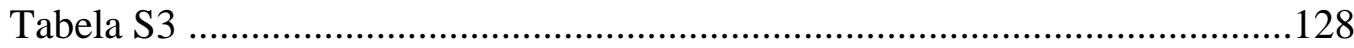




\section{RESUMO GERAL}

DE SORDI, Lívia Petelincar. Diversidade funcional de aves em fitofisionomias de Cerrado nativo e substituído. 2021. 130 f. Tese (Doutorado em Ecologia) - Instituto de Biociências, Universidade de São Paulo, São Paulo, 2021.

O Cerrado é a savana que apresenta maior riqueza em espécies no mundo, mas que se encontra fortemente ameaçada, o que torna o bioma um hotspot de biodiversidade. Dentre as principais ameaças que levam à perda de áreas naturais, o crescimento da fronteira agrícola é a principal delas. Além disso, em nível nacional, as áreas da região nuclear do Cerrado (ou Core) tem recebido mais esforços de conservação do que as áreas marginais, por serem consideradas os principais refúgios da biodiversidade do bioma. No entanto, muitas das regiões marginais também abrigam elevada riqueza de espécies e alta taxa de endemismo. No nível regional, a porção sudeste do Cerrado tem sofrido, além da perda de áreas nativas, a perda das fitofisionomias abertas. As aves representam um grupo biológico altamente diverso e amplamente distribuído, com uma variabilidade grande de atributos funcionais, o que reflete em funções importantes para a manutenção e o funcionamento dos ecossistemas. Esta tese teve como objetivo ampliar o conhecimento sobre os padrões de distribuição da biodiversidade de aves no Cerrado brasileiro, bem como compreender melhor se e como as diferentes fitofisionomias naturais do Cerrados e de áreas agrícolas diferem entre si com relação à riqueza e diversidade funcional das aves. Desse modo, no primeiro capítulo desenvolvemos uma análise biogeográfica de redes e demonstramos que as composições das comunidades de 42 áreas de Cerrado podem ser divididas em três módulos geograficamente distintos: Noroeste, Centro-Sul e Centro-Norte. Assim, demonstramos que a divisão entre core e não-core não explica a distribuição da avifauna no Cerrado brasileiro. Também avaliamos os papéis que cada área ocupa na rede biogeográfica e mostramos que a maioria das áreas dos módulos Centro-Norte e Centro-Sul apresentam elevado índice de conexão dentro do seu próprio módulo, o que significa que essas áreas guardam uma grande diversidade regional. No capítulo 2 nós avaliamos se a composição e a diversidade funcional de aves diurnas diferem em quatro ambientes: cerrado nativo com fitofisionomia aberta, cerrado nativo com fitofisionomia fechada, pastagem com gramíneas exóticas e silvicultura de eucaliptos sem sobosque de regeneração natural. A partir da coleta em 104 pontos de escuta e observação, nos municípios de Itirapina, Santa Rita do Passa Quatro e Águas de Santa Bárbara, nós amostramos 119 espécies de aves, pertencentes a 39 famílias. As comunidades dos quatro ambientes apresentaram composições distintas, sendo que a silvicultura de eucaliptos apresentou menor riqueza biológica e funcional e a pastagem apresentou maior riqueza funcional multivariada. Quando comparamos as áreas alteradas 
com as áreas naturais, as últimas tiveram mais espécies exclusivas. O cerrado aberto possui número significativamente maior de espécies exclusivamente campestres, enquanto que o cerrado fechado possui mais espécies essencialmente florestais. Assim, demonstramos que cada fitofisionomia abriga uma diversidade de aves específica. Esforços de conservação devem considerar a heterogeneidade espacial e estrutural dos ambientes para garantir a proteção do conjunto da biodiversidade de aves que o bioma Cerrado abriga.

Palavras-chave: Diversidade de aves; Distribuição de aves; Comunidade de aves; Pastagem; Plantio de eucaliptos. 


\section{GENERAL ABSTRACT}

DE SORDI, Lívia Petelincar. 2021. Bird functional diversity in native Cerrado physiognomies and converted areas. $130 \mathrm{f}$. Tese (Doutorado em Ecologia) - Instituto de Biociências, Universidade de São Paulo, São Paulo, 2021.

The Cerrado is the world's savanna that has the greatest species richness, however strongly threatened, what makes this biome a biodiversity hotspot. Among the main threats that lead to the loss of natural areas, the expansion of the agricultural frontier is the main one. In addition, at the national level, Cerrado areas in the core region have received more conservation efforts than marginal areas, as they are considered the main refuges of the biome biodiversity. However, marginal areas are also home to a great number of species and high rates of endemism. At the regional level, the southeastern portion of the Cerrado has experienced great loss of the open phytophysiognomies,. Birds represent a highly diverse and widely distributed biological group, with a wide range of functional attributes, which results in important functions for the ecosystems maintenance and functioning. This thesis aimed to expand the knowledge on the distribution patterns of Cerrado bird biodiversity, as well as to better understand if and how the different natural physiognomies of the Cerrado and of agricultural uses differ in terms of bird richness and functional diversity. Thus, in the first chapter we developed a biogeographic networks analysis and demonstrated that the community composition of 42 Cerrado areas can be divided into three geographically distinct modules: Northwest, Center-South and Center-North. Thus, we demonstrated that the division between core and non-core does not explain the distribution of birds in the Brazilian Cerrado. We also evaluated the roles that each area has in the biogeographic network and showed that most areas of the CenterNorth and Center-South modules have a high rate of connection within their own module, which means these areas have a great regional diversity. In chapter 2 we evaluated whether the composition and functional diversity of diurnal birds differ in four environments: native open Cerrado, native closed Cerrado, pasture with exotic grasses, and eucalyptus silviculture without natural regeneration. At 104 observation and listening sampling points, in the municipalities of Itirapina, Santa Rita do Passa Quatro and Águas de Santa Bárbara, we sampled 119 bird species, belonging to 39 families. Bird communities in the four environments showed different compositions, with eucalyptus silviculture having less biological and functional richness, and pasture with greater multivariate functional richness. When we compare both land uses with the natural areas, the latter had more exclusive species. The open cerrado has a significantly higher number of exclusive grassland species, while the closed cerrado has more essentially forest species. Thus, we demonstrated that each phytophysiognomy houses specific bird diversity. Conservation efforts must consider the spatial and structural heterogeneity of the environments to ensure maximum protection of the Cerrado bird biodiversity. 
Keywords: Bird diversity; Bird distribution; Bird communities; Pasture; Eucalyptus plantation. 


\section{INTRODUÇÃO GERAL}

As savanas são ecossistemas tropicais formados por um estrato contínuo de vegetação herbácea, que pode ou não ter um estrato arbustivo ou arbóreo (Solbrig, 1996). Estão presentes principalmente no continente africano, na Austrália e na América Latina, onde ocorrem na Bolívia, Paraguai e Brasil (Solbrig, 1996). Alguns fatores abióticos são comuns em todas essas regiões como: solo pobre, presença do fogo com ocorrência de queimadas periódicas e estação úmida e seca bem marcada (Goedert et al, 2008). No continente americano, o Cerrado brasileiro é a maior savana existente, tanto em biodiversidade, quanto em extensão territorial e é o segundo maior bioma brasileiro, se estendendo por $2.036 .448 \mathrm{~km} 2$, o que originalmente correspondia a $23 \%$ do território nacional (IBGE/MMA, 2004).

O Cerrado é considerado um hotspot de biodiversidade (Myers et al., 2000), por ser a savana tropical com o maior número de espécies do mundo. O bioma abriga cerca de 33\% da biodiversidade brasileira (Aguiar et al., 2004). Além da grande extensão, a sua localização central no continente é outro fator que contribui à elevada biodiversidade (Oliveira-Filho \& Fontes, 2000; Durigan, 2006). O bioma faz fronteira com os outros quatro biomas brasileiros: Mata Atlântica, Floresta Amazônica, Caatinga e Pantanal (IBGE/MMA, 2004), mas mais importante do que isso, a alta biodiversidade do Cerrado é resultado da ampla variedade de tipos fitofisionômicos que o compões (Machado et al., 2004). Existem muitos fatores responsáveis pelas formações destas fitofisionomias, tais como a profundidade do solo e o nível de umidade e fertilidade (Henriques, 2005), bem como a presença do fogo de origem natural, que também atua determinando o tipo de vegetação (Pivello, 2011), beneficiando as formações abertas (Miranda \& Sato, 2005), já que as plantas herbáceas sobrevivem mais aos incêndios e têm melhores taxas de reprodução após as queimadas.

Neste trabalho utilizaremos a classificação de Coutinho (1978), que definiu cinco tipos de fitofisionomias conforme um gradiente que se inicia com a completa ausência de arbustos e árvores e termina em um ambiente com dossel contínuo florestal: campo limpo, campo sujo, campo cerrado, cerrado sensu stricto e cerradão.

O Cerrado é ainda essencial na manutenção de muitas bacias hidrográfica do país, uma vez que as áreas de planalto frequentes favorecem o surgimento de nascentes e rios 
(Lima \& Silva, 2005). Além disso, a savana brasileira compreende ainda muitas regiões que são territórios de populações tradicionais, tendo grande valor na proteção do patrimônio cultural. Apesar disso, o Cerrado vem sofrendo degradação devido à conversão de áreas naturais em áreas agro-silvo-pastoris, o que tem levado à perda das espécies nativas mais sensíveis à modificação do ambiente.

No que se refere à diversidade de aves, o Cerrado possui 856 espécies com endemismo de 30 delas (Aguiar et al., 2004; Silva \& Santos, 2005). Essa riqueza representa metade de toda a avifauna presente no país. No entanto, 48 dessas espécies estão ameaçadas de extinção em algum nível (Marini \& Garcia, 2005) e o principal fator que ameaça as aves no Cerrado é a degradação dos ambientes naturais, principalmente devido à expansão da agricultura (Ratter et. al, 1997). Áreas de vegetação nativa vem sendo convertidas em pastagens com gramíneas exóticas que se tornam invasoras, plantações de Eucalipto e Pinus, bem como citricultura e monoculturas de cana-deaçúcar.

Quando consideramos os serviços ecossistêmicos prestados pelas aves sob uma perspectiva ecológica, Whelan, Sekercioglu e Wenny (2015) descreveram diversos tipos, tais como controle de pestes que atacam a agricultura e de animais vetores de doenças, como insetos e pequenos mamíferos. Além disso, o grupo das aves granívoras fazem o controle de sementes de plantas consideradas pragas de muitas culturas, mas existe também o desserviço de dispersão dessas sementes. O grande grupo funcional das aves frugívoras são responsáveis pela dispersão de sementes de muitas espécies nativas e assim contribuem com a regeneração natural. As espécies nectarívoras atuam na polinização de plantas nativas e também na polinização de culturas de importância econômica, aumentando a produtividade agrícola (Sekercioglu, 2012). Existem ainda serviços menos mencionados, mas de grande importância para a manutenção do funcionamento dos ecossistemas, como ciclagem de nutrientes, controle de presas e alimento de predadores na cadeia alimentar e remoção de lixo (Whelan, Sekercioglu \& Wenny, 2015).

No presente trabalho, desenvolvemos dois estudos para investigar a importância da conservação de diferentes áreas de Cerrado na manutenção de comunidades de aves nativas. No capítulo 1 nós utilizamos uma abordagem de rede biogeográfica e avaliamos os padrões de distribuição das aves em território nacional do Cerrado brasileiro. Para isso, respondemos a 4 perguntas:

- i) As áreas de Cerrado podem ser divididas em unidades biogeográficas distintas a partir da sua avifauna? 
- ii) Se sim, como essas unidades biogeográficas estão distribuídas?

- iii) A divisão tradicional entre Cerrado core e não-core pode explicar os padrões encontrados?

- iv) Quão importantes são as espécies de aves florestais na determinação desses módulos?

Com base nos resultados que tivemos no capítulo 1, nós pensamos no capítulo 2 , a fim de estudar em uma escala regional as áreas de Cerrado do estado de São Paulo. Apesar de não ser o maior bioma em extensão do estado, o Cerrado ocupava originalmente 18,2\% da área (Victor, 1975 apud Cavassan, 2002) e, atualmente, foi reduzido a apenas 1,13\% do estado (Cavassan, 2002), sendo que esse valor pode diminuir ainda mais com o crescimento da fronteira agrícola (Ratter et. al, 1997). Além disso, a vegetação nativa restante no estado de São Paulo vem sofrendo adensamento das fitofisionomias mais abertas, o que pode ameaçar a permanência das espécies de aves exclusivas de ambientes abertos.

Esse quadro de ameaça das áreas nativas de Cerrado na região Sudeste do Brasil é ainda mais agravado pela baixa proteção do bioma, já que apenas 8,2\% do Cerrado brasileiro encontra-se protegido por Unidades de Conservação, sendo a maior parte dessas de uso sustentável, ou seja, com menor grau de proteção (http://www.mma.gov.br/biomas/cerrado). Além disso, a maioria das áreas protegidas no Domínio do Cerrado dentro do estado de São Paulo compreende ambientes florestais, como matas de galeria e cerradão (Cavarzere et al., 2011), o que evidencia a situação crítica da biodiversidade exclusiva ou associada às fitofisionomias abertas. As fisionomias abertas do Cerrado, que normalmente possuem solo pobre e arenoso, menos viável para a agricultura, são facilmente convertidas em pastagem para pecuária intensiva, com a introdução de gramíneas exóticas, principalmente as braquiárias (Urochloa spp.) (Pivello, 2005). O resultado é um processo de invasão biológica em diversas áreas naturais de Cerrado, inclusive em unidades de conservação, causando perda de espécies da flora nativa e, consequentemente, da fauna associada a esses ambientes (Matos \& Pivello, 2009). As terras baratas de relevo suave do Cerrado também passaram a ser utilizadas, a partir da década de 1970, para silvicultura com espécies de Eucalyptus e Pinus (Pivello, s/d), levando à total alteração da estrutura desses ambientes originalmente abertos. 
Com base nesse cenário de ameaças ao bioma e à avifauna associada a ele, o Capítulo 2 foi guiado por 3 perguntas:

- i) Quão similares são as comunidades de aves diurnas em áreas de cerrado nativo e substituído?

- ii) Quais seriam os componentes determinantes de uma possível dissimilaridade?

- iii) Há diferença na riqueza biológica e funcional de aves diurnas entre áreas naturais de Cerrado com fisionomia aberta, com fisionomia fechada, Cerrado substituído por pastagem e por silvicultura de eucaliptos? 


\section{REFERÊNCIAS GERAIS}

Aguiar, L. M. S.; Machado, R. B. \& Marinho-Filho, J. A. (2004). Diversidade Biológica do Cerrado. In: Aguiar, L. M, S. \& Camargo, A. J. A. (2004). Cerrado: ecologia e caracterização. Embrapa, Brasília. 249p.

Cavarzere, V.; Moraes, g. p.; Dalbeto, a. c.; Maciel, F. G. \& Donatelli, R. J. (2011). Birds from cerradão woodland, an overlooked forest of the Cerrado region, Brazil. Pap. Avulsos Zool. (São Paulo), São Paulo, 51(17):259-274

Cavassan, O. (2002). O cerrado do Estado de São Paulo. In: KLEIN, A. L. (Org.).

Eugen Warming e o cerrado brasileiro - um século depois. 1 ed. São Paulo: Editora Unesp - Imprensa Oficial SP, 1:93-106.

Coutinho, L.M. (1978). O conceito de cerrado. Rev. Bras. Bot. 1(1):17-23.

Durigan, G. (2006). Observations on the southern cerrados and their relationship with the core area. In: Pennington, R. T., Lewis, G. P., \& Ratter, J. A. (Eds.) Neotropical savannas and dry forests: diversity, biogeography and conservation. CRC Press, Boca Raton, 67-77.

Durigan, G. \& Ratter, J. A. (2016). The need for a consistence fire policy for Cerrado conservation. Journal of Applied Ecology, 53:11-15.

Fidelis, A. \& Pivello, V. R. (2011). Deve-se usar o fogo como instrumento de manejo no Cerrado e Campos Sulinos? Biodiversidade Brasileira, 2:12-25.

Goedert, W. J.; Wagner, E.; Barcellos, A. O. (2008) Savanas tropicais: dimensão, histórico e perspectivas. In: Faleiro, F. G.; Farias-Neto, A. L. (Eds.). Savana: desafios e estratégias para o equilíbrio entre sociedade, agronegócio e recursos naturais. Planaltina - DF: Embrapa Cerrados, 49-77.

Henriques, R. P. B. (2005). Influência da história, solo e fogo na distribuição e dinâmica das fitofisionomias no bioma Cerrado. In: Scarlot, A.; Sousa-Silva, J. C. \& Felfili, J. M. (Orgs). Cerrado: ecologia, diversidade e conservação. Ministério do Meio Ambiente. Brasília: MMA, 439p. 
IBGE/MMA. (2004). Mapa de Biomas do Brasil - Primeira Aproximação. Disponível em:

http://geoftp.ibge.gov.br/informacoes_ambientais/vegetacao/mapas/brasil/biomas. pdf. Acesso em julho de 2018.

Lima, J. E. F. W. \& Silva, E. M. (2005) Estimativa da Produção hídrica superficial do Cerrado brasileiro. In: Sarlot, A.; Sousa-Silva, J. C. \& Felfili, J. M. (Orgs). Cerrado: ecologia, diversidade e conservação. Ministério do Meio Ambiente. Brasília: MMA, 439p.

Machado, R. B.; Ramos-Neto, M. B.; Pereira, P. G. P.; Caldas, E. F.; Gonçalves, D. A.; Santos, N. S.; Tabor, K. \& Steininger, M. (2004). Estimativas de perda da área do Cerrado brasileiro. Conservação Internacional, Brasília, DF. 26p.

Marini, M. A. \& Garcia, F. I. (2005). Conservação de aves no Brasil. Megadiversidade, 1(1):95-102.

Matos, D. M. S. \& Pivello, V. R. (2009). O impacto das plantas invasoras nos recursos naturais de ambientes terrestres: alguns casos brasileiros. Cienc. Cult. [online]. 61(1):27-30.

Ministério do Meio Ambiente. (2011). Plano de ação para prevenção e controle do desmatamento e das queimadas: cerrado. Brasília: MMA, 200p.

Mirada, H. S. \& Sato, M. N. (2005). Efeitos do fogo na vegetação lenhosa do Cerrado. In: Scarlot, A.; Sousa-Silva, J. C. \& Felfili, J. M. (Orgs). Cerrado: ecologia, diversidade e conservação. Ministério do Meio Ambiente. Brasília: MMA, 439.

Oliveira-Filho, A. T., \& Fontes, M. A. L. (2000). Patterns of floristic differentiation among Atlantic forests in Southeastern Brazil and the influence of climate. Biotropica, 32(4b), 793-810. https://doi.org/10.1111/j.1744-7429.2000.tb00619.x

Pivello, V.R. (2005). Manejo de fragmentos de cerrado: princípios para a conservação da biodiversidade. In: Scariot, A.; Sousa Silva, J. C. \& Felfili J. M. (Eds.). Cerrado: ecologia, biodiversidade e conservação. Ministério do Meio Ambiente, Brasília, DF. 402-413. 
Pivello, V. R. (2011). The Use of fire in the cerrado and Amazonian rainforests of Brazil. Fire Ecology, 7(1):24-39.

Ratter, J.A., Ribeiro, J.F. \& Bridgewater, S. (1997). The Brazilian cerrado vegetation and threats to its biodiversity. Ann. Bot. 80(3):223-230.

Sekercioglu, C.H. (2012). Bird functional diversity and ecosystem services in tropical forests, agroforests and agricultural areas. Journal of Ornithology, 153, pp. 153161. https://doi.org/10.1007/s10336-012-0869-4

Silva, J.M.C. \& Santos, M. P. D. (2005). A importância relativa dos processos biogeográficos na formação da avifauna do Cerrado e de outros biomas brasileiros. In A. Scariot, J.C. Sousa-Silva \& J.M. Felfili (eds.), Cerrado: ecologia, biodiversidade e conservação. Brasília: Ministério do Meio Ambiente, 219-233.

Simon, M. F. \& Penningtont, T. (2012). Evidence for adaptation to fire regimes in the tropical savannas of the brazilian cerrado. Int. J. Plant Sci. 173(6):711-723.

Solbrig, O. T. (1996). The Diversity of the Savanna Ecossystem. In: SOLBRIG, O. T.; MEDINA, E. \& SILVA, J. F. (Eds.) Biodiversity and Savanna Ecossystem Processes. Ed. Springer, 234.

Whelan, C. J.; Sekercioglu, C. H. \& Wenny, D. (2015). Why birds mather: from economic ornithology to ecosystem services. J. Ornithol., 156(1): 227-238. 


\section{CAPÍtUlo 1:}

\section{THE BIOGEOGRAPHIC NETWORK OF BIRDS IN THE BRAZILIAN CERRADO}

Autores: Lívia Petelincar De Sordi; Rochely Santos Morandini; Mariana Morais Vidal; Vânia Regina Pivello e José Carlos Motta-Junior. 


\section{The biogeographic network of birds in the Brazilian Cerrado}

Short running title: Bird biogeographic network in Cerrado

Lívia Petelincar De Sordi ${ }^{1}$; Rochely Santos Morandini ${ }^{1}$; Mariana Morais Vidal ${ }^{1}$; Vânia Regina Pivello ${ }^{1}$; José Carlos Motta-Junior ${ }^{1}$

${ }^{1}$ Department of Ecology, Instituto de Biociências, Universidade de São Paulo, Rua do Matão, Travessa 14, Cidade Universitária, 05508-090, São Paulo, SP, Brazil

\section{Corresponding author:}

Lívia Petelincar De Sordi: livia.sordi@usp.br

\section{Acknowledgements}

We are grateful to Dr. Leandro Reverberi Tambosi, Dr. Marco A. R. Mello, Dr. Pedro Ferreira Develey, and Dr. Cristina Yumi Miyaki for relevant suggestions. Lívia Petelincar De Sordi has a PhD scholarship funded by CAPES-Coordenação de Aperfeiçoamento de Pessoal de Nível Superior (88882.327899/2019-01). Mariana Morais Vidal was supported by FAPESP (2015/24802-4). Vânia R. Pivello receives financial support from CNPq-Conselho Nacional de Desenvolvimento Científico e Tecnológico (303970/20189).

\section{Biosketch}

Lívia Petelincar De Sordi is a biologist with great interest in Cerrado birds and their conservation. This paper is part of her PhD thesis at the University of São Paulo. Together with the other authors, she collaborates on issues related to bird diversity and conservation in this biodiversity hotspot.

Author contributions: LPDS, VRP, JCMJ, and RSM conceived the ideas; RSM collected the data; LPDS and MMV analysed the data; and LPDS led the writing with assistance from VRP, JCMJ, RSM, and MMV. 


\title{
The biogeographic network of birds in the Brazilian Cerrado
}

Lívia Petelincar De Sordi; Rochely Santos Morandini; Mariana Morais Vidal; Vânia Regina Pivello; José Carlos Motta-Junior

\begin{abstract}
Aim: Several scientific studies have separated the Brazilian Cerrado into core and marginal (non-core) areas, considering that the fauna and flora composition is undoubtedly different between these two areas. We aimed to identify biogeographical modules for Cerrado birds and to verify whether the core and marginal Cerrado zones exist that explain the distribution and diversity patterns found in this region.
\end{abstract}

Location: 42 sites in the Brazilian Cerrado

Taxon: Birds

Methods: We built two presence-absence matrices for birds over 42 sites in the Brazilian Cerrado and generated two biogeographic networks (with and without species typical of the Cerrado forest physiognomy). The second network was built to show the influence of forest/woodland physiognomies in the modules obtained. We analysed node degree and node-level metrics related to network modularity ( $\mathrm{c}$ and $\mathrm{z}$ indices) and the site categories when they were plotted in c-z space. Differences in these three node-level metrics were tested among the network modules, and between core and marginal areas.

Results: The network without Cerrado forest species showed no modularity, whereas the complete network produced three modules: Northwest, Centre-South, and Centre-North. Therefore, network modularity was mainly determined by forest bird species. Neither the distribution pattern nor the site species richness was explained by the dichotomy between the core and marginal Cerrado zones. The Northwest region was richer and had a greater number of regional species compared to that of the other two modules. Lower bird species richness was found in the Centre-South region, which had more widespread species.

Main conclusions: The biogeographic pattern for Cerrado birds perceived in this study did not evidence a clear dichotomy between core versus marginal regions in the Cerrado. Therefore, the same conservation effort should be implemented in the entire domain.

\section{KEYWORDS}

biogeographic regions, bird assembly, bird species distribution, savanna

\section{Introduction}


Birds are good indicators of biodiversity (Koskimies, 1989; Roché et al., 2010) as they embody high functional diversity and perform important ecological roles in maintaining ecosystem integrity, such as pollination, seed dispersal, and provision of food to fauna (Maas, Tscharntke, Saleh, Dwi Putra, \& Clough, 2015; Whelan, Sekercioglu \& Wenny, 2015). Studies on the patterns of biodiversity distribution are crucial to elucidate the diversification processes and biodiversity dispersion as well as threats to biodiversity, which aid in devising more efficient conservation strategies (Pimm et al., 2014). Therefore, an understanding of bird distribution patterns is essential to support managers of protected areas with regard to planning and implementation of conservation measures as well as for the establishment of new protected areas.

Traditionally, studies that compare the ecological structure of communities have used similarity indices and cluster analyses (e.g., Amaral, Munhoz, Walter, AguirreGutiérrez, \& Raes, 2017). Recently, a network approach was adopted to identify patterns of biogeographic distribution (Carstensen et al., 2012; Kougioumoutzis, Simaiakis, \& Tiniakou, 2014; Lenormand et al., 2019; Thébault, 2013; Vilhena \& Antonelli, 2015). Network analysis reveals any biodiversity compartmentalisation in a series of sites based on their species composition similarity (Barber, 2007; Newman \& Girvan, 2004).

There are two types of nodes in a biogeographic network: geographic units (sites) and species. A link between a site and a species indicates that the species occurs at that site (Carstensen et al., 2012). A highly linked subgroup of sites and species is defined as a module (Carstensen et al., 2013; Thébault, 2013). Thus, sites from the same module share more species than with sites from other modules (Carstensen et al., 2012). In this context, modules may be defined as groups of sites that share specific avifauna in terms of species identity (Carstensen \& Olesen, 2009). The network approach provides tools to quantify modularity, that is, the extent to which the network is organised in distinct groups or modules, and also permits the description of the role of each node in the modular network based on their linkage pattern (Carstensen et al., 2013; Guimerà \& Amaral, 2005; Olesen, Bascompte, Dupont, \& Jordano, 2007).

In the present study, we used a comprehensive database of bird species that occur in the areas of Brazilian territory covered by savanna vegetation (with different physiognomies) to build a biogeographical network for Cerrado birds. The Cerrado morphoclimatic domain - a geographic space with plateaus covered by savannas and 
grasslands, and penetrated by forest galleries -occupies a vast extension of the Brazilian territory of approximately 2,000,000 km² (Ab'Saber, 1967; Coutinho, 2016). Cerrado is the richest savanna in the world, exhibiting extremely high level of endemism (Forzza et al., 2012). However, half of the Cerrado area has been replaced by agriculture (MMA, 2015), which has adversely affected its natural biodiversity. These conditions have converted the Cerrado into a global biodiversity hotspot (Myers, Mittermeier, Mittermeier, da Fonseca, \& Kent, 2000).

The Cerrado is bordered by the Atlantic and the Amazon rainforests, and the semiarid Caatinga (Ab'Sáber, 2003), which influences its flora and fauna composition and may explain its extremely high biodiversity (Durigan, 2006; Oliveira-Filho \& Fontes, 2000). In previous studies, authors who described the Cerrado vegetation and environment (Ab’Saber, 1967; Eiten, 1972; Laboriau, 1966; Rizzini, 1963) discriminated it as a core zone (or central, nuclear) and a marginal zone. The core Cerrado zone is on the Brazilian Central Plateau, and the marginal zone borders the core zone, together with isolated savanna enclaves in other morphoclimatic domains, especially in the Amazonian region. The distinction between core and marginal zones has been assumed in most references to the Cerrado, although some studies have reported that floristic similarity between such zones does not support such classification (Ratter, Bridgewater, \& Ribeiro, 2003; Ratter, Bridgewater, \& Ribeiro, 2006). Regarding the Cerrado fauna, most studies on birds (Aguiar, Machado, \& Marinho-Filho, 2004; Pichorim, Silva, França, OliveiraJúnior, \& Rodrigues, 2014; Silva, 1995a; Silva, Fariñas, Felfili, \& Klink, 2006; Tubelis \& Cavalcanti, 2001) or other biological groups (e.g., Nóbrega \& De Marco, 2011) have been carried out in the core Cerrado, as the remaining marginal areas are usually considered as relatively less representative of the Cerrado bird biodiversity (Cardoso Da Silva \& Bates, 2002; Silva, 1995b; Silva, 1997). As an example, Silva \& Santos (2005) proposed the removal of two bird species (Neothraupis fasciata and Cypsnagra hirundinacea) to be classified as endemic to the Cerrado because they occur not only in the Cerrado core region but also in cerrado enclaves at the Amazonian biome.

As the avifauna in Brazil is highly diverse, widely distributed, and relatively wellknown, we selected this group to test the hypothesis of existing differentiated bird assemblages between the core and the marginal Cerrado areas, using the network approach. We identified biogeographic modules for the Cerrado birds and the patterns that determine them. Our main working questions were: i) Are there distinct 
biogeographic units of Cerrado sites that share specific avifauna? ii) If so, how are these biogeographic units distributed? iii) Is the traditional division of core and marginal Cerrado suitable to explain the patterns found? iv) How important are forest/ woodland birds in the structuring of Cerrado modules?

\section{Methods}

\subsection{Study areas}

This study comprised data from 42 sites with Cerrado vegetation in Brazil, obtained from the literature (Table S1 in Supporting Information). These sites were distributed throughout the Brazilian territory, and some are within the core Cerrado, while others are in marginal Cerrado areas (according to Ab'Saber, 1967) (Figure 1). The sites varied greatly in size, geomorphology, and protection status. Most of the sites were presumed to be effectively protected (those included in the category of integral protection, according to the Brazilian system of protected areas, SNUC (Brasil, 2000)), while others were not protected (Table S1). In addition, the sites were embedded in distinct matrices within natural or agricultural landscapes.

\subsection{Data}

Our data come from an extensive review by Morandini (2013) which we updated, and then comprised 50 bird surveys. Our database comprised 42 study areas covered by typical Cerrado physiognomies. To select the surveys, we adopted the following criteria: data collection covering all Cerrado physiognomies present in that area, and studies that combined more than one sampling method in order to minimise errors (e.g., active search, fixed points, transects, mist nets, and data from collections) (Table S1 in Supporting Information).

We built two presence-absence matrices (site versus bird species), which represented two biogeographic networks, both containing 42 sites. Because not all 50 surveys included aquatic species, we removed them from both matrices. In the second matrix, we also removed the species typical of forest/woodland physiognomies (i.e., cerradão, the woodland savanna, and riverine forests), and thus the second matrix 
contained species exclusively found in open Cerrado physiognomies (campo limpo, campo sujo, campo cerrado, and cerrado sensu stricto, following Coutinho (2002)). By comparing both matrices, we could verify the influence of forest/ woodland birds in the structuring of different modules.

Using Netcarto software (Guimerà \& Amaral, 2005) we analysed the network modularity and identified compartments, or modules. To evaluate the modularity significance of each matrix, we compared the observed modularity in our network with the modularity of 100 matrices generated by a null model that considered the number of links of both sites and species: null model 2 in Bascompte, Jordano, Melián, and Olesen (2003). Null models were developed using R software, version 3.4.0 (R Core Team, 2018).

We also used Netcarto software (Guimerà \& Amaral, 2005) to compute the number of links (degree) at each site to indicate the number of species (or richness). Using the same software, we also calculated two metrics that indicated the topological role of each site in the modular network: the among-module connectivity $(c)$ and the standardised within-module degree $(z)$. The metric $c$ reflected the connections with other modules, with higher $c$ values indicating the presence of widespread species belonging to different modules, as the site would have bird species evenly from all modules. In contrast, a higher $z$-metric value of a specific site indicated more bird species in common with the other sites of the same module (i.e., the presence of more local species) (Carstensen et al., 2012). In this way, we named sites according to their position in $c-z$ space (cut-off values of 2.5 for $c$ and 0.65 for $z$ ) (Olesen et al., 2007). The four possible categories of roles were: Peripheral: few local species and few widespread species; Connector: few local species and many widespread species; Module hub: many local species and few widespread species; and Network hub: many local species and many widespread species (Carstensen et al., 2012; Olesen et al., 2007).

We applied the Shapiro-Wilk normality test for the variables $c, z$, and degree; only the $z$-metric did not have a parametric distribution ( $\mathrm{W}=0.82399 ; \mathrm{p}=1.499 \mathrm{e}-05)$ (Table S2, in Supporting Information). To evaluate the differences among the modules concerning the metrics $c$ and degree, which presented normal distribution, we used an ANOVA test with Tukey's post-hoc tests. For metric $z$, we used the Kruskal-Wallis test with Dunn's nonparametric post-hoc tests. We also compared the values of $c, z$, and 
degree between core and marginal Cerrado areas using a Student's $t$-test for $c$ and degree, and a Mann-Whitney $U$ test for $z$. The critical significance level of 0.05 was adjusted to 0.0166 after applying the Bonferroni correction. We performed these statistical tests on $\mathrm{R}$ version 3.4.0 ( $\mathrm{R}$ Core Team, 2018).

As a final step, the 42 sites were located on a Brazil map, classified according to their modules following the first presence-absence matrix (all birds recorded in the 50 bird surveys except aquatic species, and all Cerrado physiognomies) using the software QGiz 2.18.25 (QGIS Development Team, 2017).

\section{Results}

The first biogeographic network, comprising species from both woodland and open Cerrado physiognomies, included 42 sampling sites and 971 bird species (Table S3 in Supporting Information). It was significantly modular $(\mathrm{M}=0.2063 ; \mathrm{p}<0.01)$, and bird species were grouped into three modules: Northwest (red), Centre-South (blue), and Centre-North (green) (Figure 1). There were no significant differences between the core and marginal regions for metrics $c, z$, and degree (Table 1). However, these three metrics differed among the modules (Table 2).

Table 1. Comparison between core and marginal Cerrado areas (according to Ab'Saber's classification, 1967) for the metrics $c, z$, and degree. The critical significance level of 0.05 corresponds to $p \leq 0.0166$ after Bonferroni correction, thus, no significant $p$ values were found.

\begin{tabular}{lccc}
\hline Variable & Test & Test value & p-value \\
\hline Degree & T test & -2.0996 & 0.045 \\
c & T test & -1.1502 & 0.259
\end{tabular}

$\begin{array}{lrrlll}\text { Table } & \mathbf{2 .} & \mathbf{z} & \text { Mann-Whitney } 211 & 0.830 & \begin{array}{l}\text { Degree, } c, \\ \text { metrics for } \\ \text { and }\end{array} \\ \text { the } & \text { tree } & & & & \begin{array}{l}\text { modules of } \\ \text { the }\end{array}\end{array}$


the Cerrado bird biogeographic network. The level of significance was 0.0166 after Bonferroni correction.

\begin{tabular}{ccccc}
\hline Module & $\begin{array}{c}\text { No. of } \\
\text { areas }\end{array}$ & $\begin{array}{c}\text { average Degree } \\
\text { (standard } \\
\text { deviation) }\end{array}$ & $\begin{array}{c}\text { average } \boldsymbol{c} \text { index } \\
\text { (standard deviation) }\end{array}$ & $\begin{array}{c}\text { average } z \text { index } \\
\text { (standard } \\
\text { deviation) }\end{array}$ \\
\hline $\begin{array}{c}\text { Northwest } \\
\text { Centre- }\end{array}$ & 5 & $378.2(43.68) * * *$ & $0.60(0.06)$ & $8.51(2.05) *$ \\
south & 22 & $224.32(57.14)$ & $0.40(0.09) * *$ & $3.78(1.00)$ \\
Centre- & 15 & $248.73(62.10)$ & $0.56(0.04)$ & $3.87(0.95)$ \\
north & & & & \\
\hline
\end{tabular}

*** ANOVA $=\mathrm{p}<0.001$, Tukey's post-hoc test $=$ for Northwest $/$ Centre-North, and Northwest $/$ CentreSouth $(\mathrm{p}<0.01)$

** ANOVA $=\mathrm{p}<0.001$, Tukey's post-hoc test $=$ for Centre-South $/$ Centre-North, and Centre-South / Northwest $(\mathrm{p}<0.01)$

* Kruskal-Wallis test $=\mathrm{p}<0.001$, Dunn's post-hoc test for Northwest / Centre-North $(\mathrm{p}=0.01)$, and Northwest / Centre-South $(\mathrm{p}<0.01)$

The Northwest module comprised five sites (Figure 1, red) and contained the three areas with the highest network degrees with 423, 417, and 377 species each, as species richness was indicated by the degree value. The Kruskal-Wallis and Dunn's tests revealed significant differences $(\mathrm{p}<0.01)$ between the Northwest module relative to the other two modules for both average degree (number of species in each module) and average $z$ index (related to the presence of local species) (Table 2). In other words, the Northwest module was the richest and had more local species than the Centre-South and Centre-North modules. The Centre-South module contained 22 sites (Figure 1, blue), and its $c$ index was significantly lower $(\mathrm{p}<0.01)$ compared with that of the other two modules (Table 2), indicating fewer widespread species. The Centre-North module comprised 15 sites (Figure 1, green).

a) 


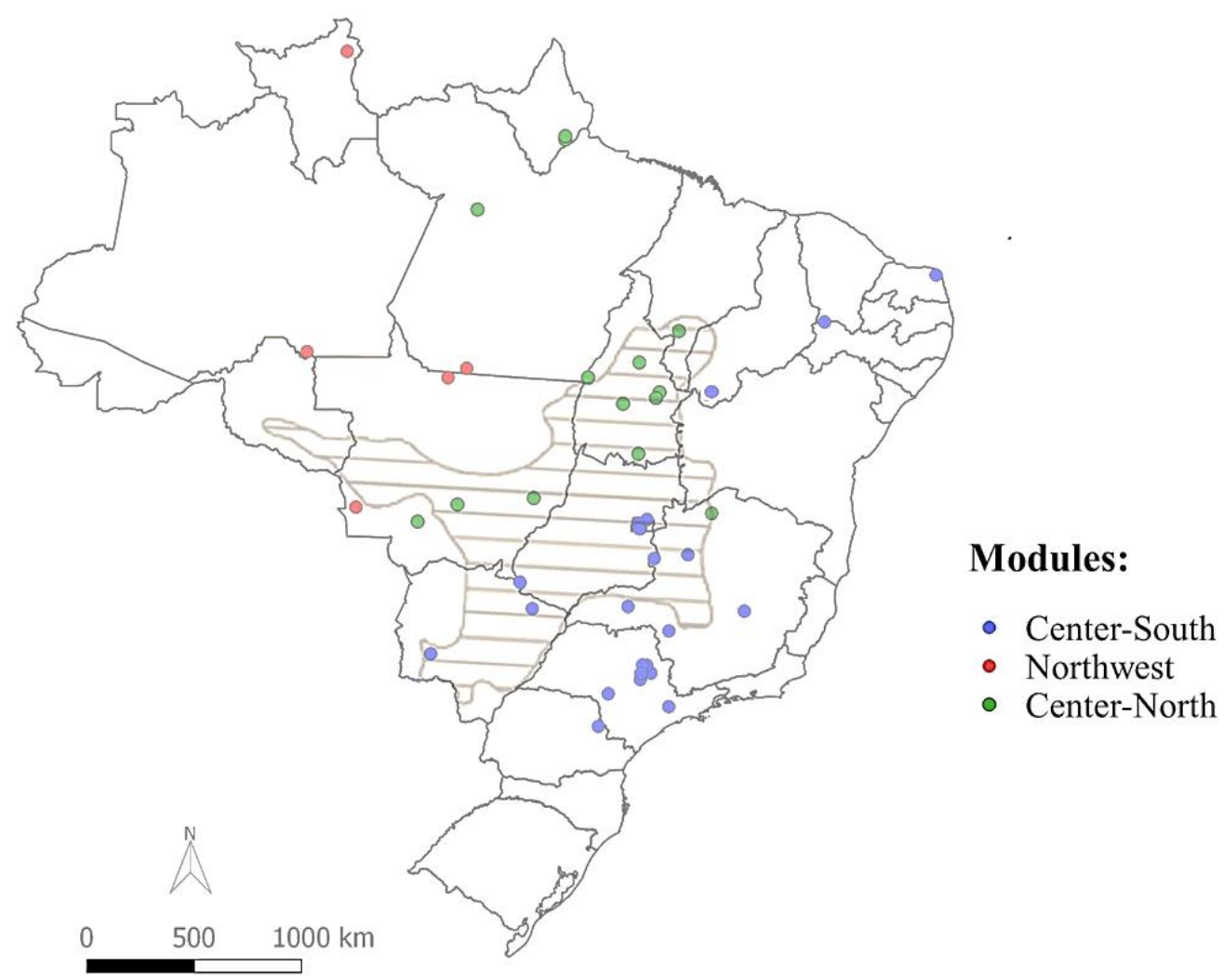

b)

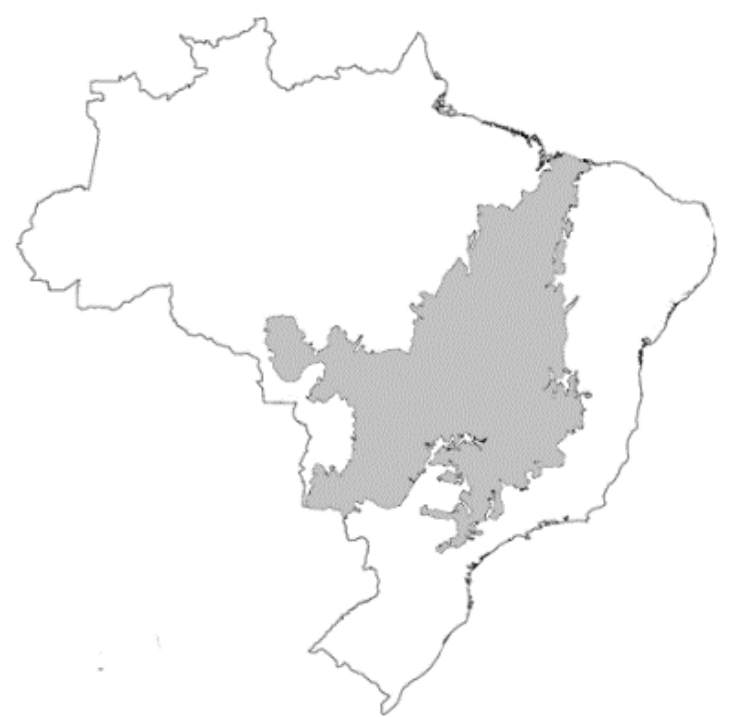

Figure 1. a) Distribution of the Cerrado bird sampling sites and their corresponding network modules: Centre-South (in blue), Northwest (in red), and Centre-North (in green). The hatched central area represents the core Cerrado according to Ab'Saber (1967). b) Modern Brazilian Cerrado map showing the Cerrado region in grey colour (According to IBGE/MMA, 2004). 
Classification of sites into topological roles in the biogeographic network indicated that the majority of the 42 sites $(86 \%)$ could be classified as Module hubs (Figure 2), that is, possessing many local species and a few widespread ones. This pattern was strongly followed by the Centre-South module (with $95 \%$ of the sites classified as Module hubs), yet these sites had the lowest among-module connectivity (c) and the Centre-North module (87\% of the sites defined as Module hubs). In contrast, only $40 \%$ of the Northwest module sites were classified as Module hubs and 60\% were defined as Network hubs (many local and many widespread species). Only two sites appeared as Peripheral (few local and few widespread species): one site in the Centre-South module and the other site in the Centre-North module. None of the 42 sites were classified as Connector (few local and many widespread species) (Figure 2).

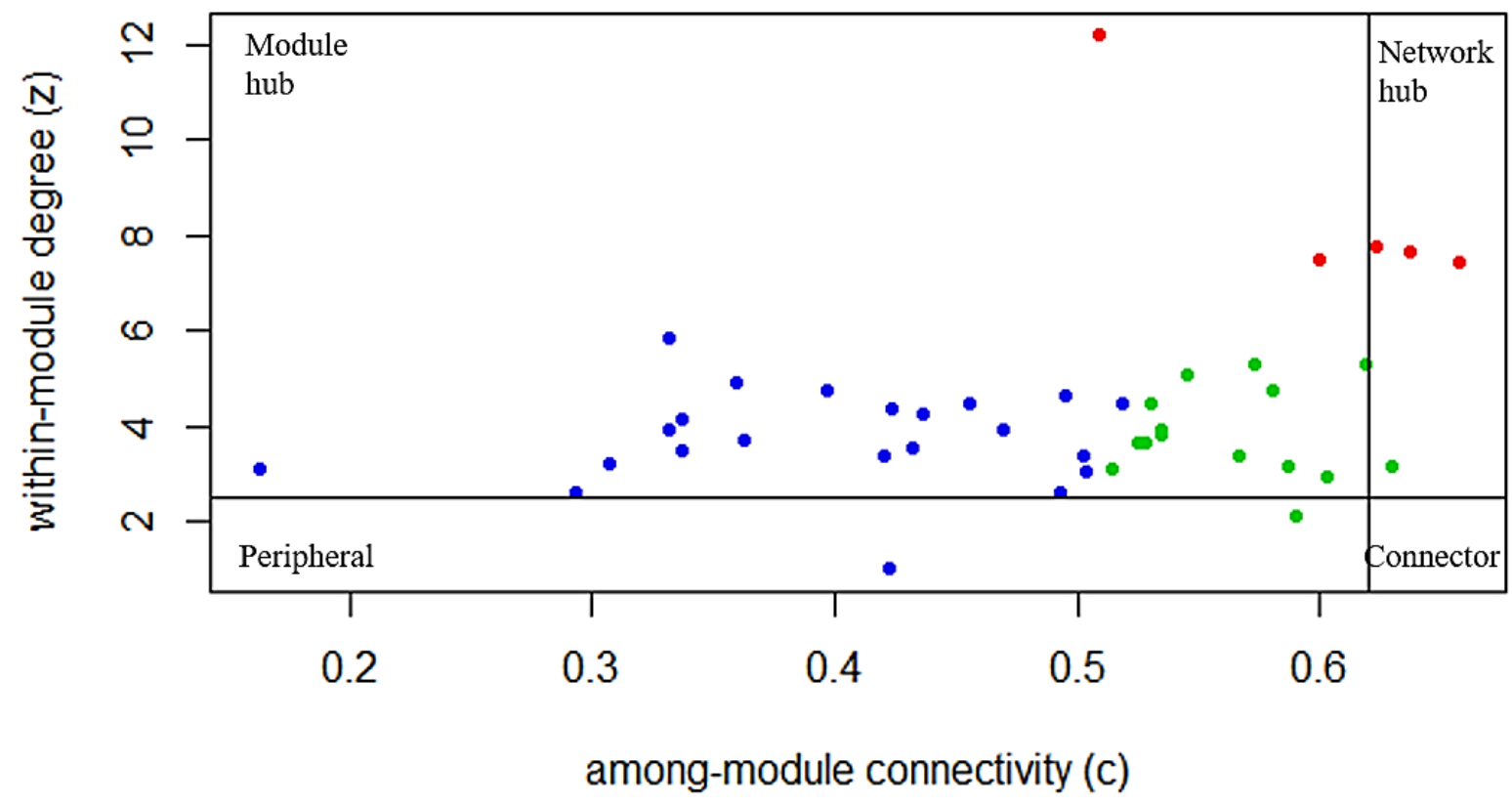

Figure 2. Distribution of sites in the modules Northwest (red), Centre-South (blue), and CentreNorth (green) according to their network role: Peripheral, Connector, Module hub, or Network hub.

The second network we built excluded all bird species that may use forest/ woodland physiognomies (cerradão, gallery and dry forests) and it was therefore composed only of open Cerrado bird species. This network contained a total of 95 species 
that occurred at the same 42 sites (Table S4 in Supporting Information). This second network did not reveal significant modularity $(\mathrm{p}=0.68)$.

\section{Discussion}

The three distinct biogeographical units found for Cerrado birds indicated an evident sectionalism regarding species distribution. However, bird richness (degree) and the proportion of widespread ( $c$ index) or local species $(z$ index) in the studied sites did not support the Cerrado classification as core and marginal. None of the modules corresponded to the core Cerrado. Further, the core Cerrado encompassed two of the three modules: Centre-North and Centre-South. All sites from the Northwest module would be considered marginal Cerrado, as well as 59\% ( $\mathrm{N}=13)$ of the sites from the Centre-South module.

Diverse factors probably influenced the distribution pattern revealed, such as geographical relief, climatic conditions, and geographic position in relation to the coast (continentality). In a recent study based on tree species composition of 588 sites distributed across the Cerrado, Françoso et al. (2020) identified seven floristic biogeographic districts in the Cerrado and correlated with climatic variables (temperature, precipitation, solar irradiation, and moisture). The authors clustered these seven districts into two major groups, distinguished mainly by the annual temperature. In the CentreNorth and Centre-South modules, we found that birds corresponded well to these two major groups of districts. Such consistency between bird diversity and the woody flora strengthens the idea that the Centre-South module is formed by sites that are strongly influenced by the Atlantic Forest. Moreover, the lowest among-module connectivity (c) obtained for this module highlights its regionality and its importance on keeping the regional bird diversity. Sano et al. (2019) proposed a division of the Cerrado into 19 ecoregions based on topography, vegetation, precipitation, and soil data. They used the most recent delimitation of Brazilian biomes, which in fact represent the Brazilian Morphoclimatic Domains according to Ab'Saber's definition $(1967,1977)$. According to the mapped information presented by Sano et al. (2019), the Centre-North and CentreSouth modules we found followed climatic and topographic conditions, distinguished by 
the limit of approximately 1,400 $\mathrm{mm}$ of annual precipitation and altitude of approximately $500 \mathrm{~m}$.

The Northwest module is mostly formed by enclaves of savanna vegetation in the Amazon Domain. These sites are distant and isolated from one another (ranging from $03^{\circ} 54^{\prime} 53^{\prime \prime} \mathrm{N}$ to $15^{\circ} 02^{\prime} 60^{\prime \prime} \mathrm{S}$ ). According to the Refuge Theory (Whitmore \& Prance, 1987), these sites correspond to relict areas from the Quaternary period, when climatic fluctuations produced alternating cycles of forest expansion in the warm-humid phases, and savanna expansion in the cold-dry phases. They are also related to specific conditions of very poor and sandy soils (Coutinho, 2016). In these patches, strongly influenced by the Amazon Forest, the avifauna represented a mix of species from the Cerrado and the Venezuelan Llanos, as well as other widespread South American species (Silva, 1997). The highest within-module degree $(z)$ for the Northwest module indicated that it contained more regional species not shared with the two other regional modules. Some examples of forest-dependent species that only occurred in the Northwest module and were well distributed within the sites are: Zimmerius gracilipes (Tyrannidae), Tinamus major (Tinamidae), Thamnomanes caesius (Thamnophilinae), Schiffornis turdina (Tityridae), Myrmotherula brachyura (Thamnophilidae), Galbula leucogastra (Galbulidae), Dendrocolaptes certhia (Dendrocolaptidae), and Cercomacra cinerascens (Thamnophilidae). Therefore, contrary to the idea that marginal Cerrado areas are species-impoverished and less important, the Amazonian savanna patches are composed of a large number of regional species and several widespread species, as shown by the high percentage of network hub sites in the Northwest module.

Our results provide strong evidence that the bird species occurring in forests are fundamental for establishing the modular pattern in the Cerrado biogeography. The three clear modules that emerge when all bird species were considered did not appear when bird species from forest physiognomies were excluded. The analysis presented here does not support the idea that the core Cerrado is richer than the marginal Cerrado, at least considering bird species. In line with this, Aguiar, Machado, and Marinho-Filho (2004) showed that bird species from the Atlantic and the Amazon forests cause considerable increment to the Cerrado avifauna, highlighting the importance of the marginal areas.

Given the high level of threat to the Cerrado and the perspective that $31 \%-34 \%$ of its remaining area (which is only $50 \%$ of what it was originally) will be replaced by 
other land uses by the year 2050 (Strassburg et al., 2017), efficient conservation actions for the Cerrado - throughout its entire territorial extension, in order to preserve maximum biodiversity - are crucial. Around 48 bird species found in the Cerrado are already threatened with extinction (Marini \& Garcia, 2005), mostly due to habitat loss and land degradation (MMA, 2015; Strassburg et al., 2017). The biogeographic patterns of Cerrado bird distribution revealed by the present study indicate that concentrating environmental protection measures only in the core Cerrado is a misleading strategy, as the great biodiversity of the marginal domain would be left aside. Furthermore, projections of global climate change effects indicate the possibility of migration of species from the central Cerrado (considered core) to the southeastern Cerrado (areas considered marginal) in the near future (Marini, Barbet-Massin, Lopes, \& Jiguet, 2009a). Therefore, it is essential to implement conservation efforts in the marginal patches of the Cerrado, such as areas in the southeast (Marini, Barbet-Massin, Lopes, \& Jiguet, 2009b) and the Amazonian savannas. Relevant information that reinforces the importance of the marginal Cerrado areas is highlighted by Durigan (2006), who observed that, despite representing less than $2 \%$ of the total Cerrado extension, its southern part constitutes more than $40 \%$ of its total floristic richness. In addition, it is important to consider the diverse roles played by each site for bird conservation, by both providing high species richness (Network hubs) and maintaining regional diversity (Module hubs). 


\section{References}

Ab’Saber, A. N. (1967). Domínios morfoclimáticos e províncias fitogeográficas do Brasil. Orientação (3): 45-48. Instituto de Geografia, Universidade de São Paulo. São Paulo.

Ab’Saber, A. N. (1977). Os domínios morfoclimáticos na América do Sul: primeira aproximação. Geomorfologia, São Paulo, 52, 1-22.

Ab’Sáber, A. N. (2003). Domínios de natureza no Brasil: potencialidades paisagísticas. São Paulo: Ateliê Editorial.

Aguiar, L. M. S., Machado, R. B., \& Marinho-Filho, J. A. (2004). Diversidade biológica do cerrado. In L. M. S. Aguiar \& A. J. A. Camargo, Cerrado: ecologia e caracterização. Brasília: Embrapa, 19-42.

Amaral, A. G., Munhoz, C. B. R., Walter, B. M. T., Aguirre-Gutiérrez, J., \& Raes, N. (2017). Richness pattern and phytogeography of the Cerrado herb-shrub flora and implications for conservation. Journal of Vegetation Science, 28(4), 848-858. https://doi.org/10.1111/jvs.12541

Barber, M. J. (2007). Modularity and community detection in bipartite networks. Physical Review. E, Statistical, Nonlinear, and Soft Matter Physics, 76 (6 Pt 2), 066102. https://doi.org/10.1103/PhysRevE.76.066102

Bascompte, J., Jordano, P., Melián, C. J., \& Olesen, J. M. (2003). The nested assembly of plant-animal mutualistic networks. Proceedings of the National Academy of Sciences of the United States of America, 100(16), 9383-9387. https://doi.org/10.1073/pnas.1633576100

Brasil. (2000). SNUC-Sistema Nacional de Unidades de Conservação; Lei 9.985 de 18 de julho de 2000. Ministério do Meio Ambiente.

Cardoso Da Silva, J. M. C., \& Bates, J. M. (2002). Biogeographic patterns and conservation in the South American Cerrado: A tropical Savanna hotspot. BioScience, 52(3), 225-233. $\quad$ http://doi.org/10.1641/00063568(2002)052[0225:BPACIT]2.0.CO;2 
Carstensen, D. W., Dalsgaard, B., Svenning, J., Rahbek, C., Fjeldså, J., Sutherland, W. J., \& Olesen, J. M. (2013). The functional biogeography of species: biogeographical species roles of birds in Wallacea and the West Indies. Ecography, 36(10), 10971105. https://doi.org/10.1111/j.1600-0587.2012.00223.x

Carstensen, D. W., \& Olesen, J. M. (2009). Wallacea and its nectarivorous birds: nestedness and modules. Journal of Biogeography, 36(8), 1540-1550. https://doi.org/10.1111/j.1365-2699.2009.02098.x

Carstensen, D. W., Dalsgaard, B., Svenning, J., Rahbek, C., Fjeldså, J., Sutherland, W. J., \& Olesen, J. M. (2012). Biogeographical modules and island roles: a comparison of Wallacea and the West Indies. Journal of Biogeography, 39(4), 739-749. https://doi.org/10.1111/j.1365-2699.2011.02628.x

Coutinho, L. M. (2002). O bioma Cerrado. In Klein, A. L. (org.) Eugene Warming e o cerrado brasileiro: um século depois, 77-92.

Coutinho, L. M. (2016). Biomas Brasileiros. São Paulo: Oficina de Textos.

Durigan, G. (2006). Observations on the southern cerrados and their relationship with the core area. In: Pennington, R. T., Lewis, G. P., \& Ratter, J. A. (eds) Neotropical savannas and dry forests: diversity, biogeography and conservation. CRC Press, Boca Raton, 67-77.

Eiten, G. (1972). The cerrado vegetation of Brazil. The Botanical Rewiew, New York, 38(2), 201-341.

Forzza, R. C., Baumgratz, J. F. A., Bicudo, C. E. M., Canhos, D. A. L., Carvalho, A. A., ... Zappi, D. C. (2012). New Brazilian Floristic List Highlights Conservation challenges. BioScience. BioScience, 62(1), 39-45. https://doi.org/10.1525/bio.2012.62.1.8

Françoso, R. D., Dexter, K. G., Machado, R. B., Pennington, R. T., Pinto, J. R. R., Brandão, R. A., \& Ratter, J. A. (2020). Delimiting floristic biogeographic districts in the Cerrado and assessing their conservation status. Biodiversity and Conservation, 29, 1477-1500. http://doi.org/10.1007/s10531-019-01819-3 
Guimerà, R., \& Amaral, L. A. (2005). Cartography of complex networks: modules and universal roles. Journal of statistical mechanics (Online), 2005(P02001), nihpa35573. https://doi.org/10.1088/1742-5468/2005/02/P02001

IBGE/MMA. (2004). Mapa de biomas do Brasil—primeira aproximação. Available in. https://www.ibge.gov.br/geociencias/informacoes-ambientais/15842biomas.html?edicao $=16060 \& \mathrm{t}=$ sobre Retrieved 15/01/2021

Koskimies, P. (1989). Birds as a tool in environmental monitoring. Annales Zoologici Fennici, 26, 153-166. https://www.jstor.org/stable/23734578

Kougioumoutzis, K., Simaiakis, S. M., \& Tiniakou, A. (2014). Network biogeographical analysis of the Central Aegean Archipelago. Journal of Biogeography, 41(10), 1848-1858. https://doi.org/10.1111/jbi.12342

Laboriau, L. C. (1966). Revisão da situação da ecologia vegetal nos cerrados. In Anais Simpósio sobre o cerrado, Academia Brasileira de Ciências, p. 5-38. 1966. Rio de Janeiro.

Lenormand, M., Papuga, G., Argagnon, O., Soubeyrand, M., De Barros, G., Alleaume, S., \& Luque, S. (2019). Biogeographical network analysis of plant species distribution in the Mediterranean region. Ecology and Evolution, 9(1), 237-250. https://doi.org/10.1002/ece3.4718

Maas, B., Tscharntke, T., Saleh, S., Dwi Putra, D., \& Clough, Y. (2015). Avian species identity drives predation success in tropical cacao agroforestry. Journal of Applied Ecology, 52(3), 735-743. https://doi.org/10.1111/1365-2664.12409

Marini, M. A., Barbet-Massin, M., Lopes, L. E., \& Jiguet, F. (2009a). Predicted climatedriven bird distribution changes and forecasted conservation conflicts in a Neotropical savanna. Conservation Biology, 23(6), 1558-1567. https://doi.org/10.1111/j.1523-1739.2009.01258.x

Marini, M. Â, Barbet-Massin, M., Lopes, L. E., \& Jiguet, F. (2009b). Major current and future gaps of Brazilian reserves to protect Neotropical savanna birds. Biological Conservation, 142(12), 3039-3050. https://doi.org/10.1016/j.biocon.2009.08.002 
Marini, M. A., \& Garcia, F. I. (2005). Conservação de aves no Brasil. Megadiversidade, $1(1), 95-102$.

MMA. (2015). Mapeamento do uso e Cobertura do Cerrado: projeto TerraClass Cerrado, 2013. p. 67. Brasília: Ministério do Meio Ambiente.

Morandini, R. (2013). Diversidade funcional das aves do Cerrado com simulações da perda de fisionomias campestres e de espécies ameaçadas: implicações para a conservação Dissertação de Mestrado. Institute of Biosciences. University of São Paulo.

Myers, N., Mittermeier, R. A., Mittermeier, C. G., da Fonseca, G. A. B., \& Kent, J. (2000). Biodiversity hotspots for conservation priorities. Nature, 403(6772), 853858. https://doi.org/10.1038/35002501

Newman, M. E. J., \& Girvan, M. (2004). Finding and evaluating community structure in networks. Physical Review E, 69(2), 026113_1-026113_5. https://journals.aps.org/pre/pdf/10.1103/PhysRevE.69.026113

Nóbrega, C. C., \& De Marco, P. (2011). Unprotecting the rare species: a niche-based gap analysis for odonates in a core Cerrado area. Diversity and Distributions, 17(3), 491-505. https://doi.org/10.1111/j.1472-4642.2011.00749.x

Olesen, J. M., Bascompte, J., Dupont, Y. L., \& Jordano, P. (2007). The modularity of pollination networks. Proceedings of the National Academy of Sciences of the United States of America, 104(50), 19891-19896. https://doi.org/10.1073/pnas.0706375104

Oliveira-Filho, A. T., \& Fontes, M. A. L. (2000). Patterns of floristic differentiation among Atlantic forests in Southeastern Brazil and the influence of climate. Biotropica, 32(4b), 793-810. https://doi.org/10.1111/j.1744-7429.2000.tb00619.x

Pichorim, M., Silva, M., França, B. R. A., Oliveira-Júnior, T. M., \& Rodrigues, M. C. (2014). A Cerrado bird community in the northernmost portion of northeastern Brazil-recommendations for conservation. Revista Brasileira de Ornitologia, 22(4), 347-362. https://doi.org/10.1007/BF03544272 
Pimm, S. L., Jenkins, C. N., Abell, R., Brooks, T. M., Gittleman, J. L., Joppa, L. N., Sexton, J. O. (2014). The biodiversity of species and their rates of extinction, distribution, and protection. Science, 344(6187), 1246752. https://doi.org/10.1126/science.1246752

QGIS Development Team. (2017). QGIS geographic information system developers manual. Open source geospatial foundation project. Electronic document. http://www.qgis.org Retrieved 12/7/2020

R Core Team. (2018). R: A language and environment for statistical computing. https://www.r-project.org Retrieved 12/1/2020. Vienna: R Foundation for Statistical Computing.

Ratter, A. J., Bridgewater, S., \& Ribeiro, J. F. (2006). Biodiversity patterns of the woody vegetation of the Brazilian Cerrado. In R. T. Pennington, G. P. Lewis \& J. A. Ratter, Neotropical savannas and seasonally dry forests: plant diversity, biogeography, and conservation, CRC Press.

Ratter, J. A., Bridgewater, S., \& Ribeiro, J. F. (2003). Analysis of the floristic composition of the Brazilian Cerrado vegetation III: Comparison of the woody vegetation of 376 areas. Edinburgh Journal of Botany, 60(1), 57-109. https://doi.org/10.1017/S0960428603000064

Rizzini, C. T. (1963). A flora do Cerrado: análise florística das savanas centrais. In M. G. Ferri (Coord.), Simpósio sobre os cerrados. São Paulo: Ed. Edgard Blücher/EDUSP (pp. 105-153).

Roché, J., Godinho, C., Rabaça, J. E., Frochot, B., Faivre, B., Mendes, A., \& Dias, P. C. (2010). Birds as bio-indicators and as tools to evaluate restoration measures. Conference: 7th European Conference on Ecological Restoration, At: Avignon, France (pp. 1-5).

Sano, E. E., Rodrigues, A. A., Martins, E. S., Bettiol, G. M., Bustamante, M. M. C., Bezerra, A. S., Bolfe, E. L. (2019). Cerrado ecoregions: A spatial framework to assess and prioritize Brazilian savanna environmental diversity for conservation. Journal of Environmental Management, 232(15), 818-828. https://doi.org/10.1016/j.jenvman.2018.11.108 
Silva, J. F., Fariñas, M. R., Felfili, J. M., \& Klink, C. A. (2006). Spatial Heterogeneity, land use and conservation in the cerrado region of Brazil. Journal of Biogeography, 33(3), 536-548. https://doi.org/10.1111/j.1365-2699.2005.01422.x

Silva, J. M. C. (1995a). Avian Inventory of the Cerrado Region, South America: implications for biological conservation. Bird Conservation International, 5(2-3), 15-28. https://doi.org/10.1017/S0959270900001052

Silva, J. M. C. (1995b). Biogeographic analysis of the South American Cerrado avifauna. Steenstrupia, 22, 46-67.

Silva, J. M. C. (1997). Endemic bird species and conservation in the Cerrado Region, South America. Biodiversity and Conservation, 6(3), 435-450. https://doi.org/10.1023/A:1018368809116

Silva, J.M.C. \& Santos, M. P. D. (2005). A importância relativa dos processos biogeográficos na formação da avifauna do Cerrado e de outros biomas brasileiros. In A. Scariot, J.C. Sousa-Silva \& J.M. Felfili (eds.), Cerrado: ecologia, biodiversidade e conservação. Brasília: Ministério do Meio Ambiente, 219-233.

Strassburg, B. B. N., Brooks, T., Feltran-Barbieri, R., Iribarrem, A., Crouzeilles, R., Loyola, R., Balmford, A. (2017). Moment of truth for the Cerrado hotspot. Nature Ecology and Evolution, 1(4), 99. https://doi.org/10.1038/s41559-017-0099

Thébault, E. (2013). Identifying compartments in presence-absence matrices and bipartite networks: insights into modularity measures. Journal of Biogeography, 40(4), 759768. https://doi.org/10.1111/jbi.12015

Tubelis, D. P., \& Cavalcanti, R. B. (2001). Community similarity and abundance of bird species in open habitats of a Central Brazilian Cerrado. Ornitologia Neotropica, 12, $57-73$.

Vilhena, D. A., \& Antonelli, A. (2015). A network approach for identifying and delimiting biogeographical regions. Nature Communications, 6(6848), 6848. https://doi.org/10.1038/ncomms7848

Whelan, C. J., C. H. Sekercioglu, and D. G. Wenny (2015). Bird ecosystem services: Economic ornithology for the $21^{\text {st }}$ century. In Why Birds Matter: Bird Ecosystem 
Function and Ecosystem Services (C. H. Sekercioglu, D. G. Wenny, and C. J. Whelan, Editors). University of Chicago Press, Chicago, IL, USA. In press.

Whitmore, T. C., \& Prance, G. T. (1987). Biogeography and Quaternary history in tropical America. Oxford UK: Clarendon Press. 


\section{CAPÍtulo 2:}

RIQUEZA E COMPOSIÇAO DA AVIFAUNA EM

AMBIENTES DE CERRADO NATIVO E ALTERADO
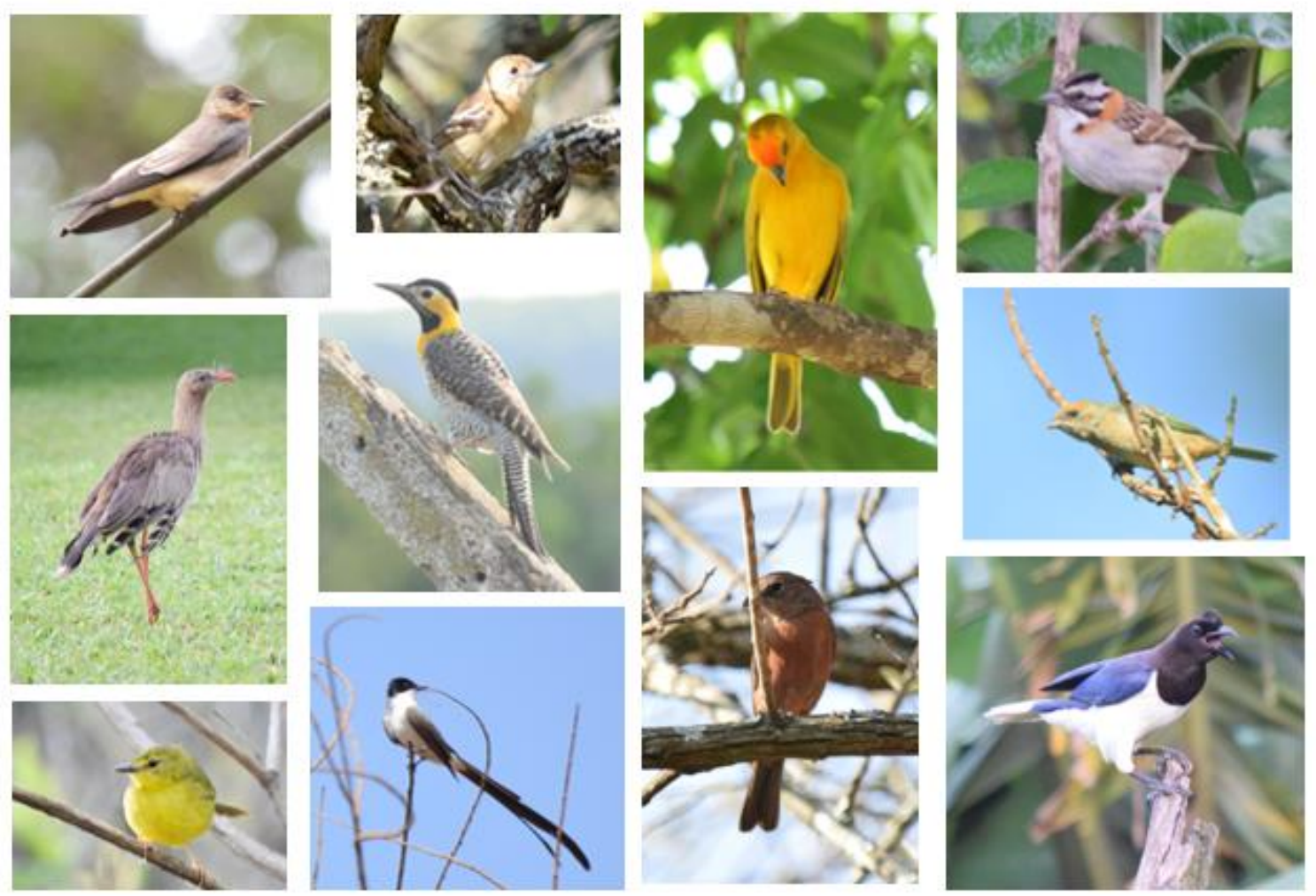

Autores: Lívia Petelincar De Sordi; José Carlos Motta-Jr; Renan Parmigiani e Vânia Regina Pivello. 
Riqueza e composição da avifauna em ambientes de cerrado nativo e alterado

Lívia Petelincar De Sordi ${ }^{1}$; José Carlos Motta-Jr ${ }^{1}$; Renan Parmigiani ${ }^{1}$ e Vânia Regina Pivello $^{1 .}$

${ }^{1}$ Departamento de Ecologia, , Instituto de Biociências, Universidade de São Paulo, Rua do Matão, Travessa 14, Cidade Universitária, 05508-090, São Paulo, SP, Brasil

\section{Autor de correspondência:}

Lívia Petelincar De Sordi: livia.sordi@usp.br

\section{Agradecimentos}

Agradecemos ao Dr. Leandro Reverberi Tambosi pelas importantes sugestões. Lívia Petelincar De Sordi recebeu apoio financeiro da Coordenação de Aperfeiçoamento de Pessoal de Nível Superior/ CAPES (88882.327899/2019-01). Vânia R. Pivello recebeu suporte financeiro do CNPq-Conselho Nacional de Desenvolvimento Científico e Tecnológico (303970/2018-9).

\section{Contribuições}

LPDS, VRP e JCMJ elaboraram as ideias; LPDS coletou os dados; LPDS e JCMJ identificaram os dados registrados, LPDS e RP fizeram a análise estatística e LPDS redigiu o texto com a orientação de VRP. 


\section{Riqueza e composição da avifauna em ambientes de Cerrado nativo e alterado}

Lívia Petelincar De Sordi; José Carlos Motta-Jr; Renan Parmigiani e Vânia Regina Pivello

\section{Resumo}

Contexto: Grande parte das áreas naturais de Cerrado no sudeste do Brasil foi convertida em pastagens com gramíneas exóticas ou silvicultura de eucaliptos. As áreas remanescentes de Cerrado nativo no estado de São Paulo têm sofrido adensamento da vegetação, o que vem afetando a biodiversidade e o funcionamento dos ecossistemas.

Objetivos: Esta pesquisa teve o objetivo de responder as seguintes perguntas: i) Quão similares são as comunidades de aves diurnas em áreas de cerrado nativo e substituído? ii) Quais seriam os componentes determinantes de uma possível dissimilaridade? iii) Há diferença nas riquezas biológica e funcional de aves diurnas entre fisionomia aberta de Cerrado, fisionomia fechada de Cerrado, pastagem e de silvicultura de eucaliptos?

Métodos: O estudo foi desenvolvido em quatro ambientes: cerrado aberto (campestre), cerrado fechado (cerrado sensu stricto e Cerradão), pastagem implantada e silvicultura de eucaliptos. As coletas foram replicadas espacialmente em três municípios do estado de São Paulo (Itirapina, Águas de Santa Bárbara e Santa Rita do Passa Quatro). Foram realizadas observações e escuta das aves em 104 pontos fixos, com registro fotográfico e sonoro, entre setembro e dezembro de 2017 e 2018.

Resultados: As quatro comunidades de aves apresentaram composições distintas. As áreas com vegetação nativa de Cerrado (com fisionomias abertas e fechadas), quando consideradas em conjunto, tiveram maior riqueza biológica de aves diurnas e mais espécies exclusivas do que as áreas alteradas juntas. A comunidade de aves do Eucalipto foi mais pobre do que todas as outras áreas em termos de riqueza biológica e funcional. As pastagens apresentaram, em geral, a maior riqueza funcional. O Cerrado aberto apresentou maior número de espécies exclusivamente campestres e as áreas de Cerrado fechado tiveram maior número de espécies essencialmente florestais.

Principais conclusões: Este estudo mostrou que tanto as fisionomias de Cerrado fechadas como as abertas abrigam uma diversidade específica de avifauna. Com base nisso, comprovamos a importância de se preservar ambas situações de Cerrado para a proteção das aves, que são consideradas pela literatura importantes provedoras de serviços ecossistêmicos. Além disso, mostramos que as áreas de Eucalipto não são permeáveis à avifauna, pois apresentaram baixa riqueza biológica e funcional. Por fim, reforçamos que é imprescindível que sejam mantidas áreas de proteção nas propriedades rurais, pois muitas das aves que frequentam as pastagens são dependentes de ambientes florestais nativos.

Palavras-chave: Avifauna; Comunidade de aves; Savana; Pastagem; Eucalipto; Riqueza funcional; Paisagem agrícola. 


\section{Introdução}

A análise da resiliência da biodiversidade nativa em paisagens agrícolas tem ganhado uma importância crescente, pois cada vez mais os remanescentes de vegetação natural vão sendo imersos em matrizes antrópicas (Campos, Charters \& Verdade, 2018). A grande maioria dos estudos sobre os impactos à fauna devidos à substituição da vegetação natural por outros usos foi realizada em ambientes de Mata Atlântica (Boesing, Nichols \& Metzger, 2018; Boesing et al., 2021), enquanto o Cerrado, que é considerado um hotspot de biodiversidade (Myers et al, 2000), fortemente ameaçado pela expansão das fronteiras agrícolas, permanece pouco estudado sob esse aspecto. A elevada riqueza biológica desse bioma é consequência de sua grande heterogeneidade espacial e fitofisionômica (Machado et al., 2004). De uma forma simplificada, Coutinho (1978) nomeou as cinco principais fisionomias do Cerrado, conforme um gradiente crescente de densidade de indivíduos lenhosos: campo limpo, campo sujo, campo cerrado, cerrado sensu stricto e cerradão. Essas fitofisionomias são determinadas pincipalmente por fatores abióticos, como a profundidade, fertilidade e umidade do solo (Henriques, 2005) e a presença do fogo (Simon \& Pennington, 2012, que representou uma forte pressão seletiva para o surgimento de diversas linhagens de plantas a ele adaptadas.

A avifauna do Cerrado apresenta riqueza elevada, com 856 espécies já registradas, sendo 30 delas consideradas endêmicas (Silva \& Santos, 2005). Apesar das aves terem muita mobilidade/dispersão, muitas espécies são sensíveis às alterações do habitat. Isso ocorre provavelmente devido à variação na diversidade de espécies de aves conforme a fitofisionomia, sendo que, provavelmente, os campos naturais e savanas abertas abrigam espécies endêmicas e ameaçadas que não utilizam as fisionomias fechadas (Willis, 1995; Willis, 2004). Espécies como o Alectrurus tricolor (Tyrannidae) e a Sporophila plumbea (Thraupidae) encontram-se ameaçadas de extinção, por serem exclusivas de ambientes abertos e se alimentarem apenas de gramíneas nativas, não permanecendo em áreas invadidas por gramíneas exóticas (Develey et al., 2005). Telles e Dias (2010) citam outros exemplos de aves exclusivas de ambientes abertos do Cerrado: Rhea americana (Rheidae), Culicivora caudacuta (Tyrannidae), Saltatricula atricollis (Thraupidae), Charitospiza eucosma (Thraupidae), Neothraupis fasciata (Thraupidae), Polystictus pectoralis (Tyrannidae). Esses autores defendem que a perda dos ambientes abertos provavelmente resultaria em perda dessa biodiversidade exclusiva. Batalha e colaboradores (2010) mostraram que a redução das áreas abertas do Cerrado pode 
acarretar em diminuição da diversidade funcional, o que ameaçaria o funcionamento dos ecossistemas. A conversão da vegetação natural em silvicultura - algo muito comum na região sudeste do Brasil - leva a uma simplificação da comunidade de avifauna (Millan et al. 2015).

Esta pesquisa teve o objetivo geral de avaliar os efeitos da conversão de fisionomias abertas de Cerrado em fisionomias fechadas (adensamento da vegetação) sobre a comunidade de aves diurnas, bem como da conversão de áreas naturais em áreas de pastagem com gramíneas exóticas e silvicultura de eucaliptos. Escolhemos as aves como grupo de interesse por serem amplamente distribuídas, bastante conhecidas pela ciência, relativamente fáceis de amostrar e boas bioindicadoras de qualidade de habitat, pois apresentam respostas rápidas às alterações do ambiente (Koskimies, 1989; Roché et al. 2010). Além disso, o grupo apresenta elevada diversidade funcional, exercendo funções ecológicas essenciais para a manutenção do ecossistema, tais como: polinização, dispersão de sementes, recurso alimentar para a fauna, controle populacional de presas e ciclagem de nutrientes (Maas et. al, 2015; Whelan et. al, 2015). Nesse sentido, a perda de diversidade funcional das aves pode resultar no empobrecimento dos atributos que as espécies apresentam, alterando a dinâmica e a estrutura do ecossistema (Tilman, 2001) e resultando na perda de serviços ecossitêmicos potenciais, como controle de pestes agrícolas e de ervas daninhas, limpeza de carcaças, controle de doenças, bem como serviço de lazer e turismo para atividade de observação de aves ("birdwathcing”) (Johnson et. al. 2010; Philpott et. al. 2009).

Partimos da hipótese de que cada diferente fitofisionomia natural de cerrado abriga uma diversidade de avifauna específica e que as comunidades de aves dos ambientes alterados são um subconjunto das comunidades dos ambientes naturais, devido à simplificação dos ecossitêmas das áreas alteradas pelo homem. Assim, buscamos então responder as seguintes perguntas: i) Quão similares são as comunidades de aves diurnas em áreas de cerrado nativo e substituído? ii) Quais seriam os componentes determinantes de uma possível dissimilaridade? iii) Há diferença na riqueza biológica e funcional de aves diurnas entre áreas naturais de Cerrado com fisionomia aberta, com fisionomia fechada, Cerrado substituído por pastagem e por silvicultura de eucaliptos?

\section{Métodos}




\section{Áreas de estudo}

Os dados foram coletados na região sudeste do Brasil, em três municípios do estado de São Paulo: Itirapina, Águas de Santa Bárbara e Santa Rita do Passa Quatro. Em cada município foram amostradas áreas de pastagem exótica (braquiárias, Urochloa spp.) e silvicultura de Eucalipto sem sub-bosque de regeneração natural, localizadas em propriedades particulares, após autorização dos proprietários das terras. Também amostramos áreas de vegetação natural com fisionomias abertas e fechadas de Cerrado no interior das unidades de conservação: Estação Ecológica de Itirapina, Estação Ecológica de Santa Bárbara e Parque Estadual de Vassununga - Gleba Pé-de-Gigante. Esta pesquisa foi aprovada pela Comissão Técnico-Científica do Instituto Florestal (COTEC - IF) pelo processo SMA nº 260108 - 004.938/2017.

- Estação Ecológica de Itirapina (EEI): Possui área total de 2.300 ha localizada nos municípios de Brotas e Itirapina (SP) (22 $2^{\circ} 11^{\prime} \mathrm{S}$ a $22^{\circ} 15^{\prime} \mathrm{S}$ e $47^{\circ} 51^{\prime} \mathrm{W}$ e $\left.48^{\circ} 00^{\prime} \mathrm{W}\right)$. Segundo o sistema de Köppen, o clima é Cwa, que se caracteriza por ser quente e úmido com inverno seco e temperatura média do mês mais frio pouco abaixo dos $18^{\circ} \mathrm{C}$ e a do mês mais quente ultrapassa os $22^{\circ} \mathrm{C}$. A EEI é composta por um mosaico de ambientes naturais, como campo limpo, campo úmido, campo sujo, campo cerrado, cerradão e floresta de galeria. As áreas do entorno da EEI são utilizadas principalmente para os usos agrícolas com pastagens cultivadas, cana-de-açúcar, citricultura e reflorestamentos com Eucaliptus spp. e Pinus spp. (Zanchetta, 2006).

- Estação Ecológica de Santa Bárbara (EESB): Possui área total de 2.712 ha e se localiza no município de Águas de Santa Bárbara (SP) (sede em 2248'59”'S e 49¹4'12”W). O clima corresponde ao Cwa, segundo a classificação de Köppen, com precipitação pluviométrica anual entre 1000 e $1300 \mathrm{~mm}$. A região da EESB era originalmente coberta por um mosaico de fisionomias de Cerrado e Floresta Estacional Semidecidual e atualmente preserva remanescentes de Cerrado com fisionomias campestres (campo úmido, campo cerrado) e savânicas (cerrado típico, cerrado denso e cerradão), além de florestas ribeirinhas e Estacional Semidecidual. A EESB faz contato, na maior parte de suas divisas, com pastagens para criação extensiva de gado e reflorestamentos comerciais de Eucaliptus spp. e Pinus spp. (Melo \& Durigan, 2009).

- Parque Estadual de Vassununga, gleba Pé-de-Gigante (PG): Possui área total

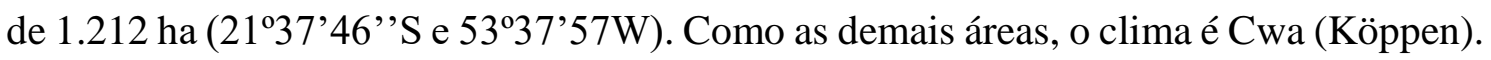


O PG é composto por um mosaico de ambientes naturais com Floresta Estacional Semidecidual e fitofisionomias de Cerrado: cerradão, cerrado sensu stricto e campo. A Zona de Amortecimento do PG é ocupada principalmente por plantio de cana-de-açúcar, reflorestamentos com Eucaliptus spp. e Pinus spp, citricultura e pastagens exóticas (Monteiro, 2009).

\section{Coleta de dados}

Realizamos escuta e observação de aves diurnas em 104 pontos, sendo 26 em cada tipo de ambiente: pastagem exótica, silvicultura de eucaliptos, fisionomias abertas de Cerrado (campo limpo, campo sujo ou campo cerrado) e fisionomias fechadas de Cerrado (cerrado sensu stricto ou cerradão) (Fig. 1), doravante chamados de Pastagem, Eucalipto, Cerrado Aberto e Cerrado Fechado. As observações em cada ponto tiveram duração de 10 min, totalizando 1040 minutos. Apesar de Vielliard et. al. (2010) terem definido 20 minutos como o tempo ideal para levantamentos na Mata Atlântica, Develey (2004) identificou que 10 min de observação em cada ponto fixo eram suficientes para a estabilização da curva de acumulação de espécies. As vocalizações nos pontos foram gravadas com um gravador digital Sony IC Recorder ICD-PX240 conectado a um microfone unidirecional Sennheiser. Além disso, quando possível, as aves foram fotografadas com uma câmera fotográfica Nikon D3300 com lente teleobjetiva de 70-300 mm. A localização dos pontos foi registrada com GPS Garmin eTrex20. Foi mantida a distância mínima de 200 m entre um ponto e outro, para evitar que indivíduos com vocalizações de longo alcance fossem escutados repetidamente em mais de um ponto (Vielliard et al., 2010). As observações foram realizadas em condições sem chuva e sem neblina intensa, no período da manhã (15 min após o nascer do sol até as $10 \mathrm{~h}$, ou $11 \mathrm{~h}$ no horário de verão) e no período da tarde (das 15:00 h até o pôr do sol), que correspondem aos momentos de maior atividade das aves diurnas.

Coletamos os dados entre setembro e novembro de 2017 e outubro e dezembro de 2018. Esses meses foram escolhidos porque compreendem o período reprodutivo da maior parte das espécies de aves que habitam a região, sendo a época em que estas apresentam maior atividade e são mais facilmente localizadas (Motta-Junior et. al., 2008; Vielliard et. al., 2010). 
a)

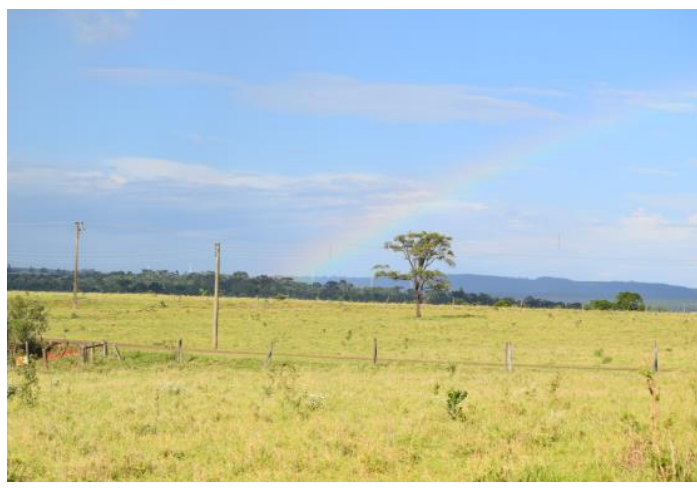

c)

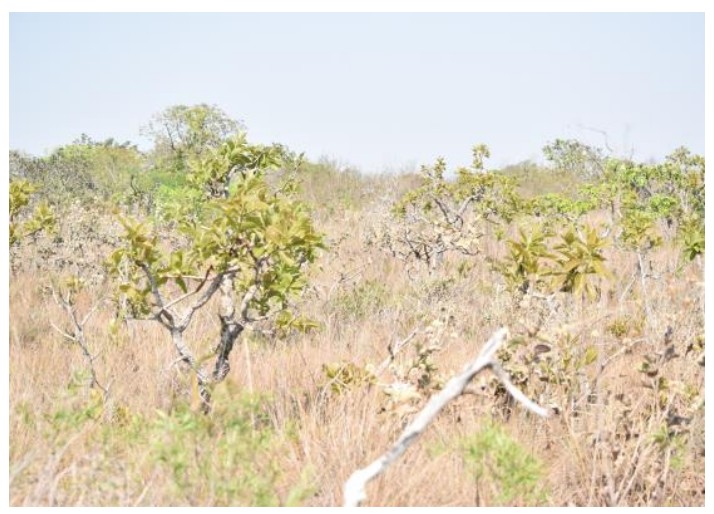

b)

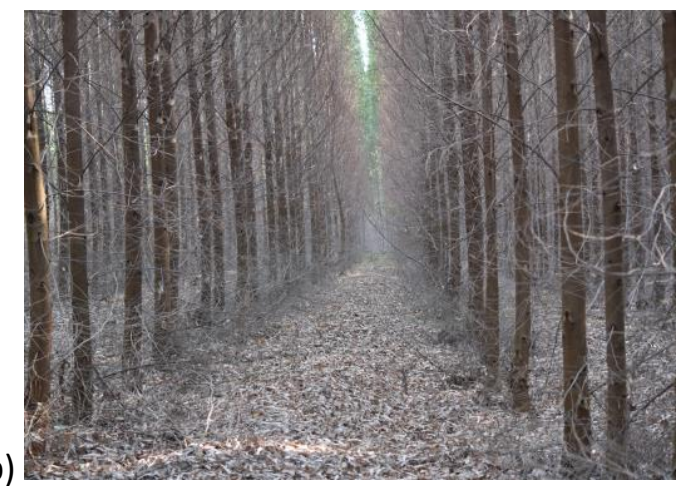

d)

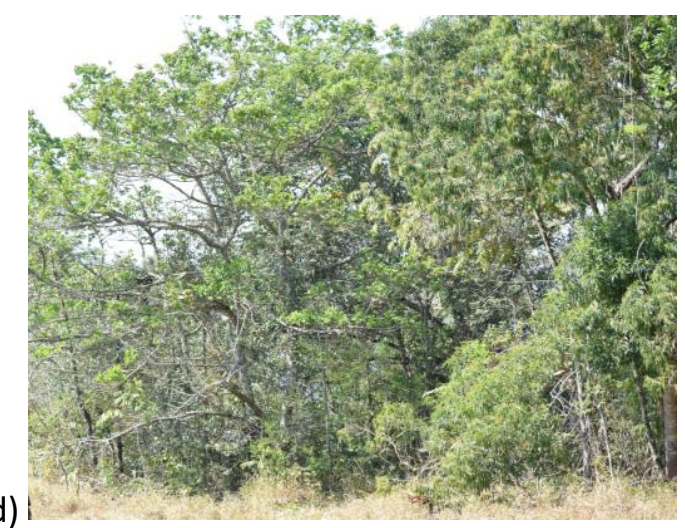

Figura 1: Ambientes analisados: a) Pastagem com gramíneas exóticas; b) Silvicultura de Eucalipto sem regeneração natural; c) Cerrado com fisionomia aberta; d) Cerrado com fisionomia fechada.

\section{Análise dos dados}

As aves observadas e fotografadas foram identificadas com o uso dos guias Aves: Estado de São Paulo (Endrigo, 2010), Aves do Brasil: Pantanal e Cerrado (Gwynne et. al, 2011), e do site Wiki Aves (http://www.wikiaves.com.br/), bem como consultas a ornitólogos especialistas. Para a identificação das vocalizações gravadas foi utilizado o site xeno-canto (http://www.xeno-canto.org), juntamente com a participação de um especialista em avifauna do Cerrado paulista (o segundo autor deste trabalho).

Organizamos os dados em uma matriz de ocorrência de espécies por ponto amostral. Os levantamentos nos diferentes anos e diferentes cidades foram somados e considerados em conjunto, para que houvesse uma quantidade significativa de amostras 
em cada ambiente. Produzimos então as curvas de acumulação de espécies para cada ambiente, a fim de avaliar a suficiência amostral. A partir dessa mesma matriz de espécies registradas por ponto amostral, fizemos o dendrograma de similaridade para avaliar a similaridade das comunidades de aves utilizando o Índice de Jaccard. Utilizamos o software PAST, versão 2.17 (Hammer; Harper \& Ryan, 2001) para elaborar o dendrograma.

Calculamos os índices de riqueza biológica (número de espécies registradas) e funcional para cada ambiente. A riqueza funcional das comunidades foi calculada a partir da matriz com as características funcionais de cada espécie (Tab. S1), produzida por Morandini (2013). Os traços funcionais utilizados foram: massa, dieta (vertebrado; invertebrado; folha; frutos/sementes; grãos; flores; néctar), local de forrageio (água; solo úmido/encharcado; solo seco; vegetação; ar), estratégia de forrageio (procura/persegue; recolhe; espera/investe; bica; pasta; vasculha/cava) e local de nidificação (cavidade/fenda/oco; topo/extremidade; ramos; suspenso; apêndices vegetais; vegetação palustre; cupinzeiro; paredão/barranco; ninhos desocupados; ninhos ativos de outra espécie; solo; próximo à água; edificações humanas). Cada espécie poderia apresentar mais de um item para cada traço funcional, com exceção da massa. Atribuímos aos dados os valores $1=$ presente ou $0=$ ausente, para cada item do traço funcional. A partir das matrizes de traços e de ocorrência de espécies por ponto amostral, calculamos o Índice de Riqueza Funcional (FRic - functional richness), conforme descrito por Villéger et al (2008). O FRic indica o espaço funcional total preenchido pela comunidade de um determinado ambiente e é calculado a partir do hipervolume ocupado pelas espécies da comunidade conforme seus traços funcionais (Villéger et al, 2008). Calculamos a riqueza funcional (FRic) multivariada e a FRic por traço. A FRic multivariada é estimada pelo volume do polígono convexo preenchido pela comunidade; já a FRic por traço é estimada como a diferença entre o valor máximo e o mínimo daquele traço na comunidade, ou seja, indica a amplitude do traço na comunidade (Mason et al., 2005). Escolhemos esses índices por avaliarem satisfatoriamente a amplitude de cada traço funcional na comunidade e por não utilizarem os valores de abundância. Nós utilizamos o teste ANOVA juntamente com o teste pós-hoc de Tukey para avaliar se houve diferença significativa entre os quatro ambientes com relação aos índices calculados. Esses cálculos foram realizados usando o software R, versão 3.4.0 (R Core Team, 2017). 
Por fim, nós usamos o teste qui-quadrado com nível de significância de 0,05 para avaliar a relação entre a composição das comunidades de cada ambiente: Cerrado aberto, Cerrado fechado, Pastagem e eucalipto e a classificação do habitat usado pelas espécies (conforme Motta-Júnior et al., 2008). De acordo com essa classificação, as espécies podem ser: $\mathrm{C} 1$ : Estritamente campestre, ou seja, que utilizam ambientes abertos; $\mathrm{C} 2$ : essencialmente campestres, ou seja, que preferem ambientes abertos, mas também utilizam ambientes florestais. F1: Estritamente florestal, ou seja, que utiliza apenas ambientes florestais; e F2: Essencialmente florestais, que preferem ambientes florestais, mas pode utilizar áreas campestres.

\section{Resultados}

As curvas de acumulação de espécies obtidas para os quatro ambientes (Fig. 2) apontaram uma forte tendência à estabilização, indicando que o esforço amostral provavelmente foi suficiente para caracterizar as comunidades. Foram amostradas 119 espécies, pertencentes a 39 famílias, considerando todos os municípios e ambientes (Tabela S2). No total, o grupo mais representado foi dos Passeriformes, com 78 espécies. O total de espécies registrado para cada ambiente foi: Eucalipto $=27 ;$ Pastagem $=68$; Cerrado aberto $=69$ e Cerrado fechado $=64$.

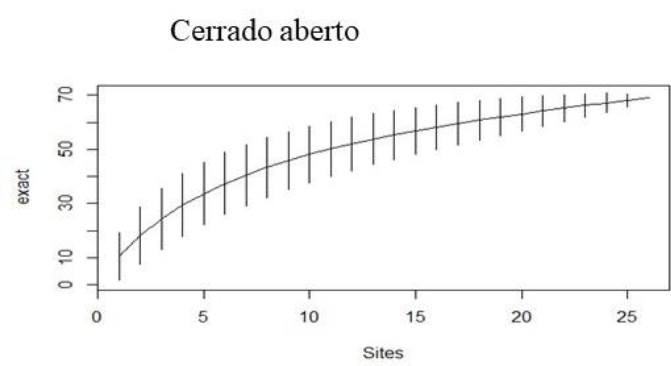

Pastagem

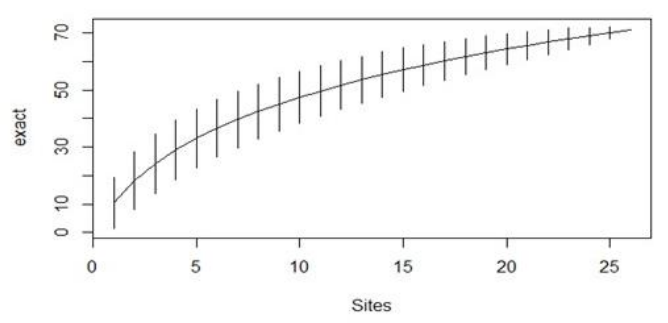

Cerrado fechado

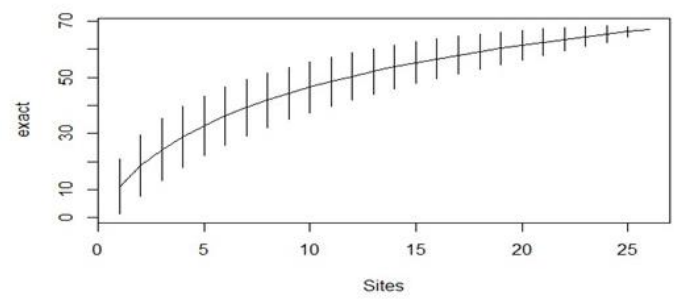

Eucalipto

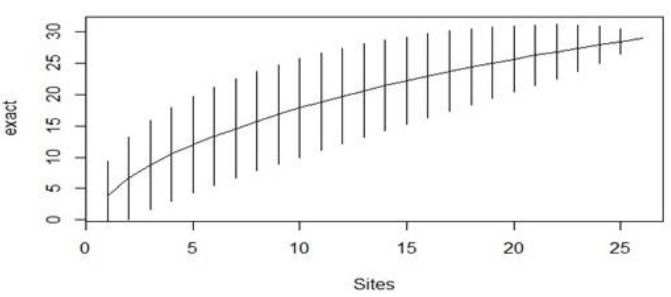


Figura 2. Curvas de acumulação de espécies por número de pontos de coleta para os quatro ambientes amostrados: Cerrado aberto, Cerrado fechado, Pastagem e Eucalipto.

Com relação à composição das comunidades de cada ambiente, as espécies mais frequentes, ou seja, presentes em mais do que 11 pontos (>10\%) foram: no Eucalipto: Turdus leucomelas, Zonotrichia capensis e Patagioenas picazuro; na Pastagem: Vanellus chilensis, Patagioenas picazuro, Zonotrichia capensis, Tangara sayaca, Pitangus sulphuratus, Tyrannus savana e Troglodytes musculus; no Cerrado aberto: Crypturellus parvirostris, Elaenia flavogaster e Elaenia chiriquensis; e no Cerrado fechado: Elaenia flavogaster, Turdus leucomelas, Tangara sayaca, Tangara cayana, Myiothlypis flaveola e Patagioenas picazuro.

Com exceção do Eucalipto, os outros três ambientes tiveram espécies exclusivas, ou seja, espécies que só foram registradas naquele ambiente (Tabela 1).

\begin{tabular}{|c|c|c|c|}
\hline Pasto & Cerrado fechado & Cerrado aberto & Cerrado aberto e fechado \\
\hline Vanellus chilensis 13 & Synallaxis frontalis 3 & Zenaida auriculata 9 & Crypturellus parvirostris \\
\hline Sicalis flaveola 10 & Cnemotriccus fuscatus 3 & Saltatricula atricollis 7 & Tapera naevia \\
\hline Guira guira 6 & Arremon flavirostris 2 & Emberizoides herbicola 5 & Nystalus chacuru \\
\hline Pygochelidon cyanoleuca 6 & Amazilia lactea 2 & Melanopareia torquata 3 & Thamnophilus pelzelni \\
\hline Theristicus caudatus 3 & Coryphospingus cucullatus 2 & Mustelirallus albicollis 2 & Hemitriccus margaritaceiventer \\
\hline Tersina viridis 3 & Myiarchus ferox 2 & Geranoaetus albicaudatus 1 & Elaenia obscura \\
\hline Athene cunicularia 3 & Galbula ruficauda 1 & Myiophobus fasciatus 1 & Phaeomyias murina \\
\hline Volatinia jacarina 3 & Turdus rufiventris 1 & Elaenia mesoleuca 1 & Ramphocelus carbo \\
\hline Syrigma sibilatrix 2 & Piranga flava 1 & Gubernetes yetapa 1 & Cypsnagra hirundinacea \\
\hline Caracara plancus 2 & Patagioenas cayennensis 1 & Chaetura meridionalis 1 & Hylocharis chrysura \\
\hline Machetornis rixosa 2 & Chlorostilbon lucidus 1 & Schistochlamys ruficapillus 1 & Synallaxis albescens \\
\hline Sporophila lineola 2 & Herpsilochymus longirostris 1 & Formicivora rufa 1 & Coereba flaveola \\
\hline Myiozetetes similis 2 & Colaptes melanochloros 1 & Neothraupis fasciata 1 & Myiarchus swainsoni \\
\hline Fluvicola nengeta 2 & Picumnus albosquamatus 1 & Dacnis cayana 1 & Setophaga pitiayumi \\
\hline Colonia colonus 2 & Empidonomus varius 1 & & \\
\hline Amazona aestiva 2 & Lathrotriccus euleri 1 & & \\
\hline Ictinia plumbea 1 & Taraba major 1 & & \\
\hline \multicolumn{4}{|l|}{ Tolmomyias sulphurescens 1} \\
\hline \multicolumn{4}{|l|}{ Nothura maculosa 1} \\
\hline \multicolumn{4}{|l|}{ Herpetotheres cachinnans 1} \\
\hline \multicolumn{4}{|l|}{ Jacana jacana 1} \\
\hline \multicolumn{4}{|l|}{ Tangara palmarum 1} \\
\hline \multicolumn{4}{|l|}{ Forpus xanthopterygius 1} \\
\hline \multicolumn{4}{|l|}{ Synallaxis spixi 1} \\
\hline Xolmis cinereus 1 & & & \\
\hline
\end{tabular}


Tabela 1: Lista das espécies registradas em apenas um ambiente (Pastagem, Cerrado aberto ou Cerrado fechado) e das espécies que apareceram na intersecção do Cerrado aberto com Cerrado fechado. O número à frente do nome da espécie não representa abundância, mas sim o número de pontos amostrais em que a espécie esteve presente.

O dendrograma de similaridade demonstrou que os quatro ambientes possuem comunidades de aves bastante específicas e diferentes entre si (Fig. 3). É possível observar ainda que há uma maior similaridade entre Eucalipto e cerrado fechado e entre Pastagem e cerrado aberto, considerando o índice de similaridade de Jaccard. 


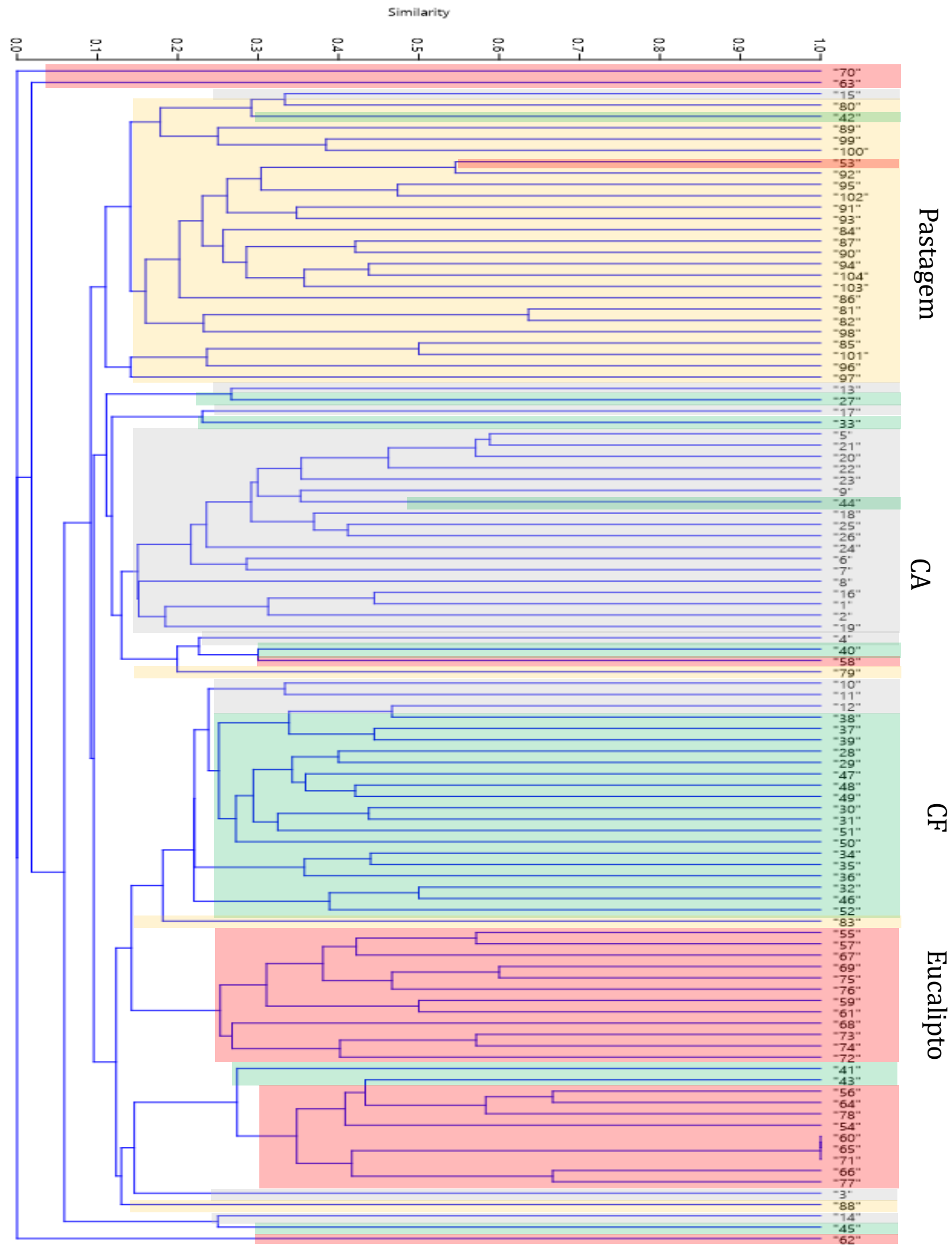

Figura 3: Dendrograma de similaridade elaborada a partir de matriz com presença de espécies por ponto amostral, utilizando-se o Índice de Jaccard. Os diferentes ambientes de coleta estão representados pelas cores: amarelo: pastagem; cinza: cerrado aberto; verde: cerrado fechado; vermelho: Eucalipto. 
A comparação entre a composição de espécies nas comunidades dos quatro ambientes e a classificação dos habitats utilizados por elas (de acordo com Motta-Júnior et al, 2008) mostra, a partir do teste qui-quadrado, que o Cerrado aberto possui significativamente mais espécies estritamente campestres (C1) do que o esperado. Enquanto o Cerrado fechado possui um número significativamente maior de espécies essencialmente florestais (F2) do que o esperado (Tabela 2).

Tabela 2: Resultado do teste qui-quadrado para a composição dos habitats das espécies presentes em cada ambiente: CA: Cerrado aberto; CF Cerrado fechado; Pa: Pastagem; Eu: Eucalipto. Classificação realizada por MottaJúnior: C1: estritamente campestre; C2: Essencialmente campestre; F1: estritamente florestal; F2: essencialmente florestal.

\begin{tabular}{ccccc}
\hline & C1 & C2 & F1 & F2 \\
\hline CA & $29,759^{*}$ & 2,113 & 2,715 & 3,422 \\
CF & 16,539 & 2,745 & 6,194 & $23,391^{*}$ \\
Pa & 0,248 & 5,977 & 0,39 & 12,904 \\
Eu & 9,345 & 1,592 & 0,209 & 0,571 \\
\hline Nível de significância= 0,05 & para 9 graus & de liberdade, então valor
\end{tabular}
adotado de $\mathrm{X}^{2}=16,919$

Quanto à riqueza biológica, o Eucalipto possui significativamente menos espécies que os outros três ambientes - Cerrado aberto, Cerrado fechado e Pastagem - que não diferiram entre si (Fig. 5a; Tab. S3), sendo também o ambiente com menor riqueza funcional total. A Pastagem foi o ambiente com maior riqueza funcional total, sendo que Cerrado aberto e Cerrado fechado não apresentaram diferença entre si (Fig. 5b).

Observando-se os valores de riqueza funcional para cada traço isoladamente, temse que o pasto teve maior riqueza de massa do que o Eucalipto, enquanto que os demais ambientes não diferiram entre si (Fig. 5c). Com relação à dieta das aves, a comunidade da Pastagem foi mais rica em itens alimentares do que as comunidades do Cerrado aberto e do Eucalipto, enquanto que a comunidade do Cerrado fechado foi mais rica em dieta do que a do Eucalipto (Fig. 5d). Quanto à estratégia de forrageio, a avifauna presente na Pastagem apresentou maior riqueza do que aquelas presentes nos outros três ambientes, sendo as estratégias de forrageio das aves do Eucalipto muito pouco diversificadas (Fig. 
5e). O último item funcional avaliado foi o local de nidificação, em que a Pastagem foi mais rica do que os outros três ambientes, e o Eucalipto o ambiente mais pobre de todos (Fig. 5f). 
a) Riqueza biológica

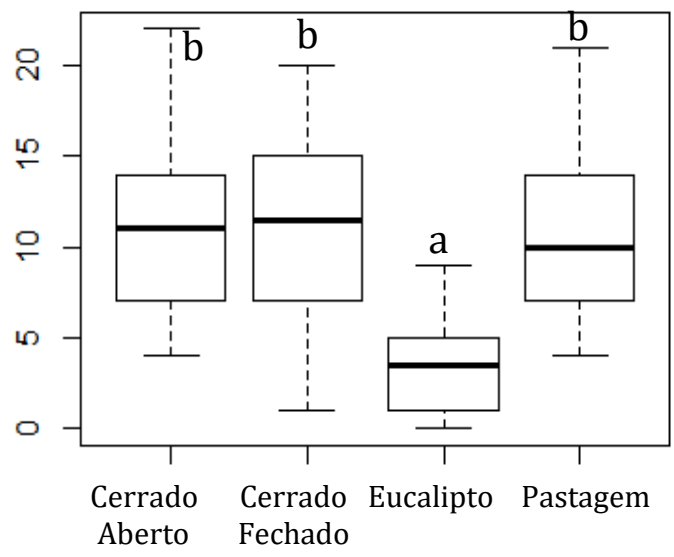

c) Riqueza funcional - Massa

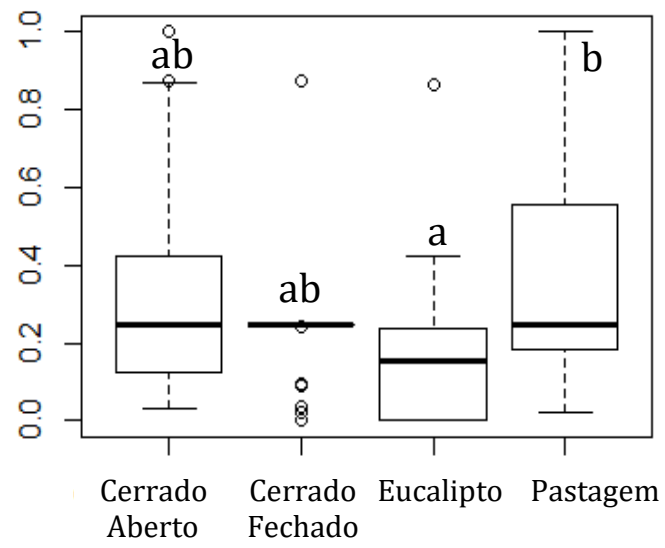

e) Riqueza funcional Estratégia de forrageio

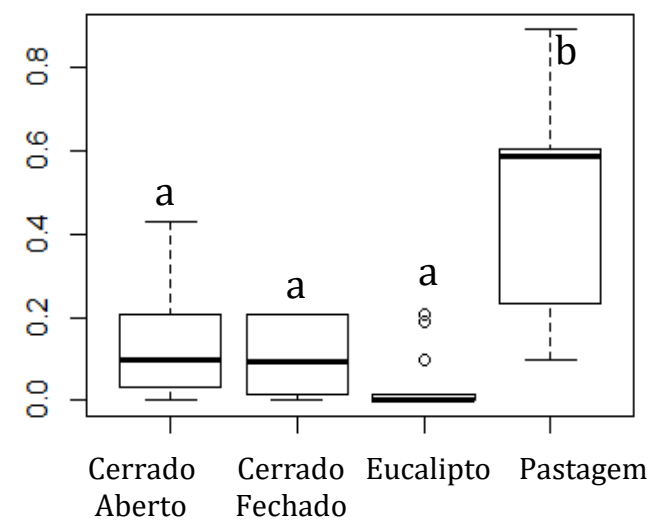

b) Riqueza funcional Multivariada

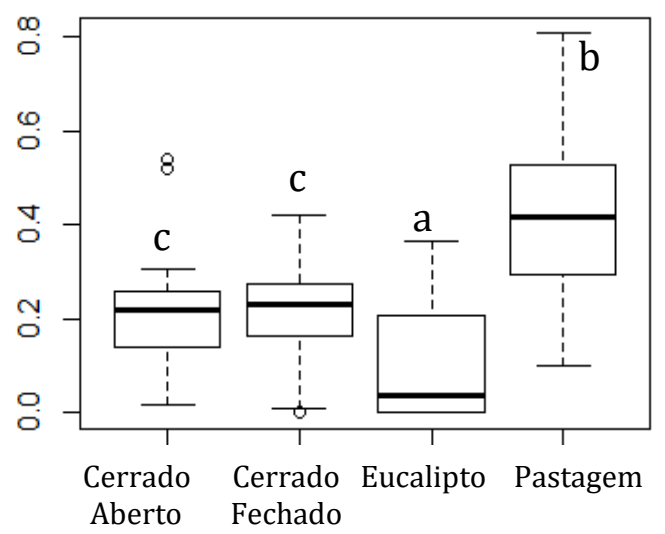

d) Riqueza funcional - Dieta

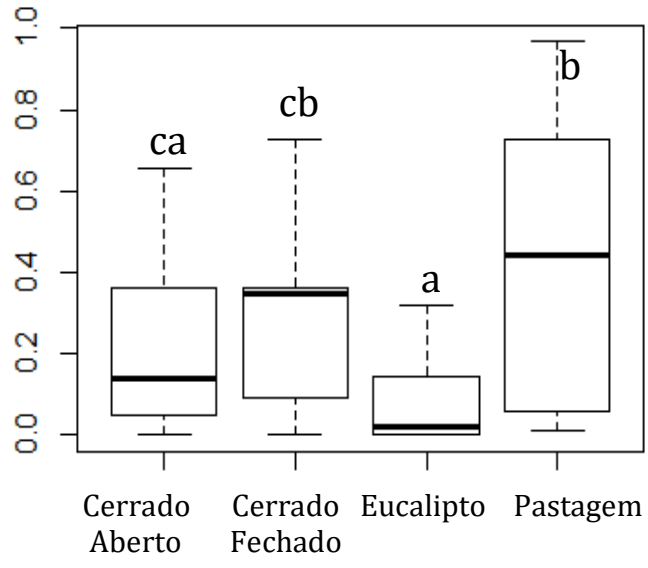

f) Riqueza funcional Local de nidificação

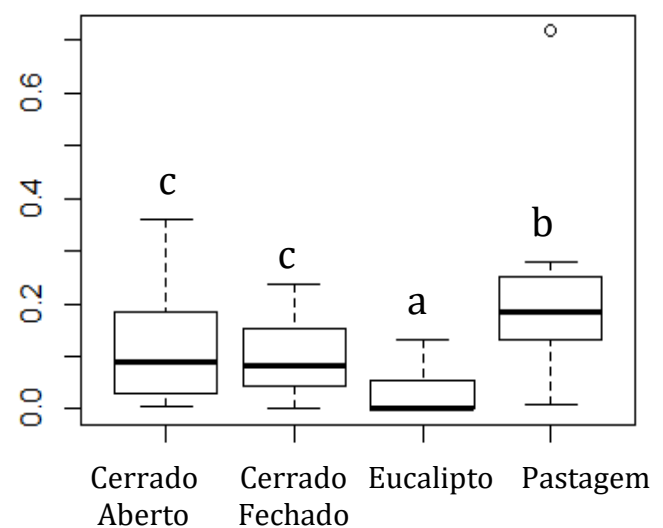

Figura 5: Comparação entre os ambientes com relação à riqueza biológica, riqueza funcional multivariada e riqueza funcional para: a) massa, b) dieta, c) estratégia de forrageio e d) local de nidificação. As letras nas barras indicam os ambientes que apresentaram diferença significativa para a $<0,05$ no Teste ANOVA e teste pós-hoc de Tukey. 


\section{Discussão}

Os resultados obtidos a partir da análise de agrupamento mostraram que o Eucalipto apresenta maior similaridade com o Cerrado fechado. Observamos também maior similaridade entre Cerrado aberto e pastagem, provavelmente porque esses ambientes apresentam estrutura da vegetação semelhante, onde Cerrado fechado e Eucalipto são ambientes florestais e Cerrado aberto e Pastagem são ambientes campestres. Nesse sentido, verificamos que não apenas a composição da vegetação, mas também a estrutura é importante para o estabelecimento das espécies de aves nos ambientes. Piratelli e Campos-Silva (2020) encontraram resultados semelhantes aos nossos, ao demonstrarem que a estrutura da vegetação em áreas naturais urbanas é um fator determinante para a riqueza e diversidade biológica e funcional das aves.

A comparação da composição de espécies de cada ambiente com o tipo de hábitat utilizado por elas revela que, de fato, o Cerrado aberto difere das outras comunidades, por abrigar mais espécies de aves diurnas exclusivas da vegetação campestre (Tabela 2), ou seja, de acordo com Motta-Júnior (2008) essas espécies ocorrem apenas em áreas abertas naturais de Cerrado, sendo extremamente sensíveis ao adensamento da vegetação. De modo semelhante, a comunidade de aves presentes nas áreas de cerrado fechado é composta por mais espécies associadas à vegetação nativa florestal, que preferem essas formações, mas podem também utilizar áreas campestres naturais. Já as Pastagens e as silviculturas de Eucalipto não apresentaram diferença significativa com relação à preferência de habitat pelas espécies, o que pode indicar a predominância de espécies generalistas para uso de habitat nesses ambientes modificados. Provavelmente isso ocorre, pois, as espécies especialistas de hábitat são mais sensíveis às modificações no ambiente e são mais rapidamente eliminadas das áreas alteradas, em um processo de extinção local.

Apesar das áreas alteradas não diferirem com relação à preferência de habitat pelas espécies de aves, podemos perceber no dendrograma de similaridade (Fig. 3), que as comunidades diferem em composição. Além disso, alguns dos pontos de observação realizados no Eucalipto (em vermelho) apresentaram-se misturados a outras fisionomias, indicando que o Eucalipto possui espécies que são também comuns nos outros ambientes. De fato, o Eucalipto foi o único ambiente que não apresentou nenhuma espécie exclusiva, 
uma vez que todas as espécies amostradas nos pontos de Eucaliptos também ocorreram em pelo menos um outro ambiente, isso indica que esse ambiente é composto por espécies generalistas.

O Eucalipto foi mais pobre do que os outros três ambientes em riqueza biológica, riqueza funcional multivariada e em riqueza de local de nidificação. Isso significa que, além desse ambiente possuir o menor número de espécies e espécies que não têm preferência por um tipo de habitat, a avifauna do Eucalipto também ocupa o menor espaço funcional e a menor variedade em locais de nidificação, quando comparado com os outros três ambientes. Isso acontece possivelmente por conta da simplificação da estrutura da vegetação, que resulta em escassez de lugares e de recursos para construção de ninhos. Além disso, o eucalipto apresentou menor riqueza em itens alimentares (dieta) do que o cerrado fechado e a pastagem. Esse resultado nos mostra que a perda de espécies não acarreta apenas em perda de biodiversidade, mas também em perda de funcionalidade do ecossistema, o que leva à diminuição da resiliência a perturbações. A menor variedade em itens de dieta pode indicar perda no potencial de serviços ecossistêmicos prestados pelas aves, tais como controle de pragas agrícolas, dispersão de sementes e polinização (Whelan, et al., 2015). Nossos dados estão em consonância com os resultados de Millan et al. (2015), que demonstraram que a conversão de áreas de Cerrado em plantações de eucaliptos resultou em perda das espécies mais sensíveis a alterações e das espécies seletivas de aves, já que, em seu estudo a comunidade que frequentava as áreas de silvicultura foi um subconjunto da comunidade presente na área de vegetação nativa próxima. São necessários estudos futuros que avaliem o uso que as aves fazem de silviculturas de Eucalipto com sobosque de regeneração nativa, para que possamos adotar estratégias que aliem a produção silvicultural com o menor impacto sobre a biodiversidade de aves.

Com relação à pastagem plantada com braquiárias (Urochloa spp.), nossos dados revelaram que esse ambiente apresentou maior riqueza funcional multivariada, maior riqueza de estratégia de forrageio e maior riqueza de local de nidificação do que os outros três ambientes. No entanto, é importante notar que a variância dessa comunidade com relação à massa, dieta e estratégia de forrageio foi muito alta, o que pode indicar que o valor elevado de riqueza funcional provavelmente foi encontrado devido à grande variabilidade dos pontos amostrais. Nesse sentido, a Pastagem incluiu pontos com valores muito baixos e outros com valores muito altos para esses traços (Figura 5). Essa 
grande variância pode ser explicada pela heterogeneidade das paisagens agrícolas visitadas, conforme sua proximidade a fragmentos de vegetação nativa e a corpos d'água, o que pode influenciar muito em relação às espécies que frequentam cada local. A maior riqueza em espécies da Pastagem em relação ao Eucalipto pode ser explicada devido à maior permeabilidade desse ambiente à avifauna quando comparado à permeabilidade das plantações de Eucalipto. Nesse mesmo sentido, Barros et al. (2019) verificaram que a provisão de serviços ecossistêmicos por aves na interface floresta-pasto foi maior do que na interface floresta-eucalipto. No entanto, é conhecido que muitas das espécies registradas nesta pesquisa e que foram exclusivas da Pastagem têm hábito arborícola e provavelmente não se estabelecem nesse ambiente isolado, mas o visitam e o atravessam usando as árvores esparsas como trampolins. São exemplos dessas espécies dependentes de ambientes arborizados e que foram registradas apenas nas pastagens: Tersina viridis, Myiozetetes similis, Colonia colonus, Amazona aestiva, Ictinia plúmbea, Herpetotheres cachinnans, Tangara palmarum, Forpus xanthopterygius e Tolmomyias sulphurescens. É importante considerar que as pastagens presentes nas paisagens agrícolas estudadas muitas vezes se situavam próximas às sedes das propriedades, comumente arborizadas com espécies frutíferas atrativas para as aves frugívoras. Essa pode ser uma explicação para o maior valor encontrado para riqueza em dieta nos ambientes de Pastagem em relação aos de Cerrado aberto. Devemos ressaltar que o fato dessas espécies terem sido amostradas nas pastagens não significa que elas necessariamente as utilizam como principal área de forrageio. Estudos futuros são necessários para melhor compreendermos se essas espécies de fato fazem uso das pastagens ou apenas a visitam enquanto atravessam a paisagem. Devido à ausência de Pastagens extensas e isoladas na região sudeste encontramos grande dificuldade em isolar esse ambiente durante a amostragem, sendo isso, portanto, uma limitação da presente pesquisa. Sugerimos que estudos futuros relacionem a distância de dispersão de cada espécie presente no pasto com o tamanho da área de Pastagem amostrada.

Boesing et al. (2021) demonstraram que tanto a quantidade de vegetação nativa quanto a distância aos remanescentes influenciam na obtenção de recursos alimentares pelas aves em matrizes dominadas por pastagem. Mesmo as aves que conseguem habitar essas pastagens, e que foram consideradas mais 'generalistas', são dependentes das matas para obter cerca de $60 \%$ de seu alimento. Nesse mesmo sentido, Barros et al (2019) encontraram que a cobertura florestal na paisagem foi o principal fator preditor da 
provisão do serviço ecossistêmico de controle de pragas. As aves generalistas foram as principais provisoras dos serviços de polinização e dispersão de sementes, sendo a densidade de casas rurais o principal fator preditor do potencial desses serviços.

Podemos considerar as fisionomias de Cerrado aberto e fechado em conjunto como um ambiente natural, já que essas áreas se apresentam formando um mosaico contínuo de vegetação nativa nas unidades de conservação. Nesse sentido, os ambientes de vegetação nativa de cerrado (cerrado fechado + cerrado aberto) juntos são mais ricos em espécies do que as áreas alteradas (Pastagem + Eucalipto) juntas. Assim, as áreas naturais somaram 90 espécies no total e 45 (37,8\%) espécies exclusivas.

Penteado e colaboradores (2016) também compararam as comunidades de aves em quatro tipos de ambientes no estado de São Paulo: vegetação nativa (Floresta Estacional Semidecidual), silvicultura de Eucalipto, pastagem e cana-de-açúcar. Seus resultados foram semelhantes aos nossos, onde as áreas de vegetação nativa foram mais ricas em espécies de aves do que os outros ambientes. Além disso, as áreas de monoculturas de Eucalipto e de cana-de-açúcar foram menos diversas que as Pastagens e as florestas nativas. Os autores também verificaram que os fragmentos de vegetação nativa apresentaram um número maior de espécies exclusivas e mais espécies especialistas do que os ambientes alterados. Por fim, espécies de aves nativas do Cerrado foram abundantes nas áreas de pastagens e muitas espécies estavam associadas ao gado. Nossos resultados corroboram os encontrados por Penteado et al (2016), pois também verificamos presença de aves nativas associada a ambientes arborizados nas áreas de Pastagem. Assim, é evidente a necessidade de preservação das áreas nativas de Cerrado, pois grande parte da diversidade de aves nativas que ocorrem nas pastagens é altamente dependente dos ambientes conservados de vegetação natural. Desse modo, reforçamos que paisagens agrícolas podem abrigar grande diversidade biológica se forem mantidas áreas de vegetação nativa em conformidade com a legislação brasileira, como Reserva Legal e Área de Preservação Permanente (Metzger et al., 2019).

Além da perda de habitats naturais, atualmente, as áreas de cerrado aberto no estado de São Paulo vêm sofrendo forte adensamento da vegetação (Durigan \& Ratter, 2016). Nossos dados demonstram, a partir do dendrograma de similaridade e da comparação entre preferência de habitat, que as comunidades de Cerrado aberto abrigam uma diversidade de avifauna específica e diferente daquela presente no Cerrado fechado. 
Nesse sentido, a perda dessas áreas resulta na perda de espécies exclusivas que não estão inserida nas áreas de cerrado fechado. Batalha e colaboradores (2010) simularam os efeitos para a avifauna da perda das fisionomias abertas de Cerrado e encontraram que haveria redução em $27 \%$ da diversidade funcional, o que resultaria na simplificação dos ecossistemas e prejuízo no funcionamento das comunidades.

Esta pesquisa demonstrou que a composição biológica da comunidade muda consideravelmente conforme a estrutura do ambiente, mesmo em áreas próximas umas das outras. Além disso, a silvicultura de Eucaliptos acarreta forte empobrecimento do número de espécies e da riqueza funcional da comunidade de aves, dada a simplificação que esse ambiente apresenta. Isso resulta na diminuição da capacidade de resiliência ecológica e das funções ecossistêmicas. Ressaltamos também que, apesar da comunidade da avifauna presente nas pastagens ser rica em espécies e em traços funcionais, grande parte das espécies desse ambiente não se estabelecem nesse ambiente isoladamente, pois são dependentes de áreas com vegetação nativa próximas. Reforçamos a importância das áreas nativas de vegetação de Cerrado como refúgios de espécies sensíveis e exclusivas dos ambientes naturais e, mais do que isso, mostramos que as fisionomias abertas e fechadas de Cerrado diferem com relação à composição específica da avifauna. Nesse sentido, é muito importante que esforços sejam direcionados à conservação das áreas de Cerrado com diferentes fitofisionomias, com foco de manter a diversidade estrutural, biológica e funcional que esse bioma abriga. 


\section{Referências}

Barros, F. M.; Peres, C. A.; Pizo, M. A. \& Ribeiro, M. C. (2019). Divergent flows of avian-mediated ecosystem services across forest-matrix interfaces in humanmodified landscapes. Landscape Ecology, 34, pp. 879-894. https://doi.org/10.1007/s10980-019-00812-Z

Batalha, M. A.; Cianciaruso, M. V. \& Motta-Junior, J.C. (2010). Consequences of Simulated Loss of Open Cerrado Areas to Bird Functional Diversity. Natureza \& Conservação, 8(1), pp.34-40.

Boesing, A. L.; Marques, T. S.; Martinelli, L. A. Nichols, E.; Siqueira, P. R.; Beier, C.; Camargo, P. B. \& Metzger, J. P. (2021). Conservation implications of a limited avian cross-habitat spillover in pasture lands. Biological Conservation, 253. https://doi.org/10.1016/j.biocon.2020.108898

Boesing, A. L.; Nichols, E. \& Metzger, J. P. (2018). Land use type, forest cover and forest edges modulate avian cross-habitat spillover. J Appl Ecol. 55, pp. 1252- 1264. https://doi.org/10.1111/1365-2664.13032

Campos, B. M.; Charters, J. D. \& Verdade, L. M. (2018). Diversity and distribution patterns of medium to large mammals in a silvicultural landscape in south-eastern Brazil. iForest 11, pp. 802-808. doi: 10.3832/ifor2721-011

Coutinho, L.M. (1978). O conceito de cerrado. Rev. Bras. Bot. 1(1), pp.17-23.

Coutinho L.M. (1990) Fire in the Ecology of the Brazilian Cerrado. In: Goldammer J.G. (Eds). Fire in the Tropical Biota. Ecological Studies (Analysis and Synthesis), vol 84. Springer, Berlin, Heidelberg. https://doi.org/10.1007/978-3-642-75395-4_6

Develey, P. F. 2004. Efeitos da fragmentação e do estado de conservação da floresta na diversidade de aves de Mata Atlântica. Tese de Doutorado. Instituto de Biociências, Universidade de São Paulo.

Develey, P.F., Cavana, D.D. \& Pivello, V.R. 2005. Aves. In Pivello, V.R. \& Varanda, E.M. (Orgs.). O cerrado Pé-de-Gigante: ecologia e conservação - Parque Estadual de Vassununga. Secretaria do Meio Ambiente, São Paulo, pp.121-134. 
Durigan, G. \& Ratter, J. A. (2016). The need for a consistence fire policy for Cerrado conservation. Journal of Applied Ecology, 53, pp.11-15

Endrigo, E. 2010. Aves - Estado de São Paulo. Ed. Aves e Fotos, São Paulo. 172p.

Fidelis, A. \& Pivello, V. R. (2011). Deve-se usar o fogo como instrumento de manejo no Cerrado e Campos Sulinos? Biodiversidade Brasileira, 2, pp.12-25.

Gwynne, J. A.; Ridgely, R. S.; Tudor, G. \& Argel, M. 2011. Aves do Brasil, Pantanal e Cerrado. Wildlife Conservation Society. Ed. Horizonte, Vinhedo, SP. pp. 322.

Hammer, O., Harper, D.A.T., Ryan, P.D. (2001). PAST: Paleontological statistics software package for education and data analysis. Palaeontologia Electronica 4(1)pp. 1-9.

Henriques, R. P. B. 2005. Influência da história, solo e fogo na distribuição e dinâmica das fitofisionomias no bioma Cerrado. In: Scarlot, A.; Sousa-Silva, J. C. \& Felfili, J. M. (Orgs). Cerrado: ecologia, diversidade e conservação. Ministério do Meio Ambiente. Brasília: Ministério do Meio Ambiente, 439p.

Johnson, M.D., Kellermann, J.L. \& Stercho, M. (2010). Pest reduction services by birds in shade and sun coffee in Jamaica. Anim. Conserv. 13: 140-147.

Kooskimies, P. (1989). Birds as a tool in environmental monitoring. Ann. Zool. Fennici 26: $153-166$.

Maas, B.; Karp, D. S.; Bumrungsri, S.; Darras, K.; Gonthier, D.; Huang, J. C. C.; Lindell, A. C.; Maine, J. J.; Mestre, L.; Michel, N. L.; Morrison, E. B.; Perfecto, I.; Philpott, S. M.; Şekercioğlu, C. H.; Silva, R. M.; Taylor, P. J.; Tscharntke, T.; Van Bael, S. A.; Whelan, C. J. \& Williams-Guillén, K. (2015). Bird and bat predation services in tropical forests and agroforestry landscapes. Biol. Rev. 91:1081-1101.

Machado, R. B.; Ramos-Neto, M. B.; Pereira, P. G. P.; Caldas, E. F.; Gonçalves, D. A.; Santos, N. S.; Tabor, K. \& Steininger, M. 2004. Estimativas de perda da área do Cerrado brasileiro. Conservação Internacional, Brasília, DF.

Mason, H. N. M.; Mouillot, D. \& Lee, D. G. Functional Richness, functional evenness and functional divergence: the primary components of functional diversity. Journal of Vegetation Science, 16: 533-540. 
Melo, A. C. G. \& Durigan, G. (Orgs.) (2009). Plano de Manejo Estação Ecológica de Santa Bárbara (Resumo Executivo). Instituto Florestal, Secretaria Estadual do Meio Ambiente, estado de São Paulo, 25p.

Metzger, J. P.; Bustamante, M. M.C.; Ferreira, J.; Fernandes, G. W.; Librán-Embid, F.; Pillar, V. D.; Prist, P. R.; Rodrigues, R. R.; Vieira, I. C. G.; Overbeck, G. E. (2019). Why Brazil needs its Legal Reserves. Perspectives in Ecology and Conservation, 17: 91 .

Millan, C. H.; Develey, P. F. \& Verdade, L. M. (2015). Stand-level management practices increase occupancy by birds in exotic Eucalyptus plantations. Forest Ecology and Management 336:174-182.

Mirada, H. S. \& Sato, M. N. 2005. Efeitos do fogo na vegetação lenhosa do Cerrado. In: Scarlot, A.; Sousa-Silva, J. C. \& Felfili, J. M. (Orgs). Cerrado: ecologia, diversidade e conservação. Ministério do Meio Ambiente. Brasília: MMA, 439p.

Monteiro, J. B. (Coord.). 2009. Plano de Manejo do Parque Estadual de Vassununga. Secretaria do Meio Ambiente, Instituto Florestal, Fundação Florestal, São Paulo, $328 \mathrm{p}$.

Morandini, R. 2013. Diversidade funcional das aves do Cerrado com simulações da perda de fisionomias campestres e de espécies ameaçadas: implicações para a conservação. Dissertação de Mestrado. Instituto de Biociências, Universidade de São Paulo. São Paulo, Brasil.

Motta-Junior, J.C.; Granzinolli, M.A.M. \& Develey, P.F. (2008). Aves da Estação Ecológica de Itirapina, estado de São Paulo, Brasil. Biota Neotropica 8(3): 207227. https://www.scielo.br/scielo.php?script=sci_arttext\&pid=S167606032008000300019

Myers, N.; Mittermeier, R. A.; Mittermeier, C. G.; Fonseca, G. A. B. \& Kent, J. (2000). Biodiversity hotspots for conservation priorities. Nature, 403: 853-858. 
Penteado, M., Yamashita, C., Marques, T. S., \& Verdade, L. M. 2016. Bird diversity in relation to land use in agricultural landscapes of southeastern Brazil. In C. In Gheler Costa, M. C. Lyra-Jorge, \& L. M. Verdade (Eds.). Biodiversity in agricultural landscapes of Southeastern Brazil. Berlin: De Gruyter. 243-268p.

Philpott, S. M., Soong, O., Lowenstein, J. H., Pulido, A. L., Lopez, D. T., Flynn, D. F. B. \& Declerck, F. (2009). Functional richness and ecosystem services: Bird predation on arthropods in tropical agroecosystems. Ecol. Appl. 19: 1858-1867.

Piratelli, L. A. \& Campos-Silva, A. J. (2020). Vegetation structure drives taxonomic diversity and functional traits of birds in urban private native forest fragments. Urban Ecosystems, 24: 375-390. https://doi.org/10.1007/s11252-020-01045-8

Pivello, V. R. (2011). The Use of fire in the cerrado and Amazonian rainforests of Brazil. Fire Ecology, 7(1): 24-39.

R Core Team (2017). R: A language and environment for statistical computing. R Foundation for Statistical Computing, Vienna, Austria. URL https://www.Rproject.org/

Roché, J.; Godinho, C.; Rabaça, J. E.; Frochot, B.; Faivre, B.; Mendes, A. \& Dias, P. C. (2010). Birds as bio-indicators and as tools to evaluate restoration measures. 7th European Conference on Ecological Restoration, Avignon, France. July 2010.

Simon, M. F. \& Penningtont, T. (2012). Evidence for adaptation to fire regimes in the tropical savannas of the brazilian cerrado. Int. J. Plant Sci. 173(6): 711-723.

Telles, M. \& Dias, MM. (2010). Comunidades de aves em dois fragmentos de Cerrado em Itirapina, Brasil. Braz. J. Biol., São Carlos, 70(3): 537-550.

Tilman, D. (2001). Functional Diversity. Encyclopedia of Biodiversity, 3: 109-121.

Vielliard, J. M. E; Almeida, M. E; Anjos, L \& Silva, W. R. (2010). Levantamento quantitativo por pontos de escuta e Índice Pontual de Abundância (IPA). In: Matter, S.; Straube, F. C.; Piacentini, V. Q.; Accordi, I. A. \& Cândido ; J. F. . 2010. Ornitologia e Conservação: Ciência Aplicada, Técnicas de Pesquisa e Levantamento. Rio de Janeiro. Tecnical Books Editora, 518 p. 
Villéger, S.; Mason, N.W.H. \& Mouillot, D. (2008). New multidimensional functional diversity indices for a multifaceted framework in functional ecology. Ecology, 89(8): 2290-2301.

Whelan, C. J.; Sekercioglu, C. H. \& Wenny, D. (2015). Why birds matter: from economic ornithology to ecosystem services. J. Ornithol., 156(1): 227-238.

Wiki Aves (http://www.wikiaves.com.br/) Acesso: 21 de fevereiro de 2021.

Willis, E.O. (1995). Algumas aves de hábitats especiais da região de Itirapina (São Paulo).

Atual. Ornit, 68: 1-7.

Willis, E. O. (2004). Birds of a habitat spectrum in the Itirapina Savanna, São Paulo, Brazil (1982-2003). Braz. J. Biol. São Carlos, 64(4): 901-910.

Xeno-canto: Compartilhando sons de aves do mundo todo. (http://www.xeno-canto.org) Acesso: 16 de outubro de 2019.

Zanchetta, D.; Delgado, J. M.; Silva, C. E. F.; Reis, C. M.; Silva, D. A.; Luca, E. F.; Fernandes, F de S. Dutra-Lutgens, H.; Tanus, J. L. S.; Pinheiro, L de S.; Martins, M. R. C \& Sawaya, R. São Paulo. (2006). Plano de Manejo Integrado Estações Ecológica e Experimental de Itirapina - SP. - $1^{\text {a }}$ Revisão. Instituto Florestal. São Paulo, 247p. Edição 2006. 


\section{CONCLUSÕES GERAIS}

Os trabalhos apresentados nessa tese buscaram ampliar o conhecimento acerca da diversidade de aves no Cerrado. Para isso, demonstramos o padrão de distribuição da avifauna em nível nacional a partir da construção de uma rede biogeográfica e explicamos como a diversidade associada às diferentes fitofisionomias no estado de São Paulo difere em termos de composição, riqueza biológica e funcional.

No Capítulo 1 foi demonstrado que:

- O padrão biogeográfico de distribuição das aves é formado por três módulos espacialmente distintos: Noroeste, Centro-sul e Centro-norte.

- A divisão tradicional do Cerrado brasileiro entre core e não-core não explica os padrões de distribuição da diversidade de avifauna.

- As áreas marginais de Cerrado são tão ricas e diversas quanto as áreas nucleares.

Nós demonstramos que as regiões marginais, como aquelas de enclaves amazônicos e da região sudeste do país, também guardam uma diversidade de aves significativa e única. A partir dos padrões encontrados, discutimos quais fatores poderiam estar influenciando na formação dos módulos. Nesse sentido, nossa pesquisa reforça que as áreas marginais de Cerrado são tão importantes quanto as áreas de cerrado core (ou nucleares) em termos de composição da diversidade de aves, o que ressalta a importância de estudar e conservar não apenas as áreas nucleares, mas também as áreas remanescentes de cerrado nas regiões Amazônicas e do Sudeste brasileiro.

No capítulo 2 verificamos que:

- As áreas naturais de Cerrado abrigam uma diversidade de aves que não está presente nas áreas alteradas de pastagem e silvicultura.

- Quando comparamos os dois principais usos do solo pela agricultura em áreas de Cerrado no estado de São Paulo (pastagem e silvicultura de eucalipto), percebemos que as pastagens são menos hostis às espécies de aves nativas do que os eucaliptos, que não são muito utilizados pelas aves nativas.

Os estudos desenvolvidos aqui contribuem com o conhecimento acerca dos efeitos da perda de áreas naturais abertas sobre a comunidade de aves e sua diversidade funcional. A partir da presente pesquisa pudemos entender melhor como as transformações dos 
ambientes naturais de cerrado afetam as comunidades de aves, bem como quais as perdas na diversidade funcional com essas transformações.

Além disso, nossos resultados dão subsídios para políticas de conservação e para planos de mitigação da perda de diversidade funcional de aves nas áreas remanescentes de Cerrado, bem como contribuem com o manejo de Unidades de Conservação em ambientes de Cerrado. Nossos resultados podem ser úteis para o planejamento e definição de novas áreas de proteção, uma vez que ressaltamos a importância das áreas que englobem tanto fitofisionomias fechadas, como abertas, já que as comunidades de aves presentes em cada uma delas é diferente em composição de espécies, mas igualmente rica. 


\section{SUPPLEMENTARY MATERIAL CAPÍTULO 1}

Table S1: Surveys on Cerrado birds used in the present study, carried out in different locations in Brazil.

\begin{tabular}{|c|c|c|c|}
\hline Study area (State) & Publication & Year & 焉 \\
\hline $\begin{array}{l}\text { Chapada dos } \\
\text { Guimarães (MG) }\end{array}$ & $\begin{array}{l}\text { L. E. Lopes; J. B. Pinho; B. Bernardon; F. F. Oliveira; G. } \\
\text { Bernardon; M. F. Vasconcelos; M. Maldonado-Coelho; P. F. A. } \\
\text { Nobrega, \& T. Rubio. Aves da Chapada dos Guimarães, MG, } \\
\text { Brasil: uma síntese histórica do conhecimento. Papéis Avulsos } \\
\text { de Zoologia, 49(2): 9-47. }\end{array}$ & 2009 & Yes \\
\hline $\begin{array}{l}\text { Rio das Mortes } \\
\text { (MT) }\end{array}$ & $\begin{array}{l}\text { H. Sick. Aspectos fitofisionomicos da paisagem do médio Rio } \\
\text { das Mortes, MT, e a avifauna da região. Arquivos do Museu } \\
\text { Nacional, 42: 541-576. }\end{array}$ & 1955 & No \\
\hline $\begin{array}{l}\text { Serra do Lajeado } \\
\text { (TO) }\end{array}$ & $\begin{array}{l}\text { M. A. Bagno. \& T. L. S. Abreu. Avifauna da região da Serra do } \\
\text { Lajeado. Humanitas, 3: 51-70. }\end{array}$ & 2001 & No \\
\hline $\begin{array}{l}\text { Parque Nacional } \\
\text { das Emas } \\
(\mathrm{GO} / \mathrm{MS} / \mathrm{MT})\end{array}$ & $\begin{array}{l}\text { A. Hass. Plano de Manejo do PNE/GO-MS-MT. Relatório de } \\
\text { avifauna. não publicado. }\end{array}$ & 2005 & Yes \\
\hline $\begin{array}{l}\text { Estação Ecológica } \\
\text { de Águas } \\
\text { Emendadas (DF) }\end{array}$ & $\begin{array}{l}\text { M. A. Bagno. As aves da Estação Ecológica de Águas } \\
\text { Emendadas. Vertebrados da ESECAE. SEMATEC, 92p. }\end{array}$ & 1998 & Yes \\
\hline $\begin{array}{l}\text { Estação Ecológica } \\
\text { de Âguas } \\
\text { Emendadas (DF) }\end{array}$ & $\begin{array}{l}\text { L. Lopes, L. Leite; J. B. Pinho \& R. Gomes. New birds records } \\
\text { to the Estação Ecológica de Águas Emendadas, Planaltina, DF. } \\
\text { Ararajuba, 13(1): 107-108. }\end{array}$ & 2005 & Yes \\
\hline $\begin{array}{l}\text { Estação Ecológica } \\
\text { de Âguas } \\
\text { Emendadas (DF) }\end{array}$ & $\begin{array}{l}\text { M. A. Bagno \& T. L. S. Abreu. Águas Emendadas. SEDUMA, } \\
\text { cap.7.4: 233-241. }\end{array}$ & & Yes \\
\hline $\begin{array}{l}\text { Reserva Ecológica } \\
\text { do IBGE (DF) }\end{array}$ & $\begin{array}{l}\text { D. T. Tubelis. Reserva ecológica do IBGE. Série Biodiversidade } \\
\text { Terrestre. IBGE, 1: 147-158. }\end{array}$ & 2011 & Yes \\
\hline $\begin{array}{l}\text { Parque Nacional de } \\
\text { Brasília (DF) }\end{array}$ & $\begin{array}{l}\text { P. T. Z. Antas. Aves do Parque Nacional de Brasília. Coleção } \\
\text { Meio Ambiente. Série Fauna Brasileira. IBAMA, 53p. }\end{array}$ & 1995 & Yes \\
\hline $\begin{array}{l}\text { Parque Nacional de } \\
\text { Brasília (DF) }\end{array}$ & $\begin{array}{l}\text { V. Braz. Ecologia e Conservação de aves campestres do bioma } \\
\text { cerrado. Tese Doutorado UnB, } 187 \mathrm{p} \text {. }\end{array}$ & 2008 & Yes \\
\hline $\begin{array}{l}\text { Parque Nacional de } \\
\text { Brasília (DF) }\end{array}$ & $\begin{array}{l}\text { A. C. Oliveira; M. F Keneage; M. F. Amaral \& F. L. Favaro. } \\
\text { Guia para observação de aves do Parque Nacional de Brasília } \\
\text { ICMBio, 300p. }\end{array}$ & 2011 & Yes \\
\hline $\begin{array}{l}\text { Fazenda Água } \\
\text { Limpa (DF) }\end{array}$ & $\begin{array}{l}\text { V. Braz \& R. B. Cavalcanti. A representatividade de áreas } \\
\text { protegidas do DF na conservação da avifauna do Cerrado. } \\
\text { Ararajuba, 9(1): 61-69. }\end{array}$ & 2001 & Yes \\
\hline
\end{tabular}




\begin{tabular}{|c|c|c|c|}
\hline $\begin{array}{l}\text { Parque Nacional da } \\
\text { Serra da Canastra } \\
\text { (MG) }\end{array}$ & $\begin{array}{l}\text { L. F. Silveira. The birds of Serra da Canastra National Park and } \\
\text { adjacent areas. Cotinga, 10: 55-63. }\end{array}$ & 1998 & Yes \\
\hline $\begin{array}{l}\text { Parque Nacional da } \\
\text { Serra do Cipó (MG) }\end{array}$ & $\begin{array}{l}\text { M. Rodrigues; L. A Carrara; L. P. Faria \& H. B. Gomes. Aves } \\
\text { do Parque Nacional da Serra do Cipó: o Vale do Rio Cipó, MG, } \\
\text { Brasil. Revista Brasileira de Zoologia, 22(2): 326-338. }\end{array}$ & 2005 & Yes \\
\hline $\begin{array}{l}\text { Estação Ecológica } \\
\text { de Itirapina (SP) }\end{array}$ & $\begin{array}{l}\text { J. C. Motta Junior, M. A. M. Grazinolli, P. F. Develey. Aves da } \\
\text { estação ecológica de Itirapina, estado de São Paulo, Brasil. Biota } \\
\text { Neotropica, 8(3): 207-227. }\end{array}$ & 2008 & Yes \\
\hline Itirapina (SP) & $\begin{array}{l}\text { M. Telles \& M. M. Dias. Bird communities in two fragments of } \\
\text { Cerrado in Itirapina, Brazil. Brazilian Journal of Biology, } 70(3) \text { : } \\
537-550 .\end{array}$ & 2010 & Yes \\
\hline Itirapina (SP) & E. O. Willis. Atualidades Ornitológicas, 68(7). & 1995 & Yes \\
\hline Itirapina (SP) & $\begin{array}{l}\text { E. O. Willis. Birds of a habitat spectrum in the Itirapina savanna, } \\
\text { SP, Brasil (1982-2003). Biology, 64(4): 901-910. }\end{array}$ & 2004 & Yes \\
\hline Cantão (TO) & $\begin{array}{l}\text { R. T. Pinheiro \& T. Dornas. Distribuição e conservação das aves } \\
\text { na região do Cantão, TO: ecotono Amazonia/Cerrado. Biota } \\
\text { Neotropica, 9(1): 188-205. }\end{array}$ & 2009 & Yes \\
\hline Jalapão (TO) & $\begin{array}{l}\text { J. F. Pacheco \& F. Olmos. As aves do Tocantins, Brasil - 2: } \\
\text { Jalapão. Revista Brasileira de Ornitologia, 18(1): 1-18. }\end{array}$ & 2010 & No \\
\hline $\begin{array}{l}\text { Planalto da } \\
\text { Bodoquena (MS) }\end{array}$ & $\begin{array}{l}\text { M. A. C. Pivatto; D. G. Manço; F. C. Straube; A. Rben-Filho \& } \\
\text { M. Milano. Aves do Planalto da Bodoquena, estado do Mato } \\
\text { Grosso do Sul (Brasil). Atualidades Ornitológicas, 129: 1-26. }\end{array}$ & 2006 & No \\
\hline Pedro Afonso (TO) & $\begin{array}{l}\text { L. E. Lopes \& V. S. Braz. Aves da região de Pedro Afonso, TO, } \\
\text { Brasil. Revista Brasileira de Ornitologia, 15(4): 530-537. }\end{array}$ & 2007 & No \\
\hline $\begin{array}{l}\text { Cerrado-Caatinga } \\
\text { transition area (PI) }\end{array}$ & $\begin{array}{l}\text { M. P. D. Santos. Bird community distribution in a Cerrado- } \\
\text { Caatinga transition area, PI, Brazil. Revista Brasileira de } \\
\text { Ornitologia, 16(4): 323-338. }\end{array}$ & 2008 & No \\
\hline $\begin{array}{l}\text { Southern Region in } \\
\text { Tocantins (TO) }\end{array}$ & $\begin{array}{l}\text { J. F. Pacheco \& F. Olmos. As aves do Tocantins, Brasil - 1: } \\
\text { Região Sudeste. Revista Brasileira de Ornitologia, 14(2): 85- } \\
100 .\end{array}$ & 2006 & No \\
\hline $\begin{array}{l}\text { Fazenda Brejão } \\
\text { (MG) }\end{array}$ & $\begin{array}{l}\text { L. C. P. Faria; L. A Carrara; F. Q Amaral; M. F. Vasconcelos; } \\
\text { M. G. Diniz; C.D. Encarnação; D Hoffmann; H. B. Gomes; L. E. } \\
\text { Lopes \& M. Rodrigues. The birds of Fazenda Brejão: a } \\
\text { conservation priority area of Cerrado in northwestern Minas } \\
\text { Gerais, Brazil. Biota Neotropica, } 9(3): 223-240 .\end{array}$ & 2009 & No \\
\hline $\begin{array}{l}\text { Estação Ecológica } \\
\text { Serra das Araras } \\
(\mathrm{MT})\end{array}$ & $\begin{array}{l}\text { J. M. C. Silva \& Y. Oniki. Lista preliminar da avifauna da } \\
\text { Estação Ecológica Serra das Araras, MT, Brasil. Boletim do } \\
\text { Museu Paranaense Emilio Goeldi, série Zoológica, 4(2): 123- } \\
143 .\end{array}$ & 1988 & Yes \\
\hline
\end{tabular}




\begin{tabular}{|c|c|c|c|}
\hline $\begin{array}{l}\text { Reserva Ecológica } \\
\text { Panga (MG) }\end{array}$ & $\begin{array}{l}\text { O. Marçal-Junior; A. G. Franchin; E. F. Altef; E. L. Silva-Junior } \\
\text { \& C. Melo. Levantamento da avifauna na Reserva Ecológica } \\
\text { Panga (Uberlandia, MG, Brasil). Biosci. J., 25(6): 149-164. }\end{array}$ & 2009 & Yes \\
\hline $\begin{array}{l}\text { Estação Ecológica } \\
\text { Serra Geral (TO) }\end{array}$ & $\begin{array}{l}\text { M. A. Rego, L. F. Silveira; V. Q. Piacentini; F. Schunck; E. } \\
\text { Machado; R. T. Pinheiro \& E. Reis. As aves da Estação } \\
\text { Ecológica Serra Geral do TO, Centro do Brasil. Biota } \\
\text { Neotropica, 11(1): 283-297. }\end{array}$ & 2011 & Yes \\
\hline $\begin{array}{l}\text { Complexo Aporé- } \\
\text { Sucuriú (MS) }\end{array}$ & $\begin{array}{l}\text { M. B. Silva; C. F. Zucca; C. R. Souza; S. Mamede; P. I. Pina \& } \\
\text { I. R. Oliveira. Inventário da avifauna no Complexo Aporé- } \\
\text { Sucuriú. In: Biodiversidade do Complexo Aporé-Sucuriú: } \\
\text { subsídios à conservação e manejo do bioma Cerrado - Área } \\
\text { prioritária } 316 \text { Jauru. Editora UFMS, 308p. }\end{array}$ & 2006 & No \\
\hline Rio Manso (MT) & $\begin{array}{l}\text { L. A. S. Vasconcellos \& D. M. M. Oliveira. Avifauna. In: Alho, } \\
\text { C.J.R. (Ed.), Fauna silvestre da região do Rio Manso, MT. } \\
\text { IBAMA-Eletronorte, 191-216. }\end{array}$ & 2000 & No \\
\hline Paracatu (MT) & C. E. Benfica. Lista de aves de Paracatu. Unpublished data. & & No \\
\hline $\begin{array}{l}\text { Parque Estadual do } \\
\text { Juqueri (SP) }\end{array}$ & $\begin{array}{l}\text { L. F. Figueiredo, C. O. A. Gussoni \& R. P. Campos. } \\
\text { Levantamento da avifauna do Parque Estadual do Juquery, } \\
\text { Franco da Rocha, SP: uma avaliação autocrítica das técnicas de } \\
\text { campo para inventários ornitológicos. Boletim CEO, 14:36-43. }\end{array}$ & 2000 & Yes \\
\hline $\begin{array}{l}\text { Campus da USP de } \\
\text { Pirassununga (SP) }\end{array}$ & $\begin{array}{l}\text { C. O. A. Gussoni. Avifauna do campus da USP, Município de } \\
\text { Pirassununga, Estado de SP. Boletim CEO, 15: 2-15. }\end{array}$ & 2003 & No \\
\hline $\begin{array}{l}\text { Parque estadual de } \\
\text { Vassununga, Gleba } \\
\text { Pé-de-Gigante (SP) }\end{array}$ & $\begin{array}{l}\text { P. F. Develey, Cavana, D. D. \& V. R. Pivello. Aves. In: Pivello, } \\
\text { V.R. \& Varanda, E.M. (orgs.). O Cerrado Pé-de-Gigante (Parque } \\
\text { Estadual de Vassununga, SP) - ecologia e conservação. SMA- } \\
\text { SP, 312p. }\end{array}$ & 2005 & Yes \\
\hline $\begin{array}{l}\text { Estação Ecológica } \\
\text { de Jataí e Estação } \\
\text { Experimental de } \\
\text { Luiz Antônio (SP) }\end{array}$ & $\begin{array}{l}\text { M. M. Dias. Avifauna das Estações Ecológicas de Jataí e } \\
\text { Experimental de Luiz Antônio, São Paulo, Brasil. In Santos J. E. } \\
\text { e Pires, J. S. R. (Eds.). Estação Ecológica de Jataí. Editora Rima, } \\
\text { 1: 285-301. }\end{array}$ & 2000 & Yes \\
\hline $\begin{array}{l}\text { Chapada do Araripe } \\
\text { (CE) }\end{array}$ & $\begin{array}{l}\text { J. L. A. S. Nascimento, I. L. Nascimento, \& S. M. Azevedo- } \\
\text { Junior. Aves da Chapada do Araripe (Brasil): biologia e } \\
\text { conservação. Ararajuba, 115-125. }\end{array}$ & 2000 & No \\
\hline $\begin{array}{l}\text { Campus da } \\
\text { UFSCar, São } \\
\text { Carlos (SP) }\end{array}$ & $\begin{array}{l}\text { J. C. Motta Junior \& L. A. Vasconcellos. Levantamento das aves } \\
\text { do campus da UFSCar, SP, Brasil. Anais do VII Seminário } \\
\text { Regional de Ecologia, 7: 159-171. }\end{array}$ & 1996 & No \\
\hline $\begin{array}{l}\text { Alta Floresta } \\
\text { Region (MT) }\end{array}$ & $\begin{array}{l}\text { K. J. Zimmer; T. A. Parker III; M. L. Isler \& P. R. Isler. Survey } \\
\text { of a Southern Amazonian Avifauna: The Alta Floresta Region, } \\
\text { MT, Brazil. Ornithological Monographs, 48: 887-918. }\end{array}$ & 1997 & No \\
\hline $\begin{array}{l}\text { Área de Proteção } \\
\text { Ambiental do Rio } \\
\text { Curiaú (AP) }\end{array}$ & $\begin{array}{l}\text { K. M. O. Aguiar \& R. H. Naiff. Composição da avifauna da } \\
\text { Área de Proteção Ambiental do Rio Curiaú, Macapá, AP, Brasil. } \\
\text { Ornithologia, 4(1): 36-48. }\end{array}$ & 2010 & Yes \\
\hline
\end{tabular}




\begin{tabular}{|c|c|c|c|}
\hline $\begin{array}{l}\text { Vila Bela Region, } \\
\text { Santíssima } \\
\text { Trindade (MT) }\end{array}$ & $\begin{array}{l}\text { L. F. Silveira \& F. M. D'horta. A avifauna da região de Vila Bela } \\
\text { da Santíssima Trindade, MT. Papéis Avulsos de Zoologia, } \\
\text { 42(10): 265-286. }\end{array}$ & 2002 & No \\
\hline $\begin{array}{l}\text { Parque estadual do } \\
\text { Cerrado (PR) }\end{array}$ & $\begin{array}{l}\text { F. C. Straube, A. Urben-Filho, C. Gatto. A avifauna do Parque } \\
\text { Estadual do Cerrado (Jaguariaíva, PR) e a conservação do } \\
\text { Cerrado em seu limite meridional de ocorrência. Atualidades } \\
\text { Ornitológicas, 127: 29-49. }\end{array}$ & 2005 & Yes \\
\hline $\begin{array}{l}\text { Savanas do Amapá } \\
\text { (AP) }\end{array}$ & $\begin{array}{l}\text { J. M. C. Silva; D. C. Oren; J. C. Roma \& L. M. P. Henriques. } \\
\text { Composition and distribution patterns of the avifauna of an } \\
\text { Amazonian upland savanna, AP, Brazil. Ornithological } \\
\text { Monographs, 48: 743-762. }\end{array}$ & 1997 & No \\
\hline $\begin{array}{l}\text { Savanas do Amapá } \\
\text { (AP) }\end{array}$ & $\begin{array}{l}\text { R. L. Boos. Variações espaciais e temporais em comunidades de } \\
\text { aves de uma savana amazonica no Estado do AP. Dissertação de } \\
\text { mestrado UNIFAP, 153p. }\end{array}$ & 2009 & No \\
\hline $\begin{array}{l}\text { Enclave in Southern } \\
\text { Brazilian Amazonia } \\
\text { (AM) }\end{array}$ & $\begin{array}{l}\text { A. Aleixo \& F. Poletto. Birds of an open vegetation enclave in } \\
\text { Southern Brazilian Amazonia. The Wilson Journal of } \\
\text { Ornithology, 119(4): 610-630. }\end{array}$ & 2007 & No \\
\hline $\begin{array}{l}\text { Serra do Cachimbo } \\
\text { (PA) }\end{array}$ & $\begin{array}{l}\text { M. P. D. Santos, L. F. Silveira, \& J. M. C. Silva. Birds of Serra } \\
\text { do Cachimbo, Pará State, Brazil. Revista Brasileira de } \\
\text { Ornitologia, 19(2): 244-259. }\end{array}$ & 2011 & No \\
\hline Balsas region (MA) & $\begin{array}{l}\text { A. Hass, W. S. Paula, \& L. Barreto. Caracterização da avifauna } \\
\text { da região de Balsas. In: Barreto, L. Cerrado Norte do Brasil. } \\
\text { USEB, 378p. }\end{array}$ & 2007 & No \\
\hline $\begin{array}{l}\text { Alter de Chão } \\
\text { (AM) }\end{array}$ & $\begin{array}{l}\text { T. M. Sanaiotti \& R. Cintra. Breeding and Migrating Birds in an } \\
\text { Amazonian Savanna. Studies of Neotropical Fauna and } \\
\text { Environment, 1: 23-32. }\end{array}$ & 2001 & No \\
\hline $\begin{array}{l}\text { Roraima Savannas } \\
\text { (RR) }\end{array}$ & $\begin{array}{l}\text { M. P. D. Santos \& J. M. C. Silva. As aves das savanas de } \\
\text { Roraima. Revista Brasileira de Ornitologia, 15(2): 189-207. }\end{array}$ & 2007 & No \\
\hline $\begin{array}{l}\text { Estação Ecológica } \\
\text { de Santa Bárbara } \\
\text { (SP) }\end{array}$ & $\begin{array}{l}\text { A. S. Lucindo; A. Z.Antunes; M. M. Kanashiro \& M. M. Dias. } \\
\text { Birds at Santa Barbara Ecological Station, one of the last } \\
\text { Cerrado remnants in the state of São Paulo, Brasil. Biota } \\
\text { Noetropica 15(4): e0155 }\end{array}$ & 2015 & Yes \\
\hline Rio do Fogo (RN) & $\begin{array}{l}\text { M. Pichorim; M. Silva; B. R. A. França; T. M. Oliveira-Júnior \& } \\
\text { M. C. Rodrigues. A Cerrado Bird Community in the } \\
\text { northernmost portion of the northeastern Brasil - } \\
\text { recommendations for conservation. Revista Brasileira de } \\
\text { Ornitologia 22(4) 347-362. }\end{array}$ & 2014 & No \\
\hline
\end{tabular}


Table S2. Shapiro-Wilk normality test for the metrics $c, z$ and degree, showing that only $z$ is not normally distributed. The level of significance was 0.0166 after Bonferroni correction.

\begin{tabular}{ccc}
\hline Variable & W & p-value \\
\hline Degree & 0.9828 & 0.7689 \\
$\mathbf{c}$ & 0.95333 & 0.08504 \\
$\mathbf{z}$ & 0.82399 & $1.499 \mathrm{e}-05$ \\
\hline
\end{tabular}


Table S3. Matrix with 42 sites and 971 bird species that composed the first network.
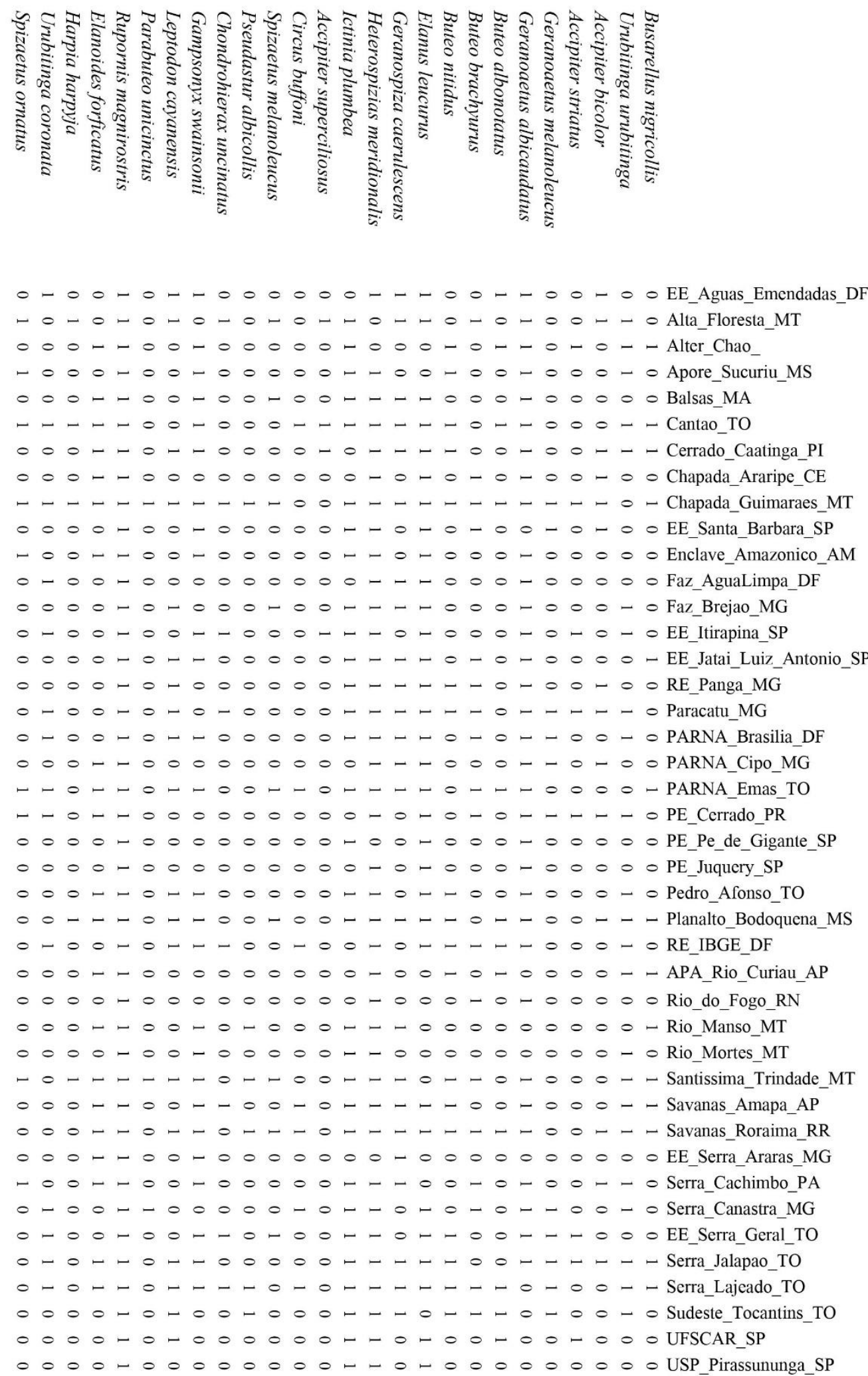

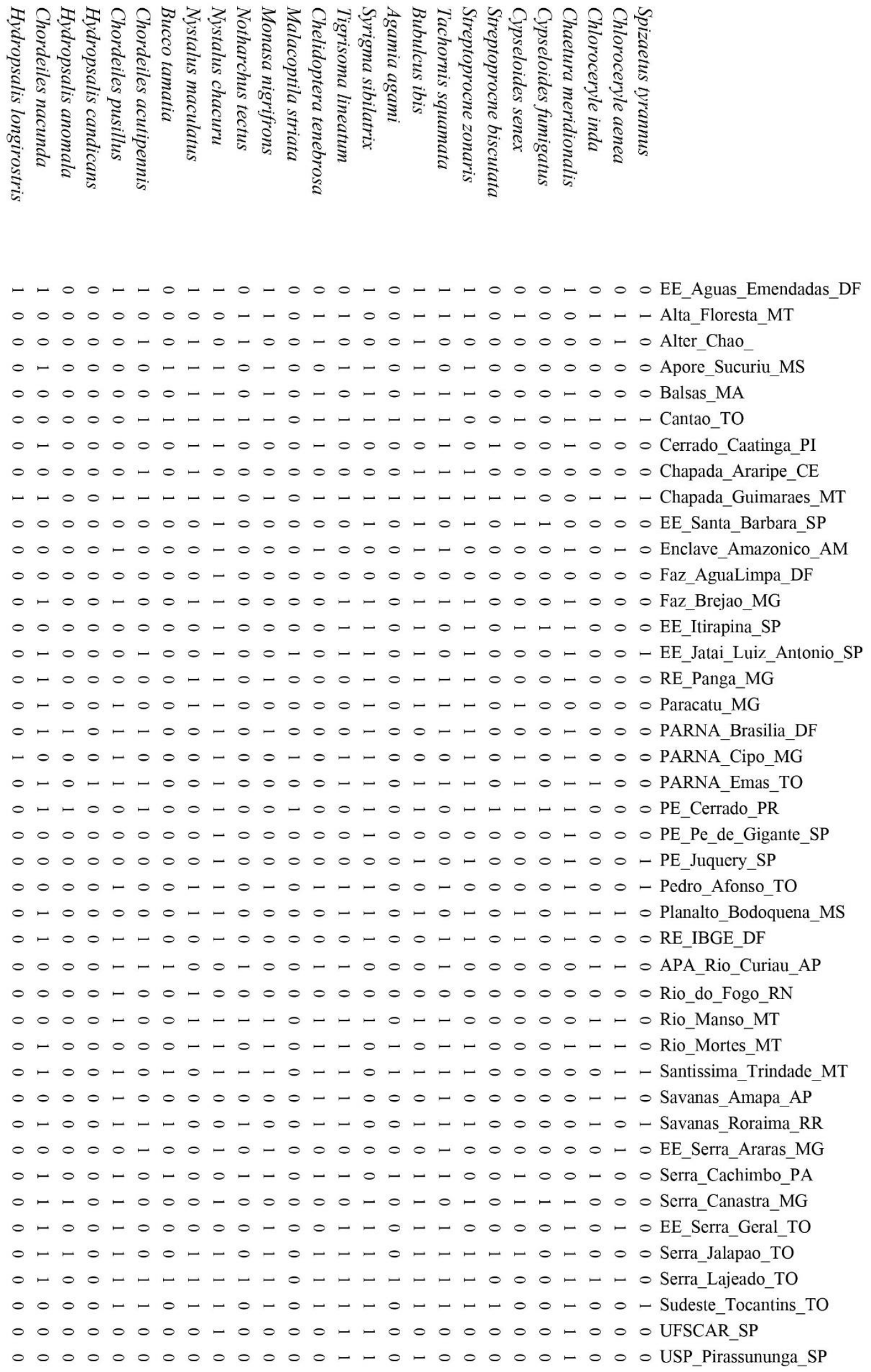

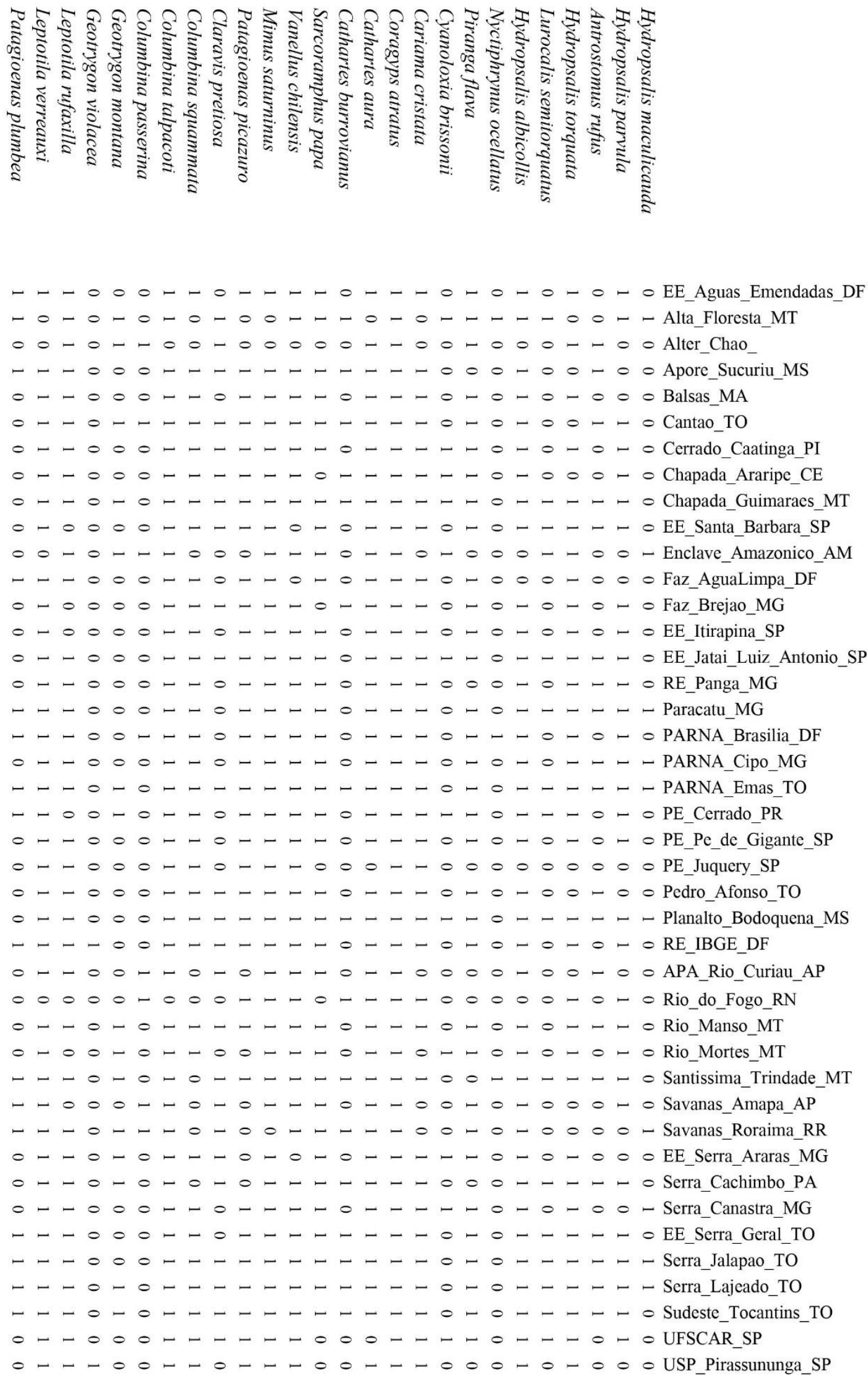

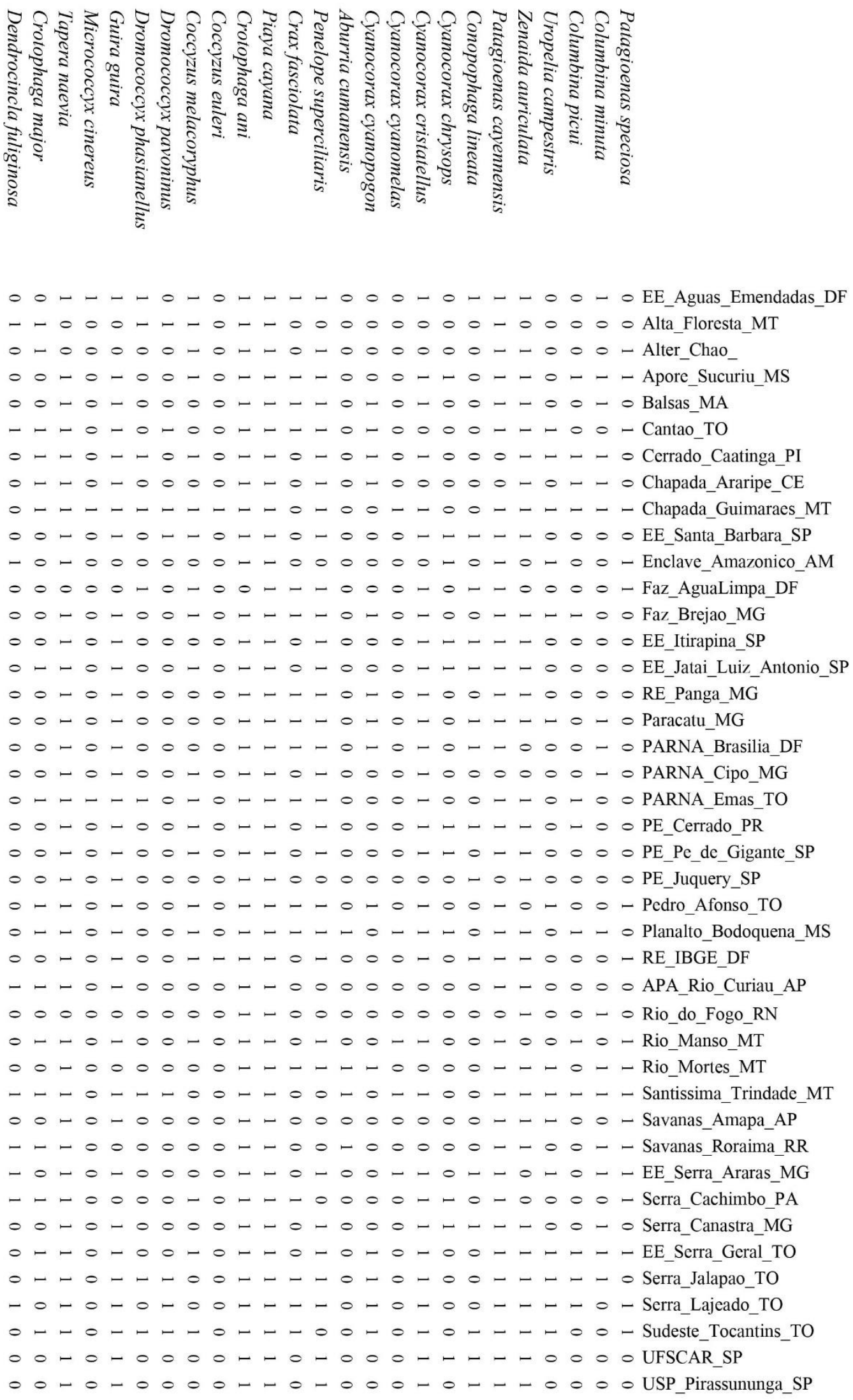

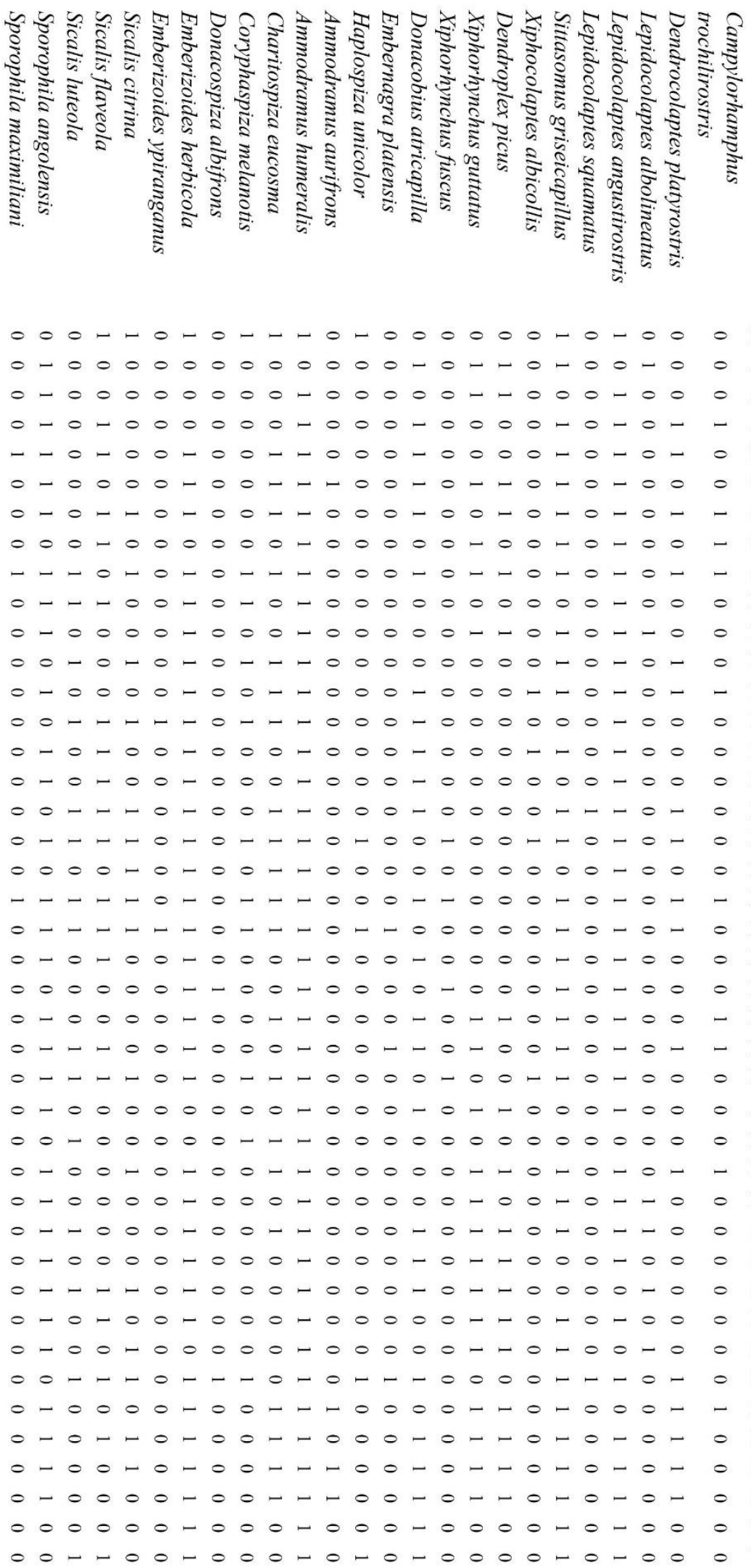

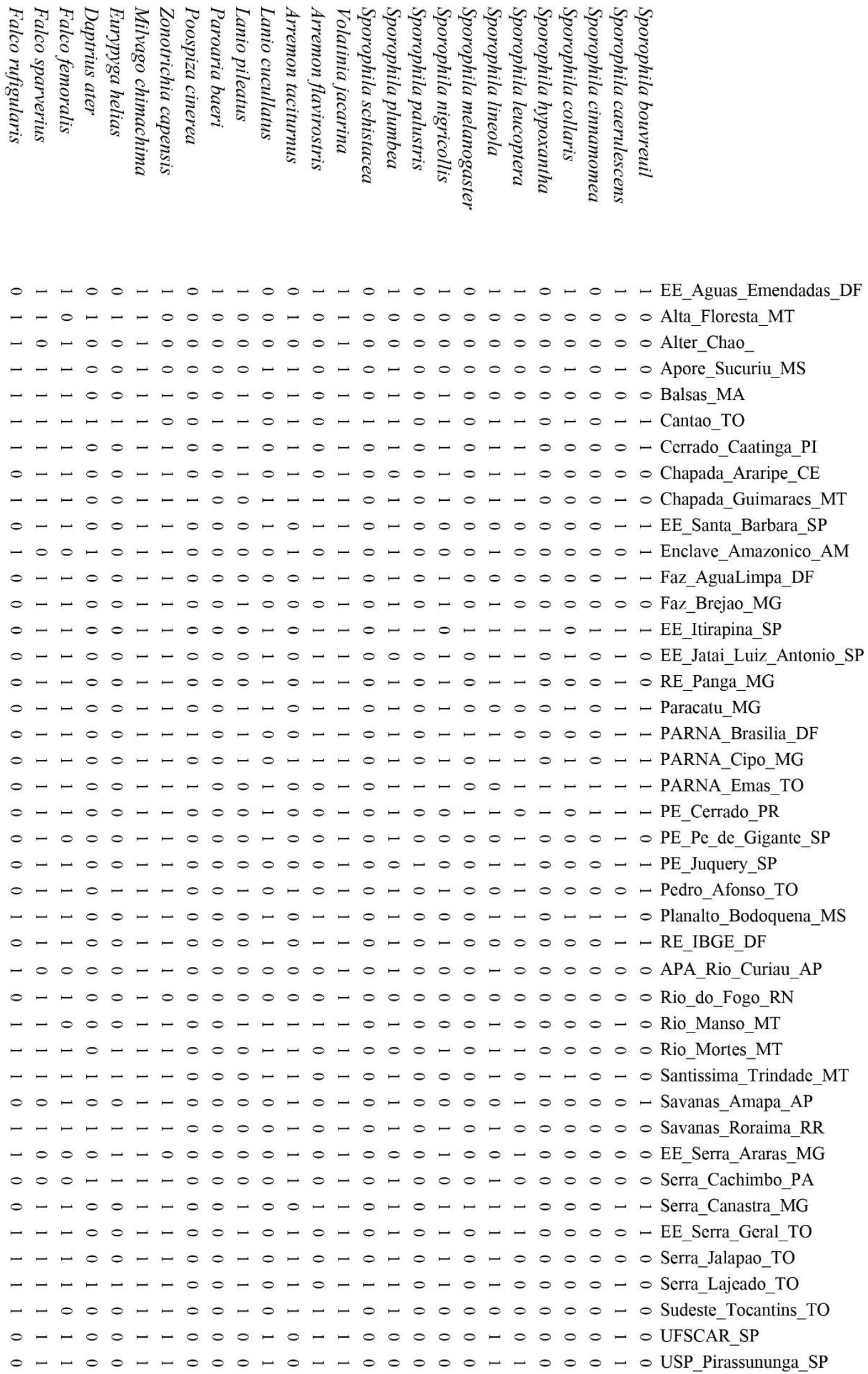

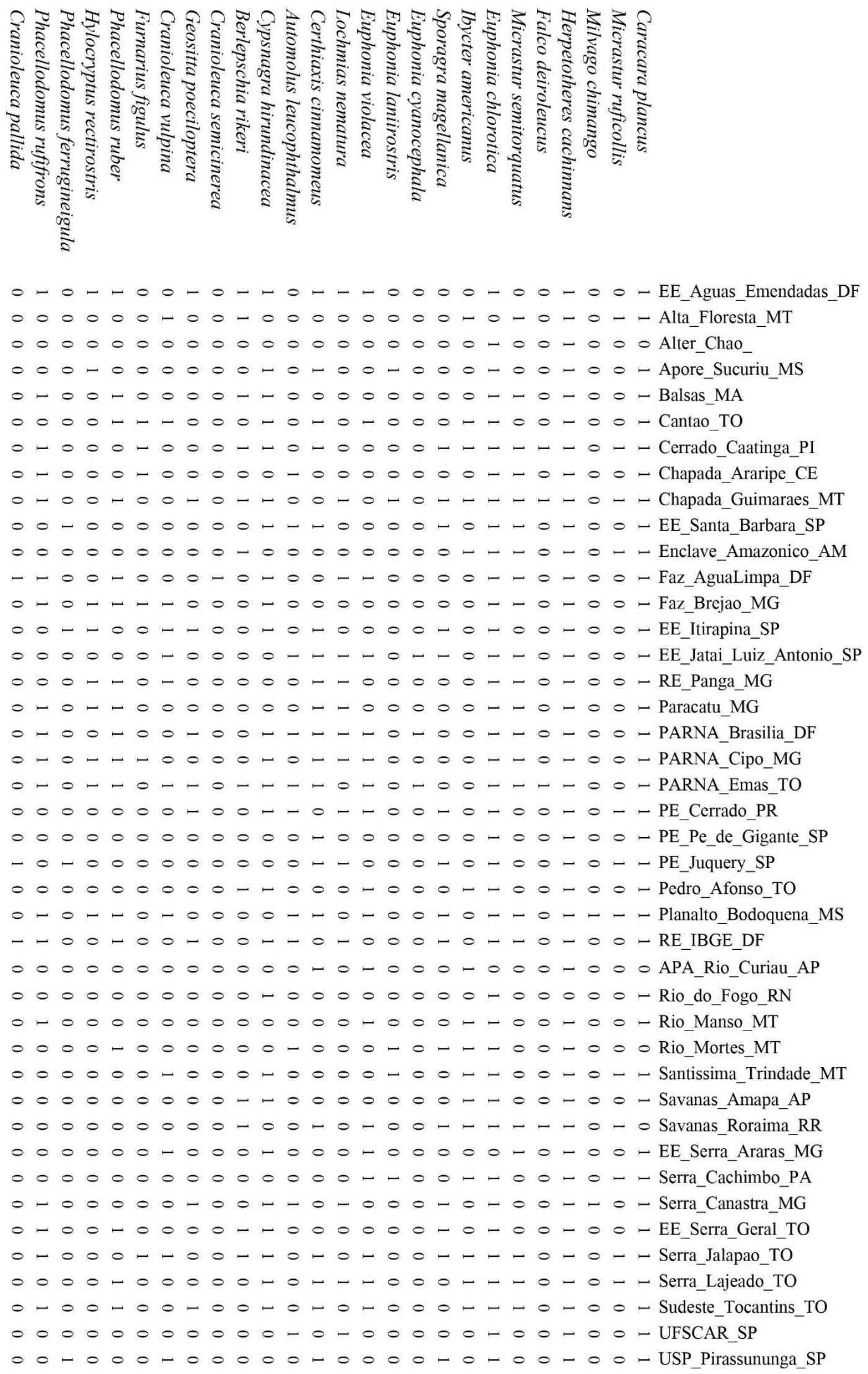

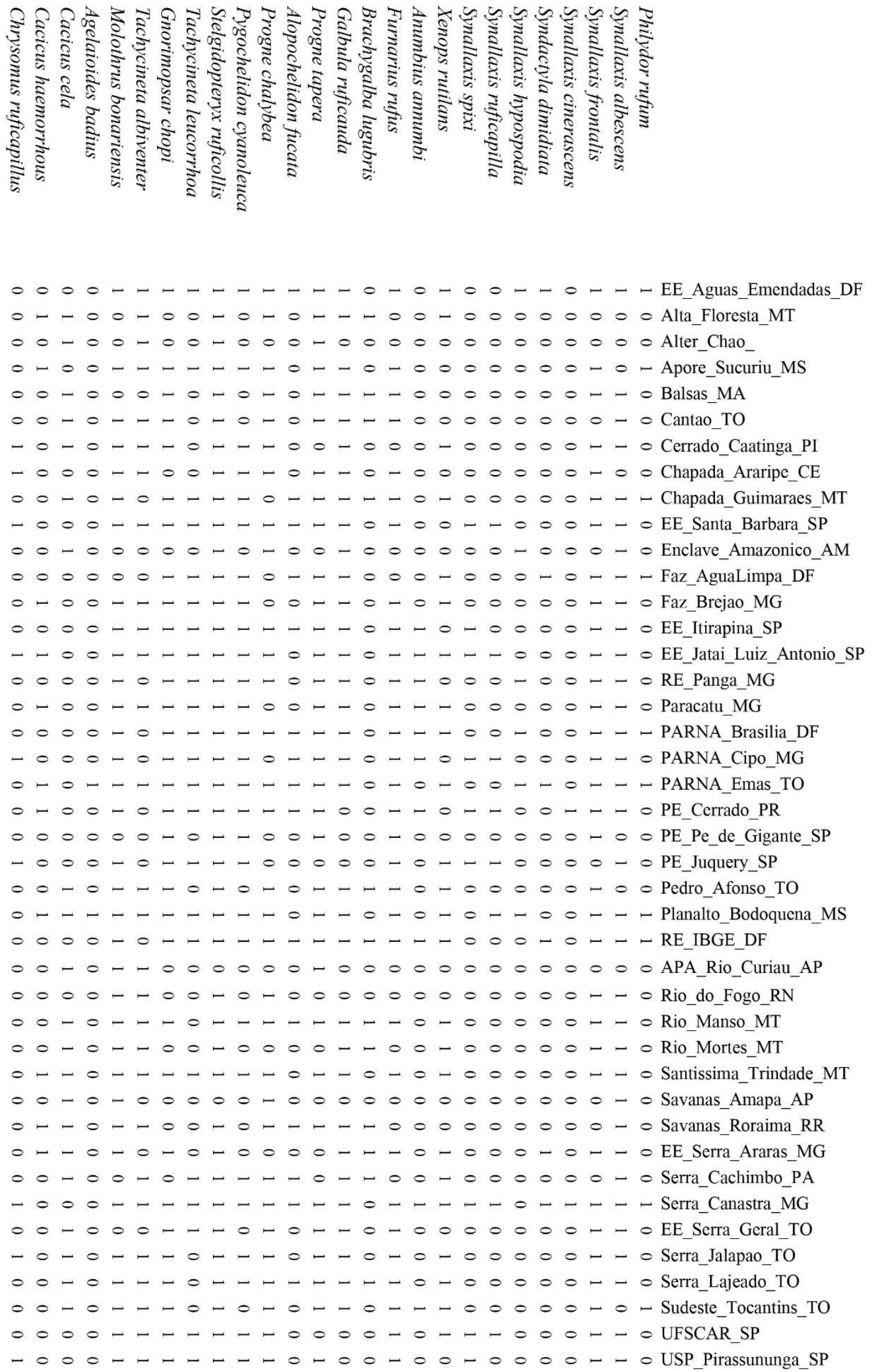

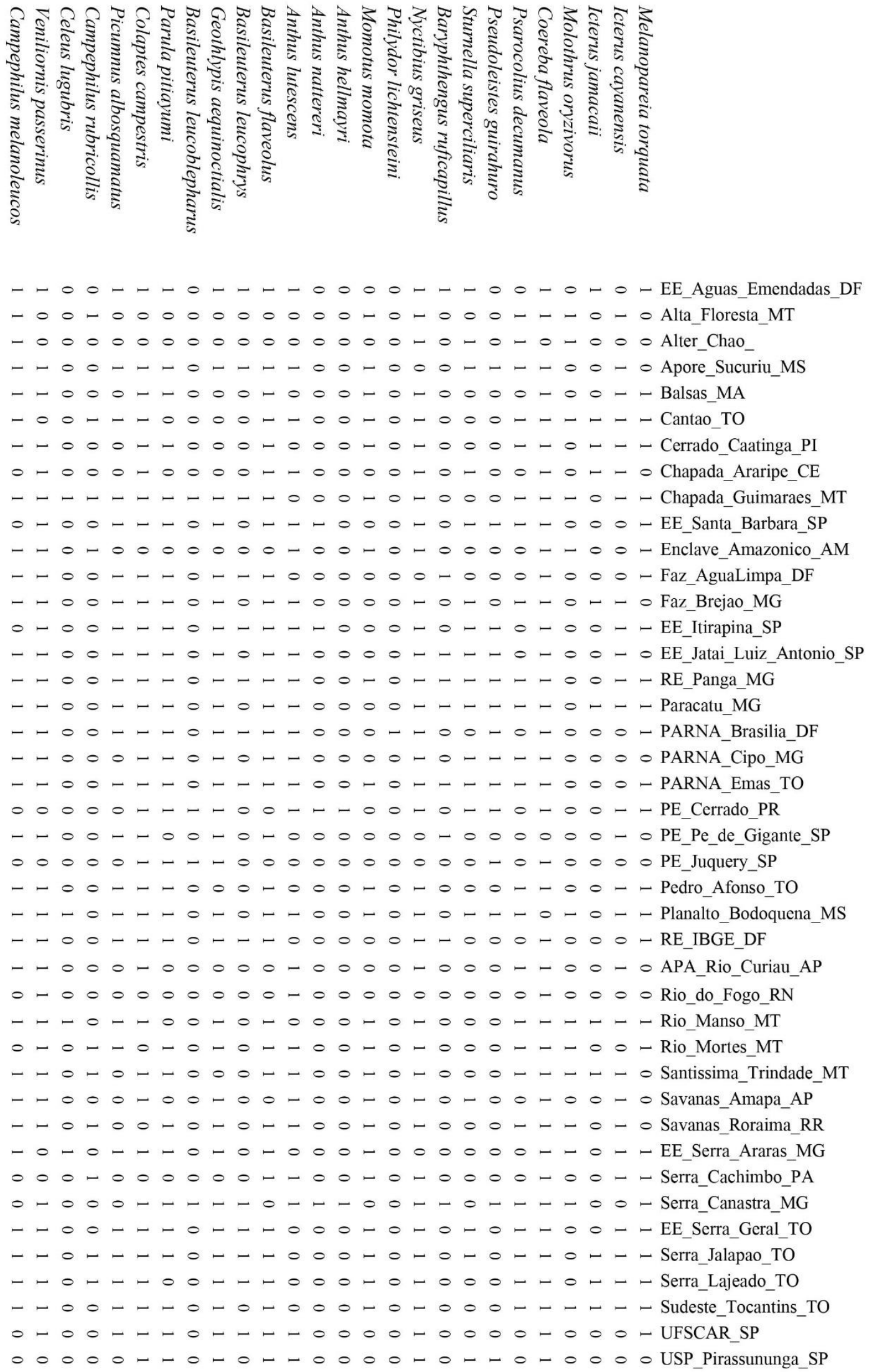

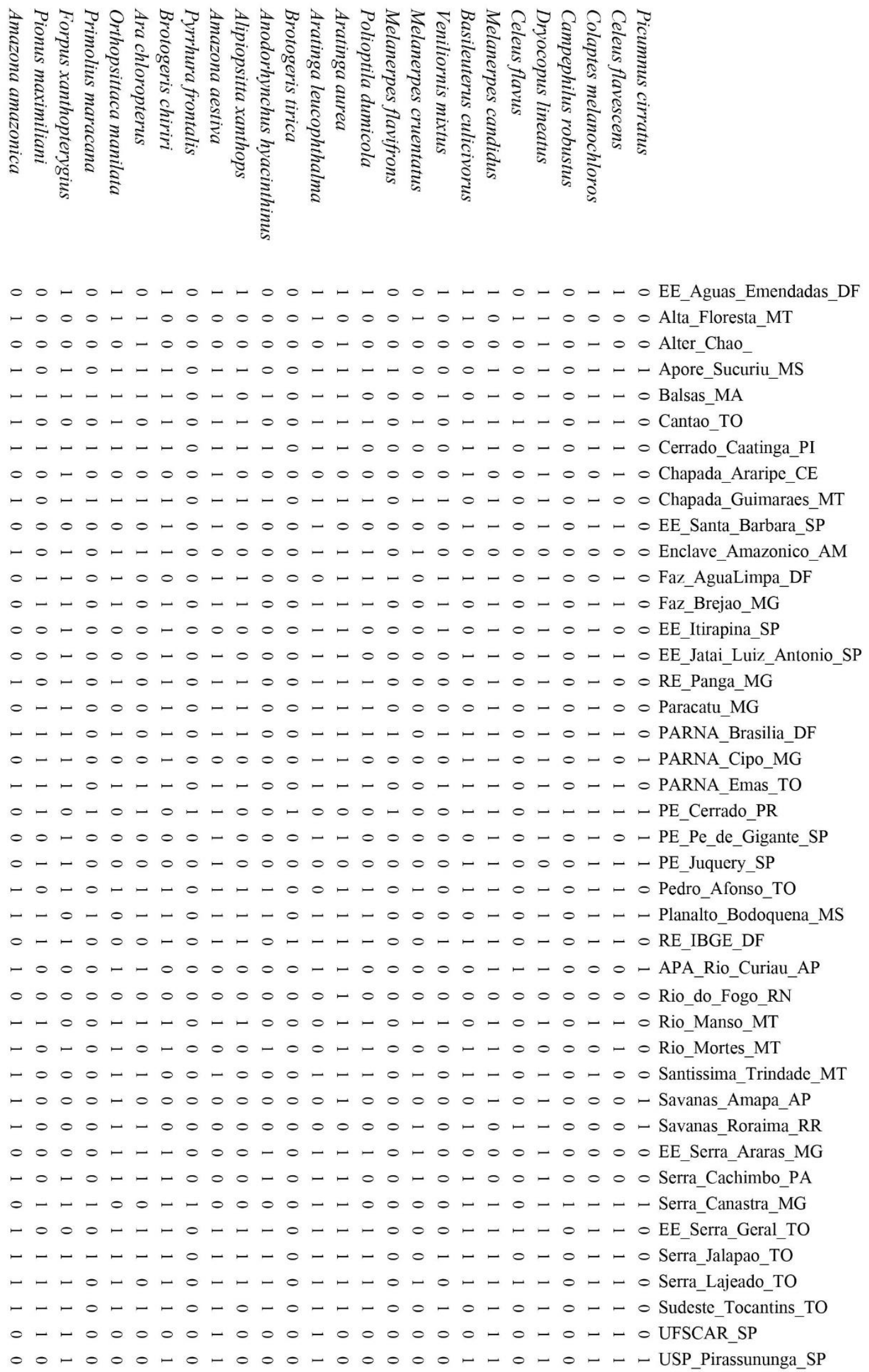

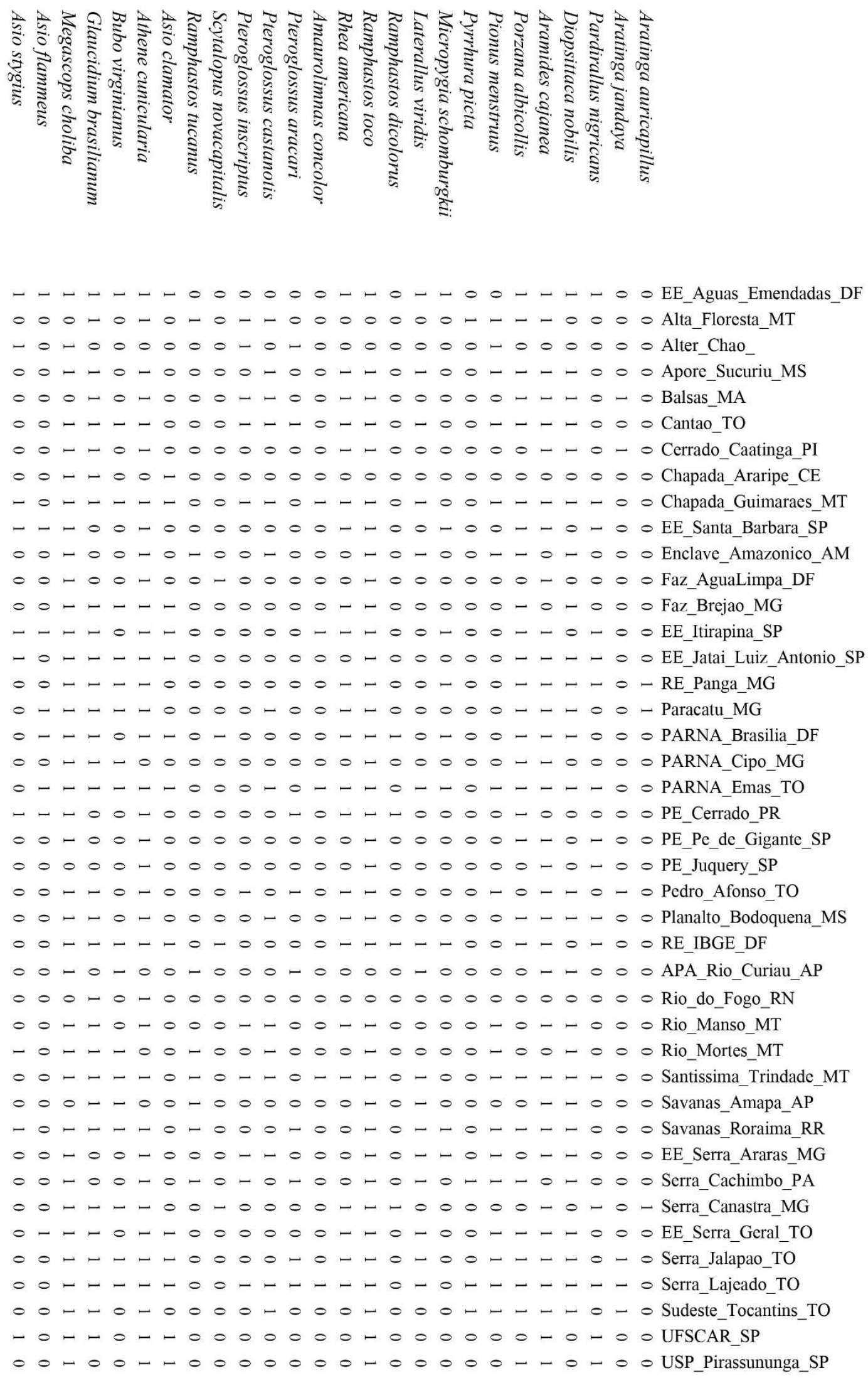

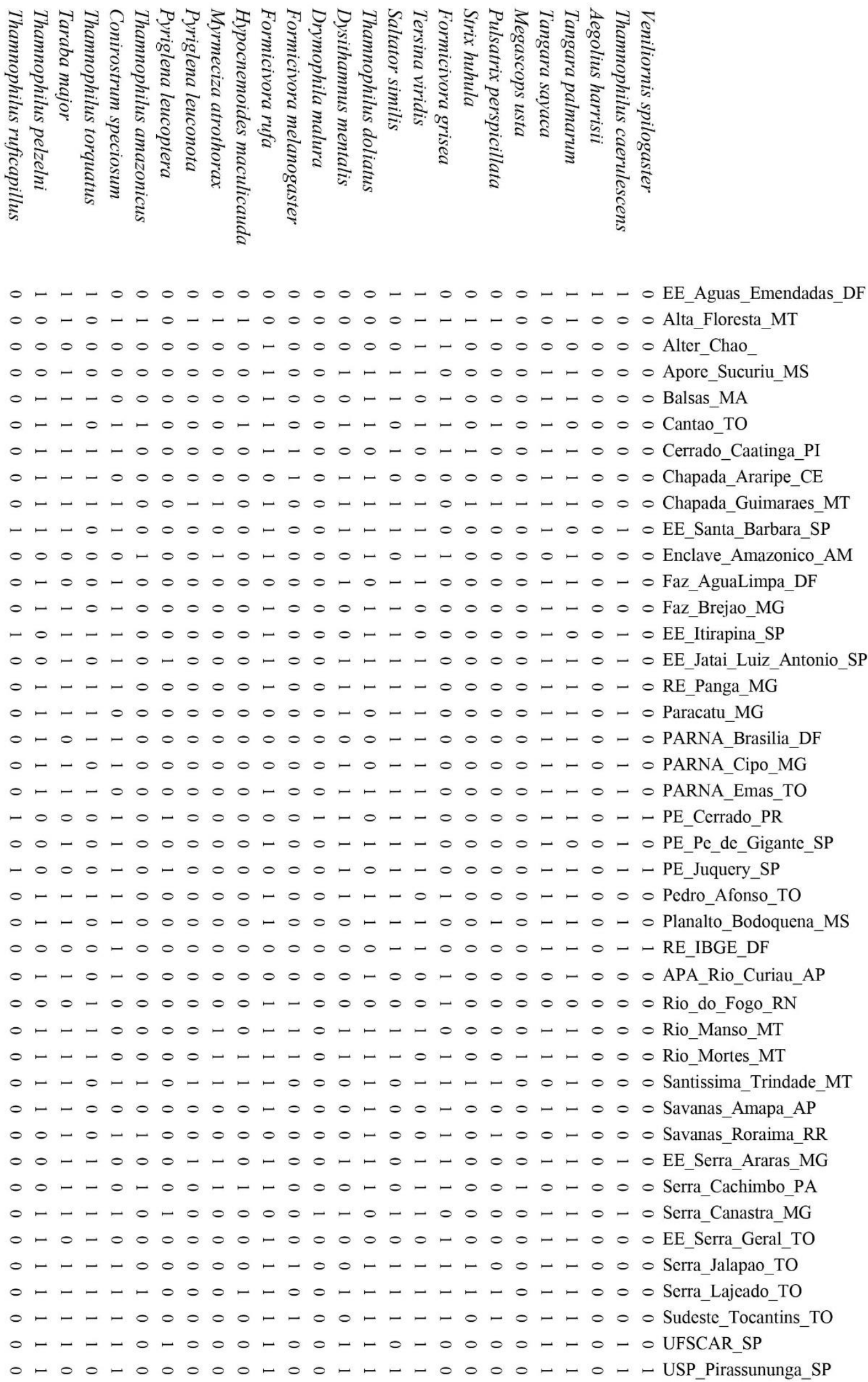

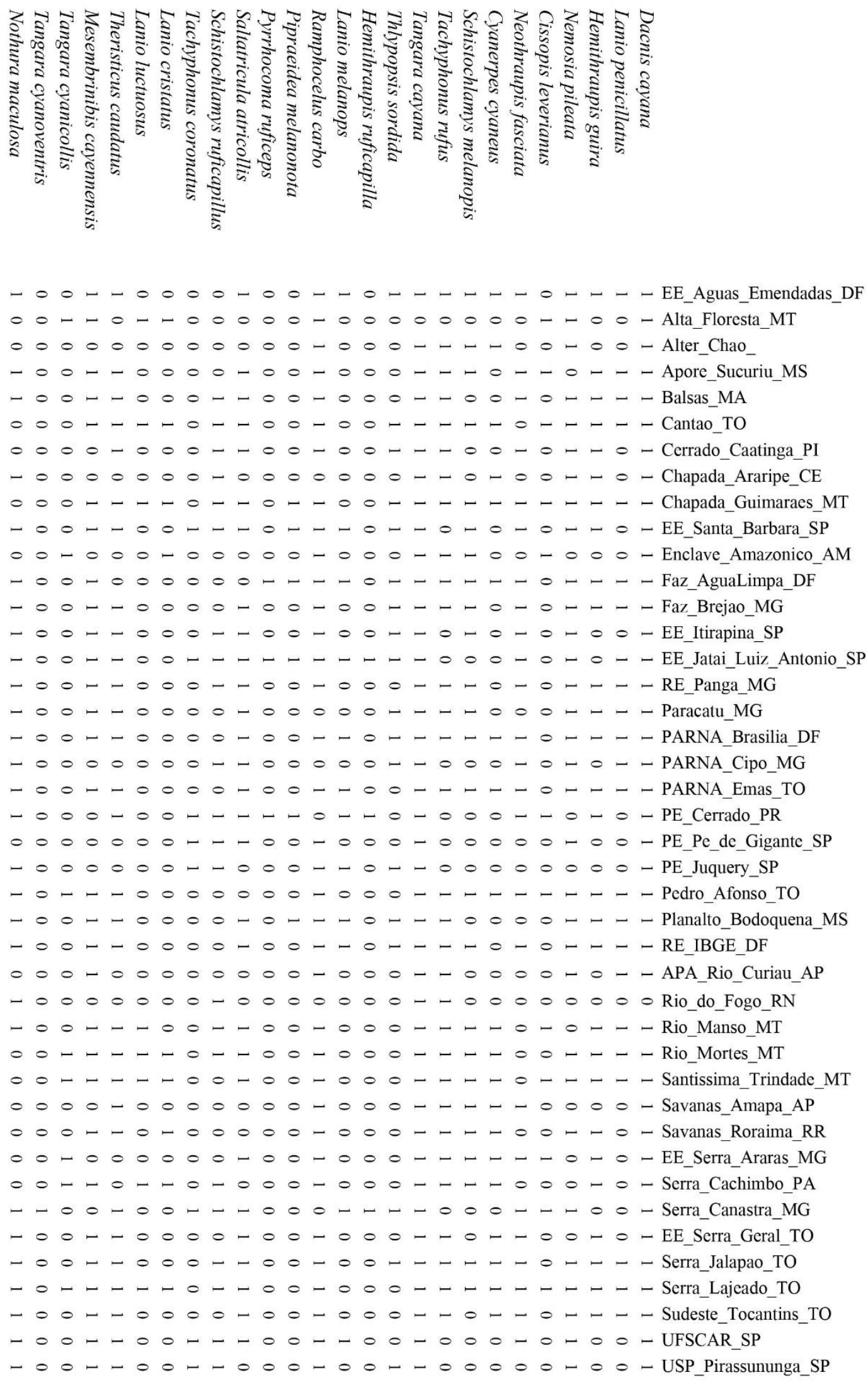

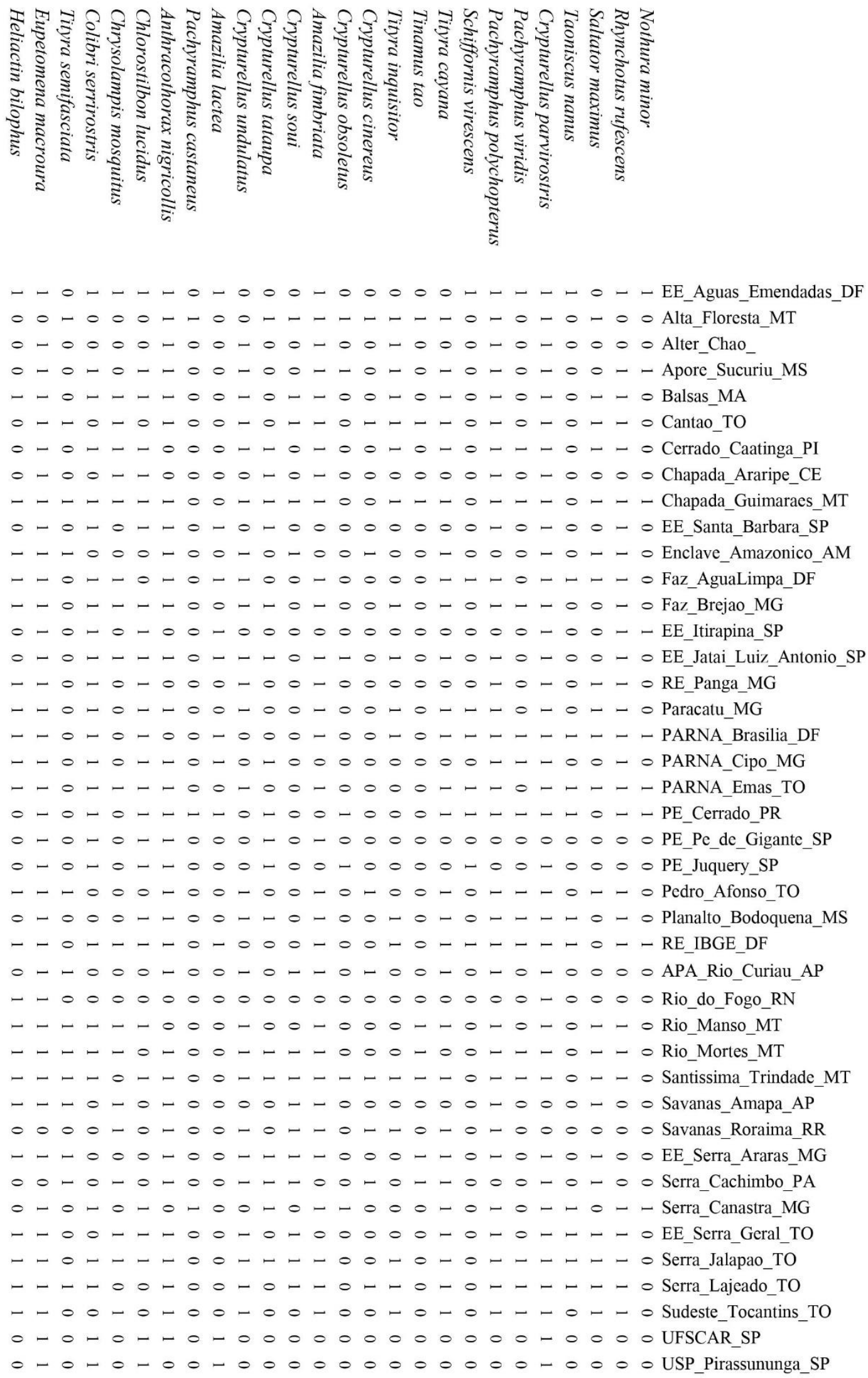

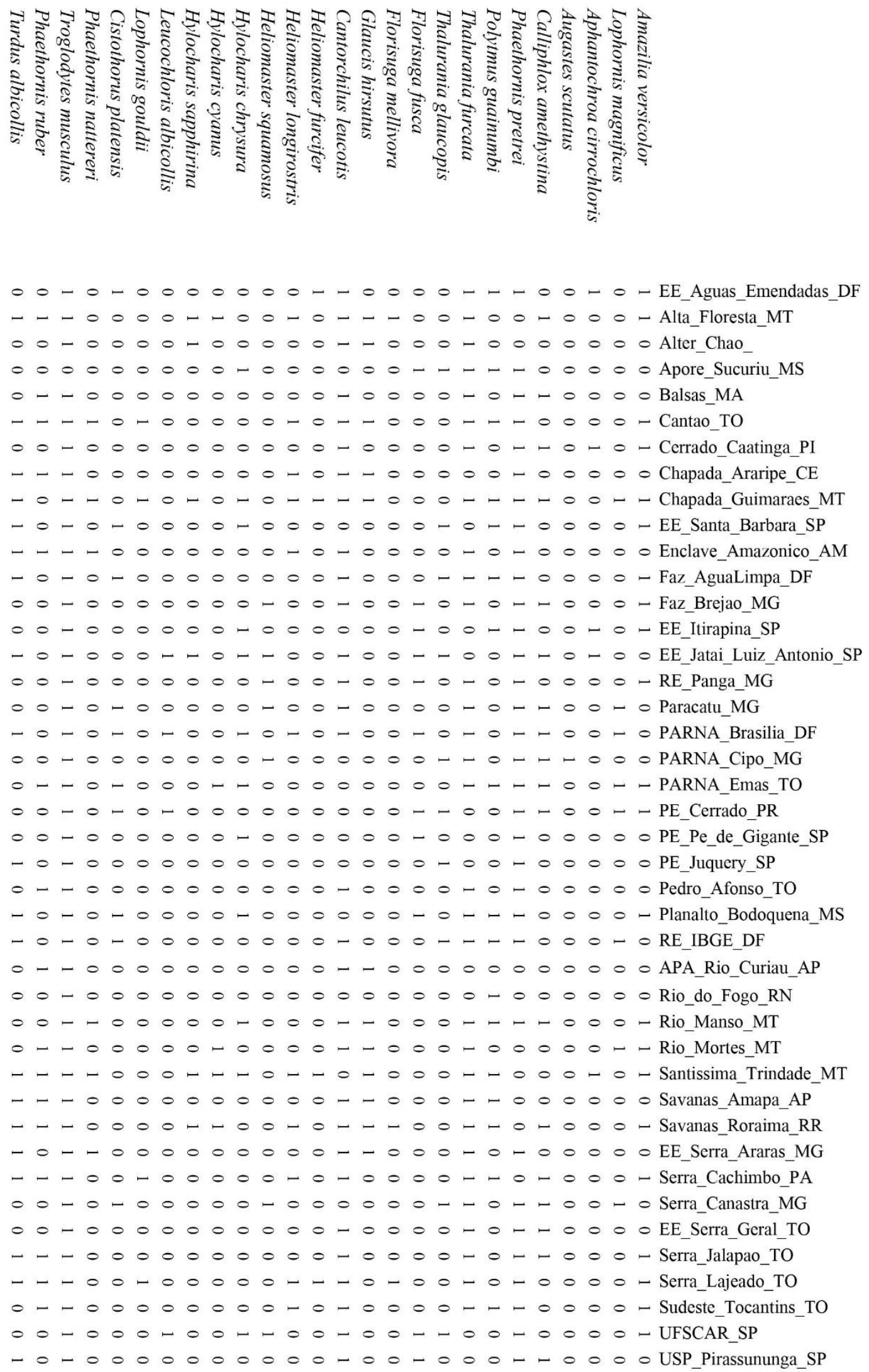


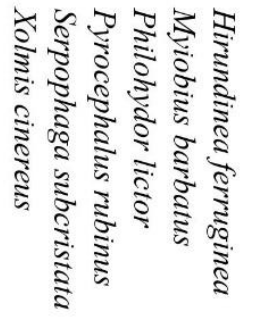

$---000$ o o - - - o 000000 - - - - 00 - o o - o - $0-100$ - - - - - - 00000 - o - - o - - - 000 - 000 - 0 - 000 - o- - - 0 - - 0000 - - - - - - 00000 - o - O - - $000-0$ - 0000 - $0-000$ - - - 0 - - - 000 - - 000 - 0000 - - o - O - - - - - - o o- 00 - 00000 - - - - - $000-0$ - o - - o - $000-0$ o $0-1-1$ - $00-00$ o $0-1-0$ - - - 00 - $00-00$ - 0 - - - - 0000 - $00-00$ - - - 00 - - - 000
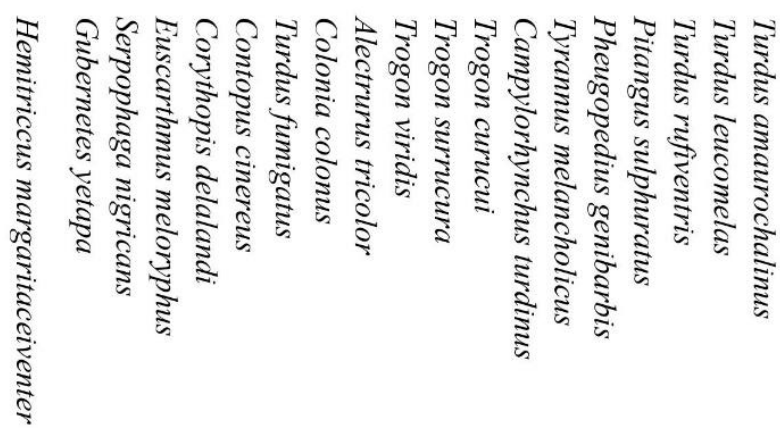

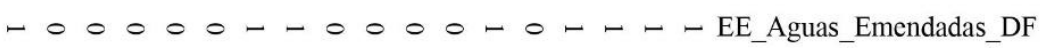

$00-00--0-0-----000$ Alta_Floresta_MT

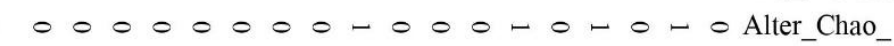

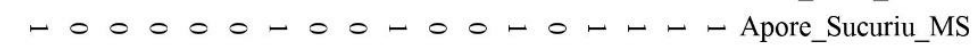

o $00-0$ o 0 o o - o - - - - - o Balsas_MA

o $-00-00-0-0---0--$ - Cantao_TO

$00-0-0-0-0-0-0----$ Cerrado_Caatinga_PI

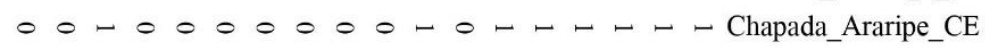

$-0------00--------$ Chapada_Guimaraes_MT

$-0--00--0000-0--1-$ - EE_Santa_Barbara_SP

0 ○ $000-0-0-0-1-0-0$ Enclave_Amazonico_AM

$-00--0--0-00-0----$ Faz_AguaLimpa_DF

- - $000-0-00-00-0----$ Faz_Brejao_MG

$--00000-0000-0----$ EE_Itirapina_SP

$-0---0-00-00-0----$ EE_Jatai_Luiz_Antonio_SP

- $000-0-00000-0-\cdots--$ RE_Panga_MG

$-00-00-00-00-0----$ Paracatu_MG

$-00-----0000,----\cdots-$ PARNA_Brasilia_DF

- 0 0 0 0 0 0 0 0 0 0 - 0 - - - - PARNA_Cipo_MG

$--0--0--0000-0----$ PARNA_Emas_TO

$---0-0--0-00-0----$ PE_Cerrado_PR

$-00000-00-00-0----$ PE_Pe_de_Gigante_SP

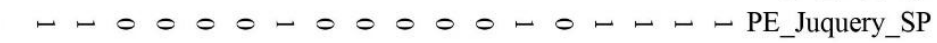

- 0 0 0 0 - 0 0 0 - o - - - - - - Pedro_Afonso_TO

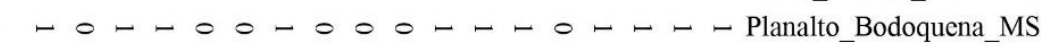

$-0---0--0000-0----$ RE_IBGE_DF

$0000--00-000-0-0-0$ APA_Rio_Curiau_AP

- o o- $00000000-0-0-0$ Rio_do_Fogo_RN

- o - - o o o o o - o - - - o - - Rio_Manso_MT

- o- - - o- o- o- o- - - - - o Rio_Mortes_MT

$00-00--0-0----\cdots---$ Santissima_Trindade_MT

$00000000-000-0$ - 0 - 0 - 0 - Savanas_Amapa_AP

○ $00-0-0-0$ - 0 - 0 - 0 - o Savanas_Roraima_RR

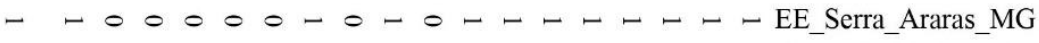

- 0 0 0 - o- 0 - $-0-0---0--$ Serra_Cachimbo_PA

- - - $-0,0--0-00-0----$ Serra_Canastra_MG

- $00-000000000--$ - 0 - - - EE_Serra_Geral_TO

- $0----0-0$ - $0-0-----$ - Serra_Jalapao_TO

- $000-00-0-0-0--\sim 0--$ Serra_Lajeado_TO

- $00---0-000-0------$ Sudeste_Tocantins_TO

- - $00000-00000-0---$ - U UFSCAR_SP

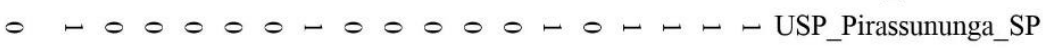



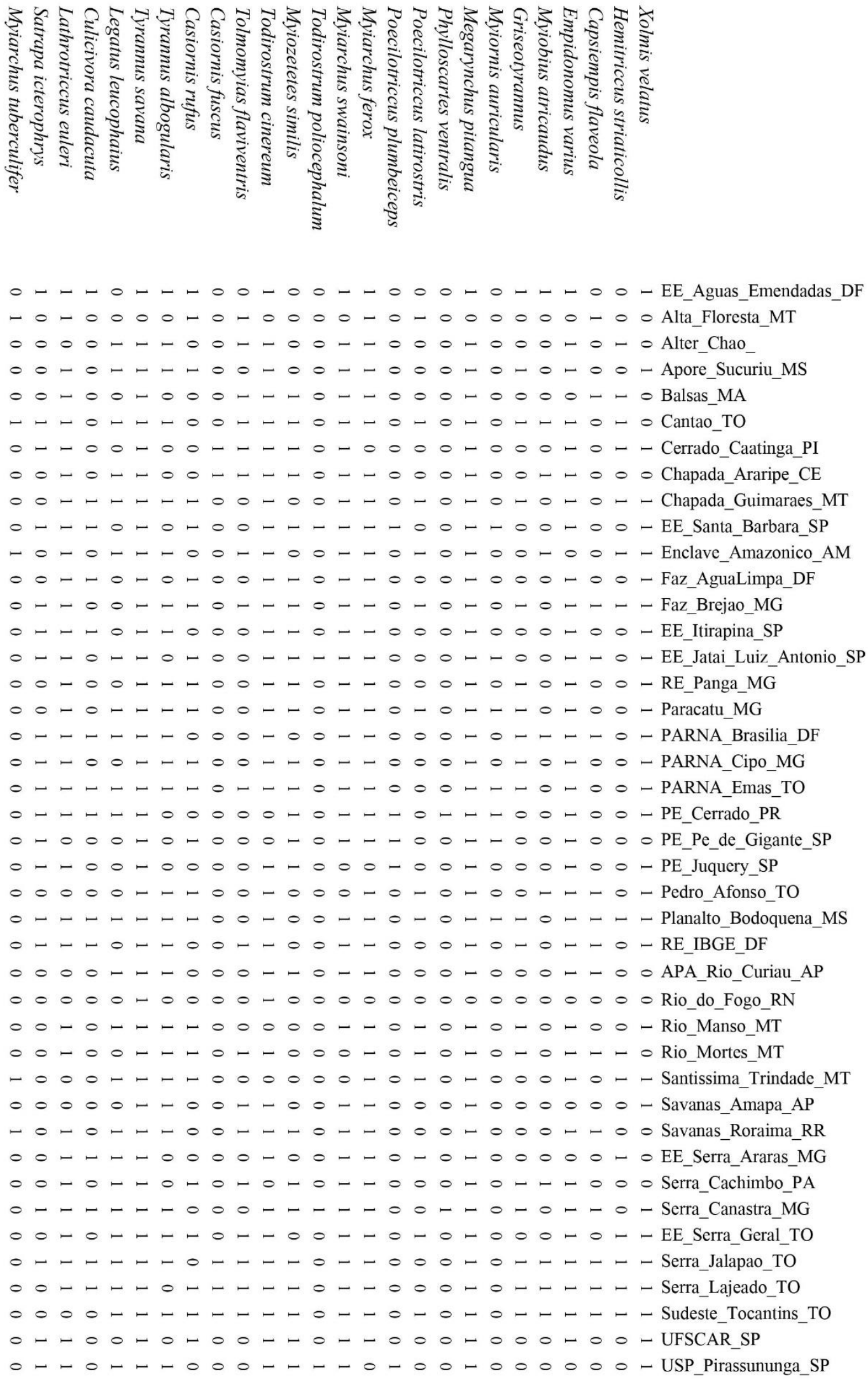

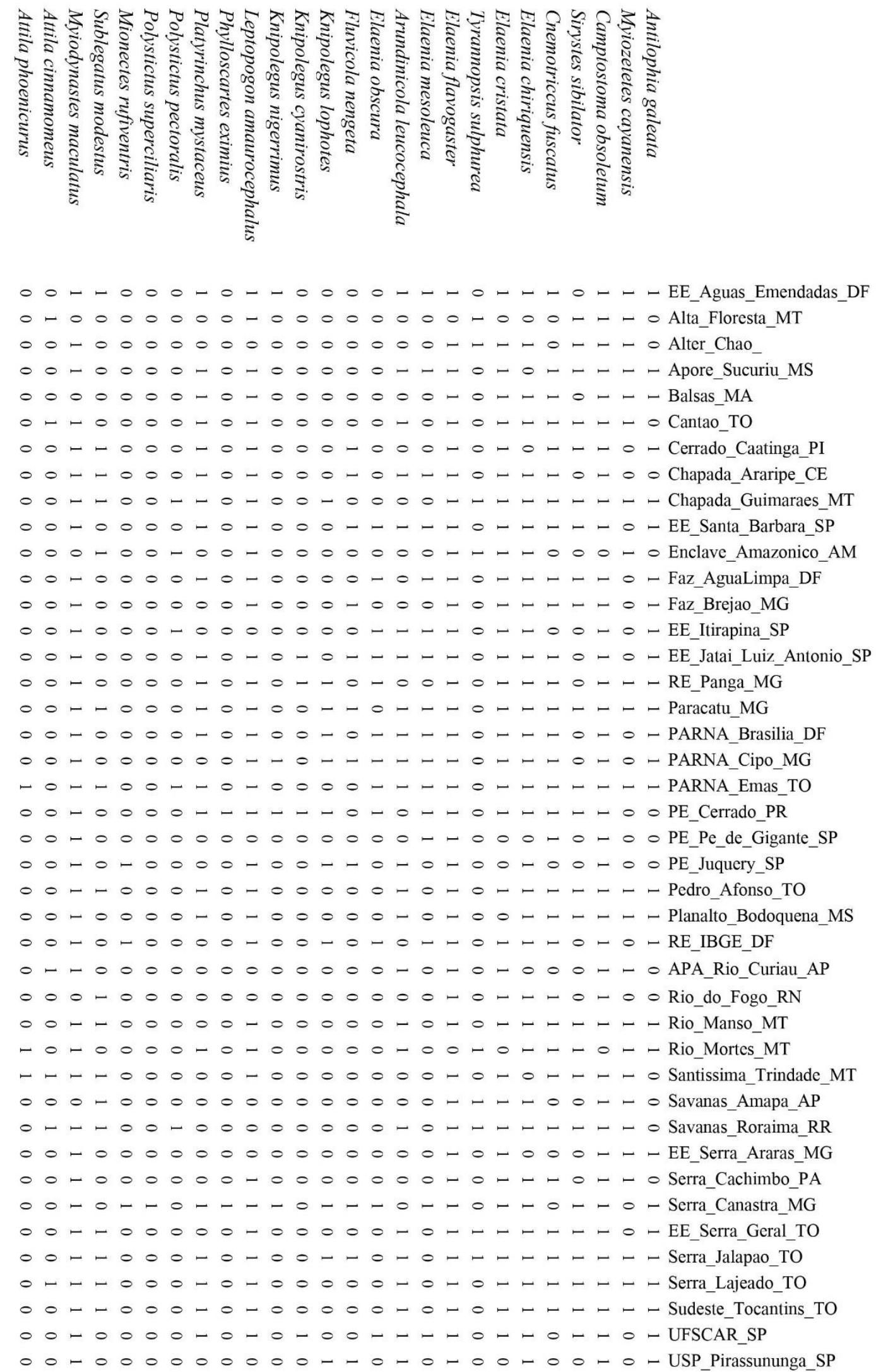

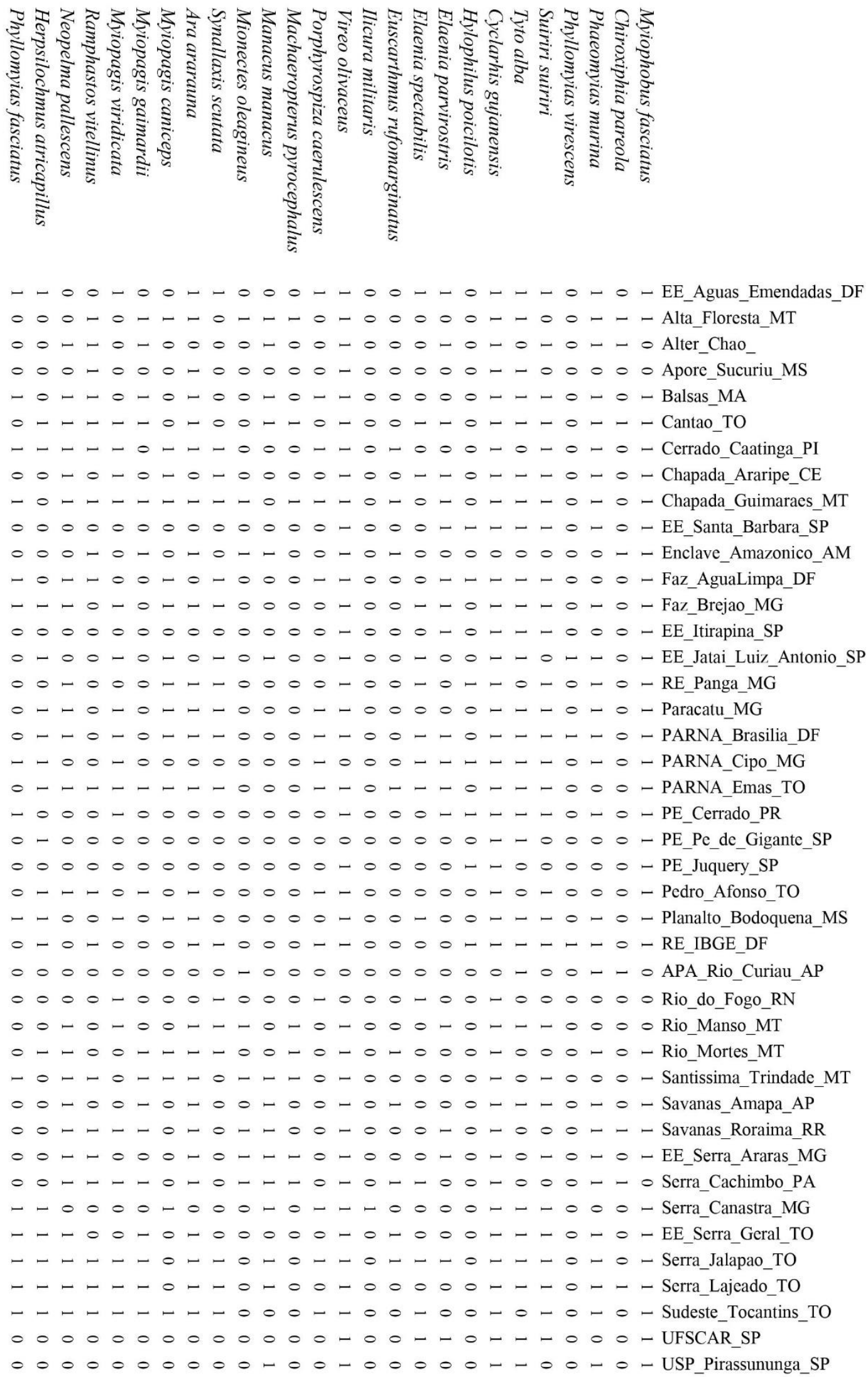

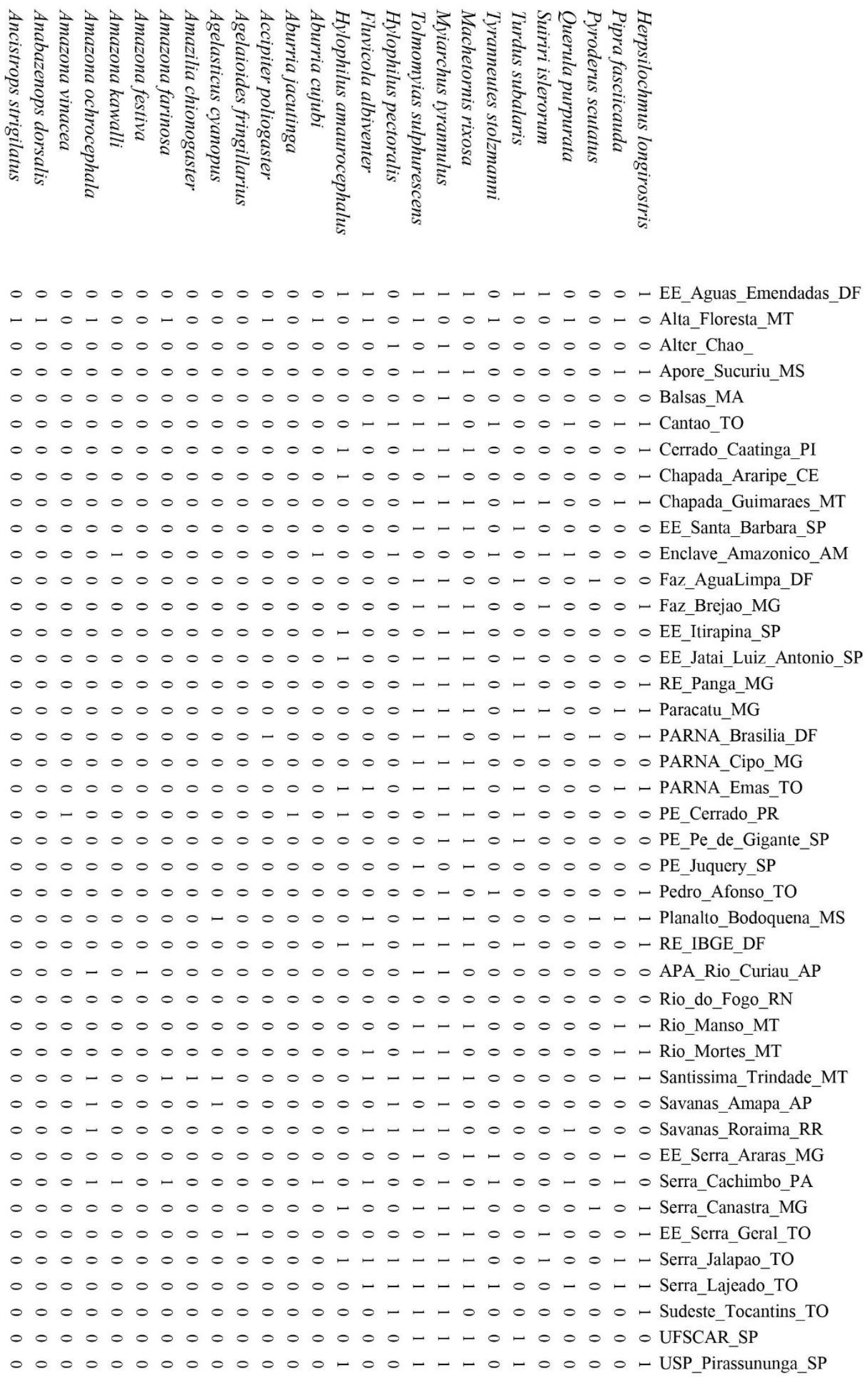

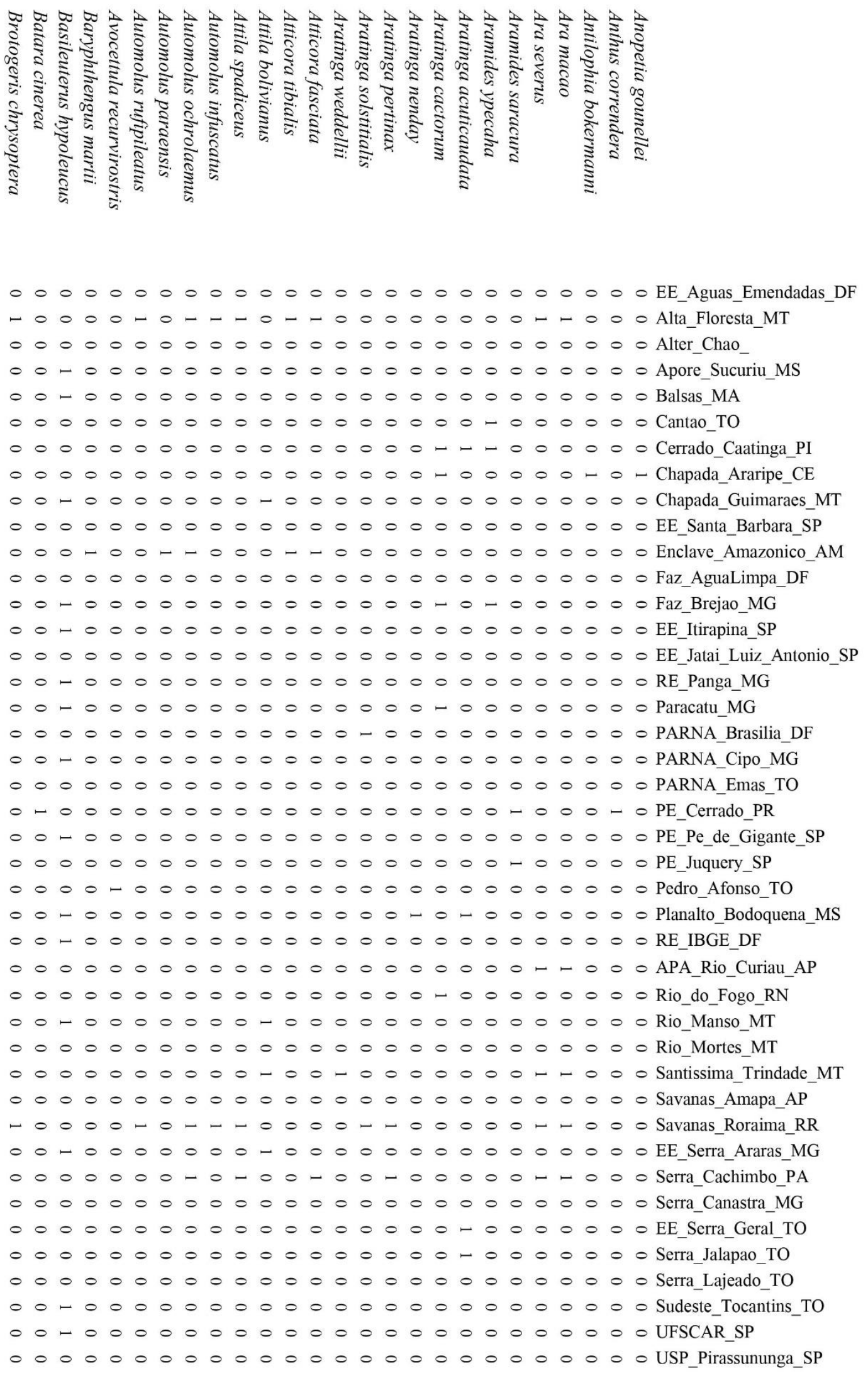


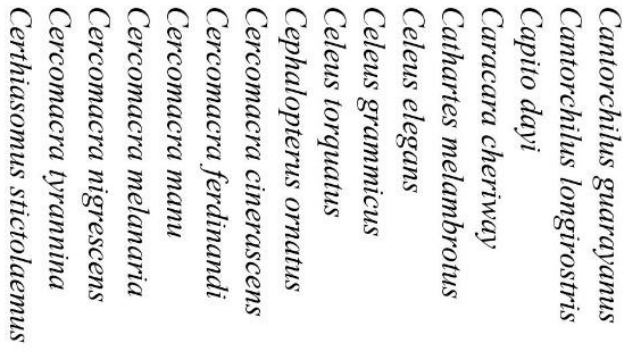

0000000000000000 - o- $-0-0-1-1-1-0-0$ - $0000000001-000$ - 00000000000000 - 00000000000000 - $0000-00-0000000$ - $000000000000-0$ - $000000000000-0$ - 000000010000000 - o o o o o o o o o o o o 00 - o- 000 - 00 - 0 - 0000 - 000000000000000 - 000000000000000 - 00000000000000 - o o o o o o o o o o o o - 00000000000000 - 00000000000000 - 0 o o o o o o o 000000 - o o o o o o o o o o 0000 - 00000000000000 - 00000000000000 - 000000000000000 - 00000000000000 - 00000000000000 - 0 - 000000000001 - 00000000000000 - $00000000-0-000$ - $0000000000000-0$ - $0000001-0000000$ - 000000000000000 $00-000-1-1-00001$ - -00000000100000 - -0000 - 0 - $-0-1-1-000$ $00-0000000-00000$ - o- 000 - $-1-0-10000$ - o o o o o o o o o o o l - 00000000000000 - 000000000000000 - 000000000000000 - 000000 - 0000000 - 00000000000000 - 00000000000000

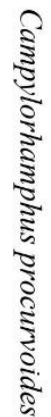

○ -

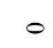




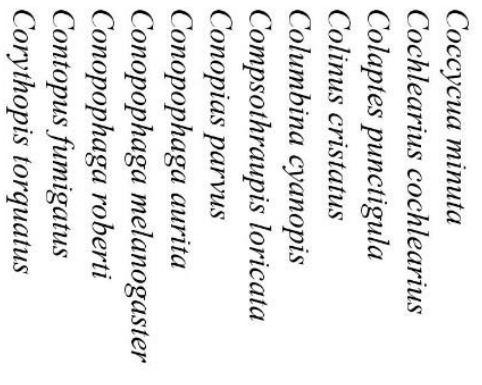

000000000000 - 00 - - 000000 - 0000000000 - 0000000000 - -000000000 - 00000 - 000 - $0000-00000$ - 0000000000 - 0 o o o 0000 000000000000 - o o - O - o 0 0 0 0 0 - o o o o o o 0000 - 0000000000 - 0000000000 - 0 o o 0 o 00000 - 0000000000 - 0000000001 - 0000000000 - 0000000000 - 0000000000 - 0000000000 - 0000000000 - 0 o 00000000 $0-0000000000$ 000000000000 - 0000000000 o $0000-00-1-0$ - 0000000000 - 0000000000 - 0 o o o o o 0000 - 000000000 - $0000000-1-1$ - o 000 O 0 O - - $00000-0000$ - 0000000000 - 0000000000 - 0000000000 - $00000-000-0$ - 0000000000 - 0000 - 00000 - o 000000000 - 0000000000

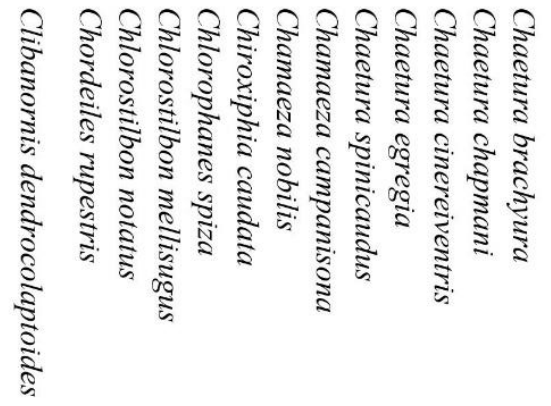

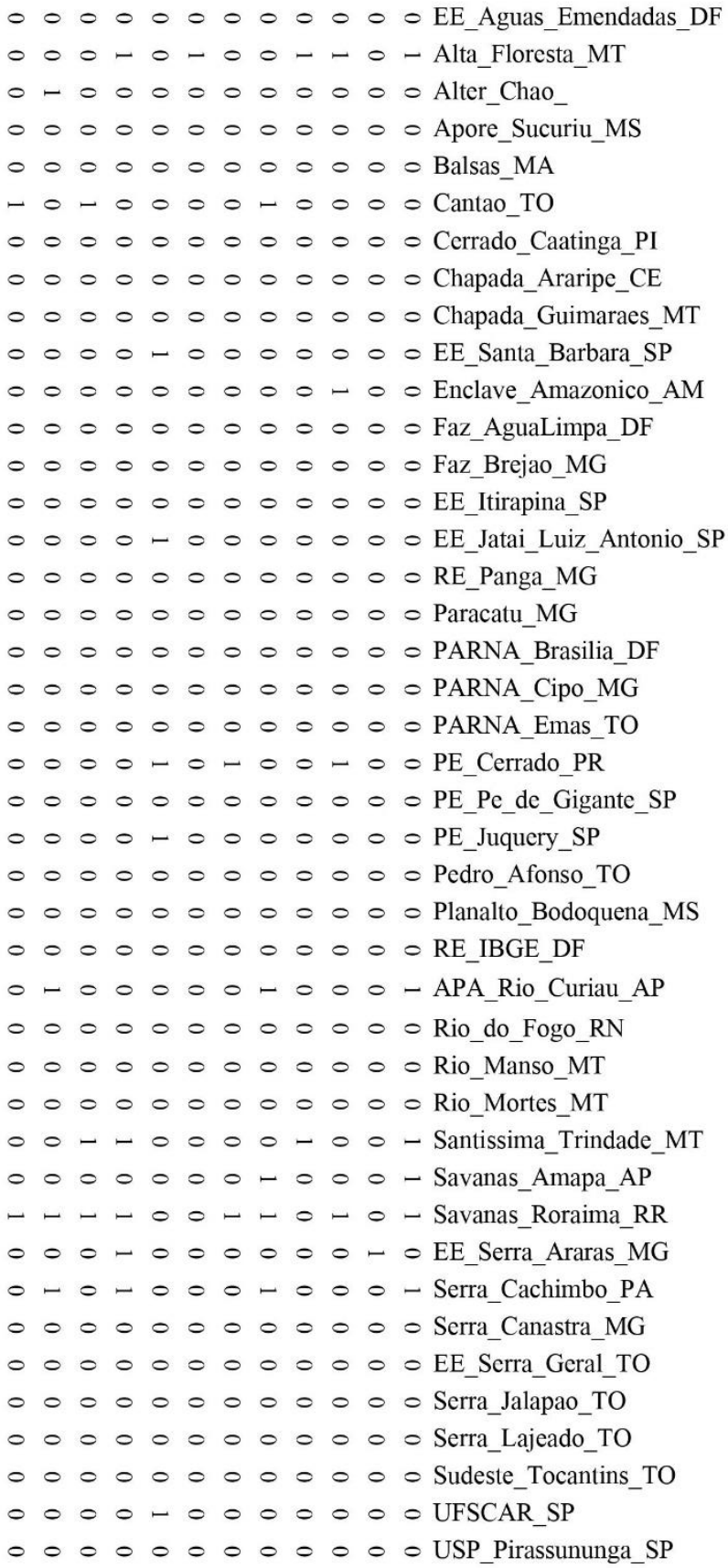



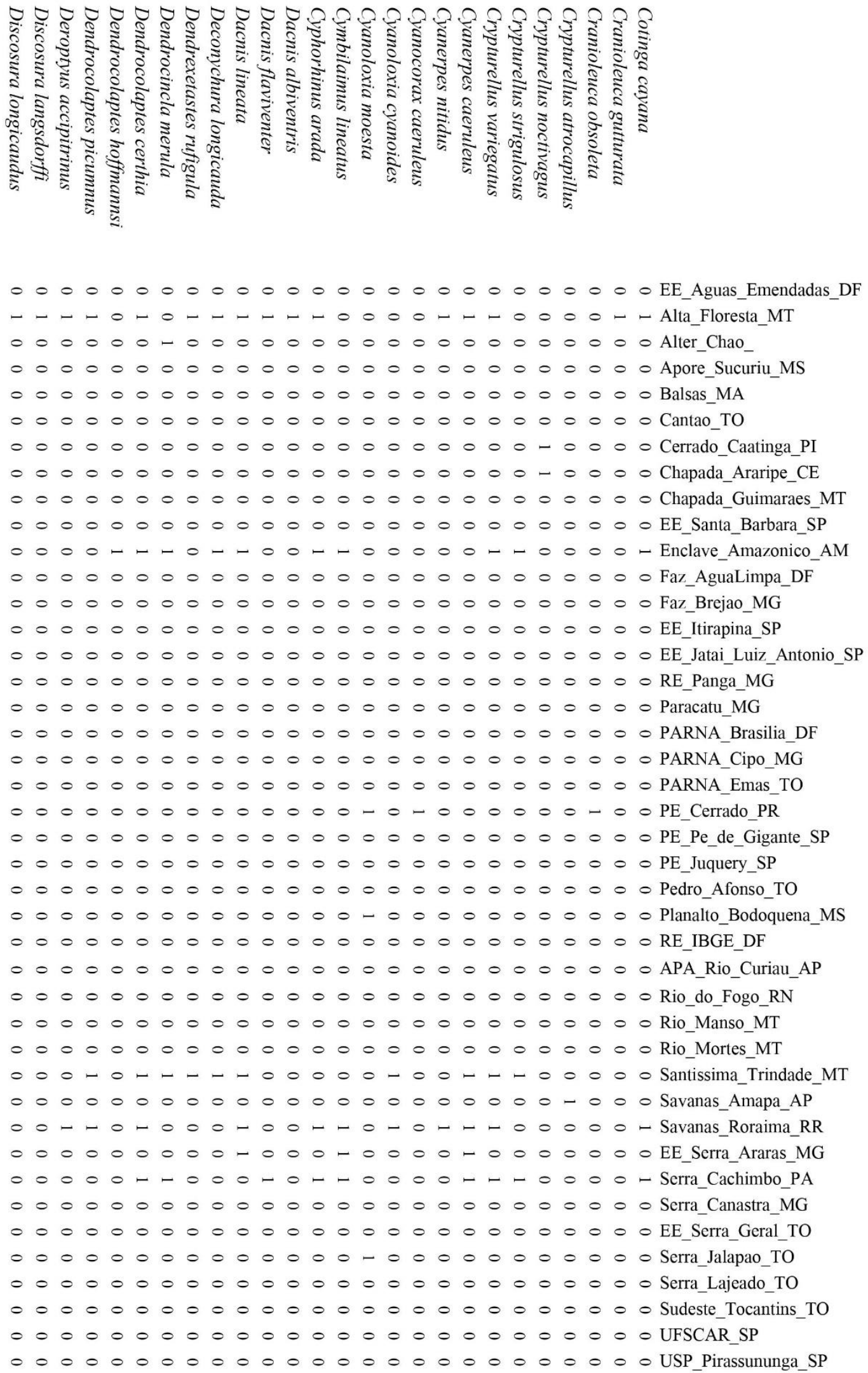

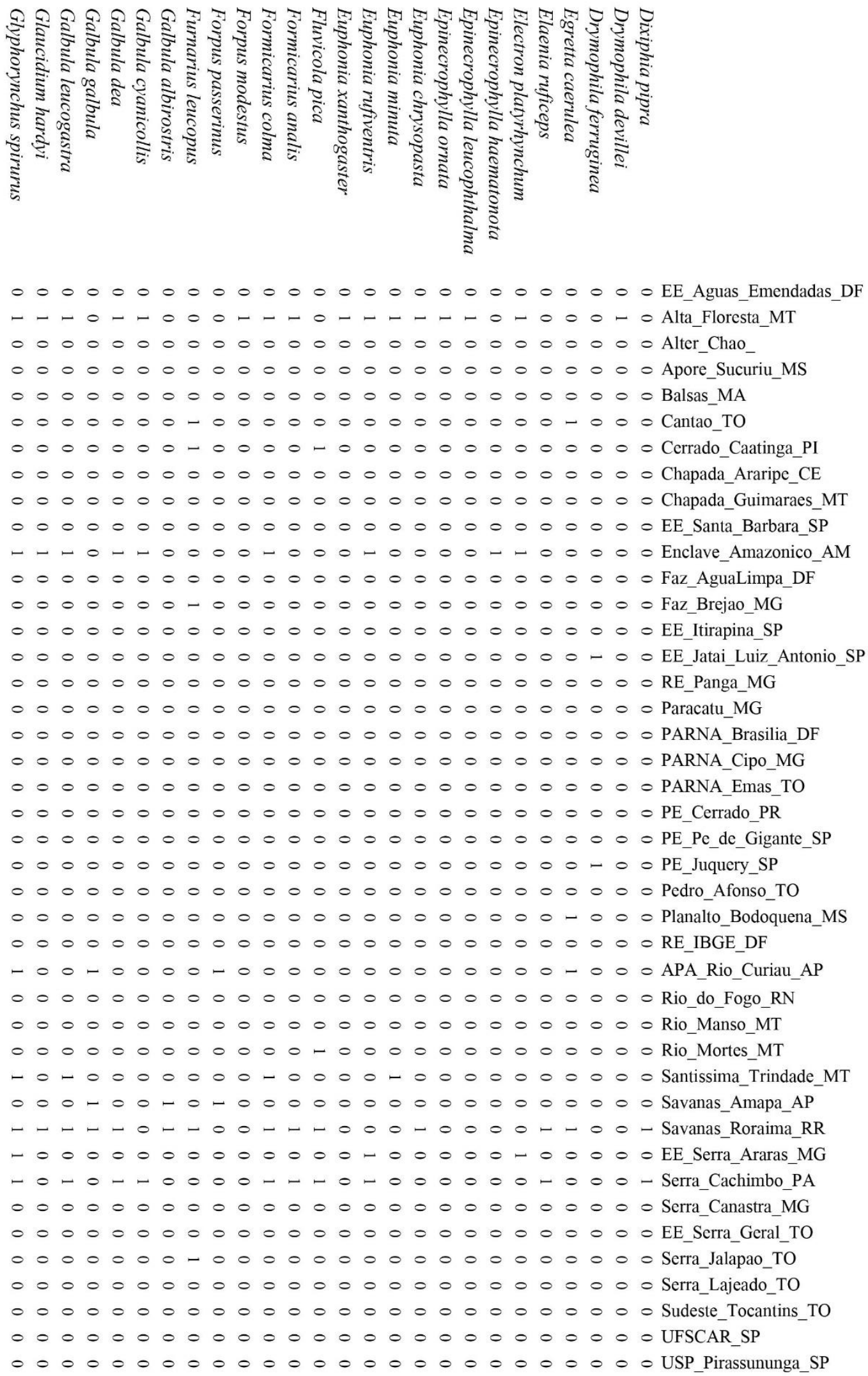

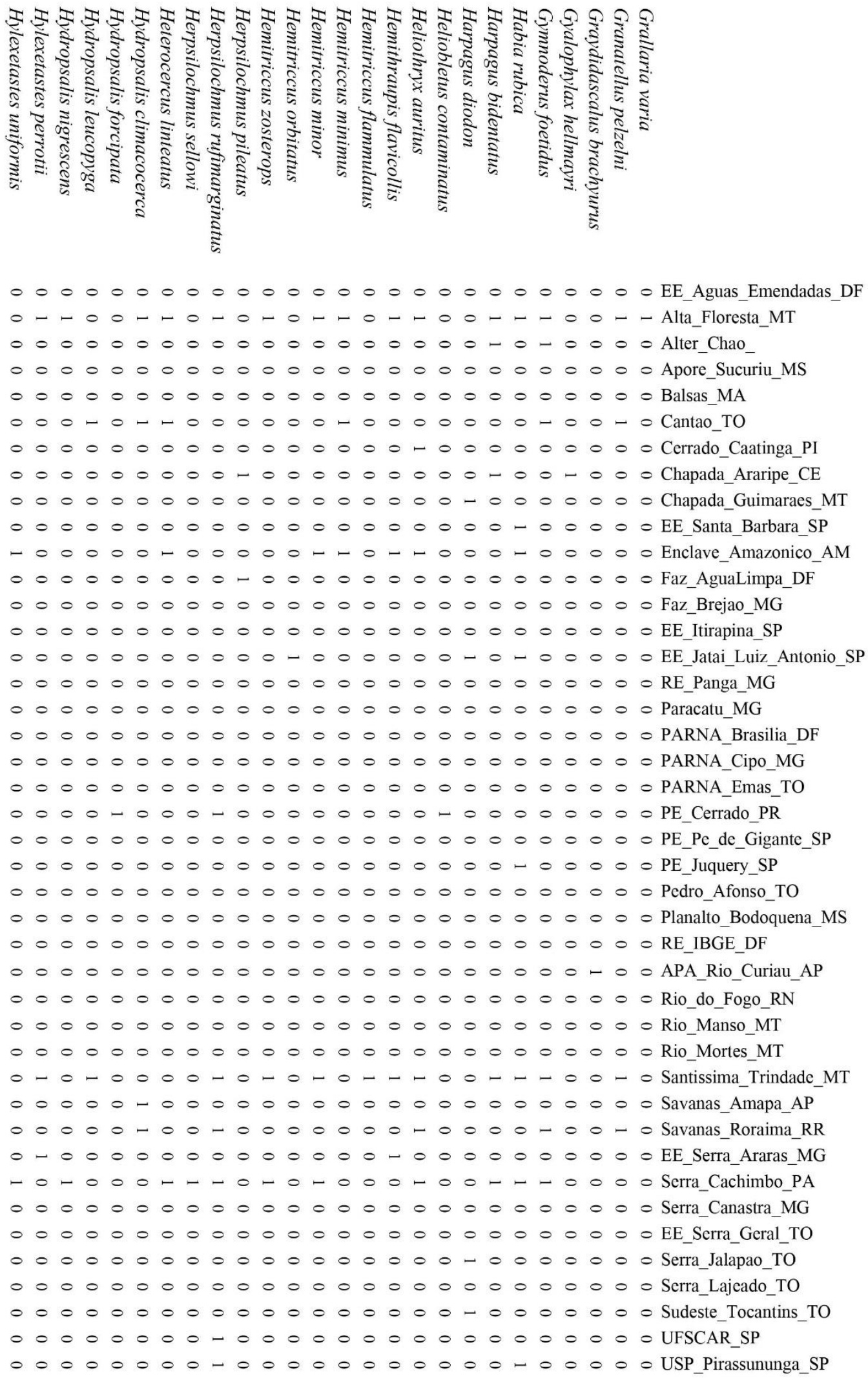

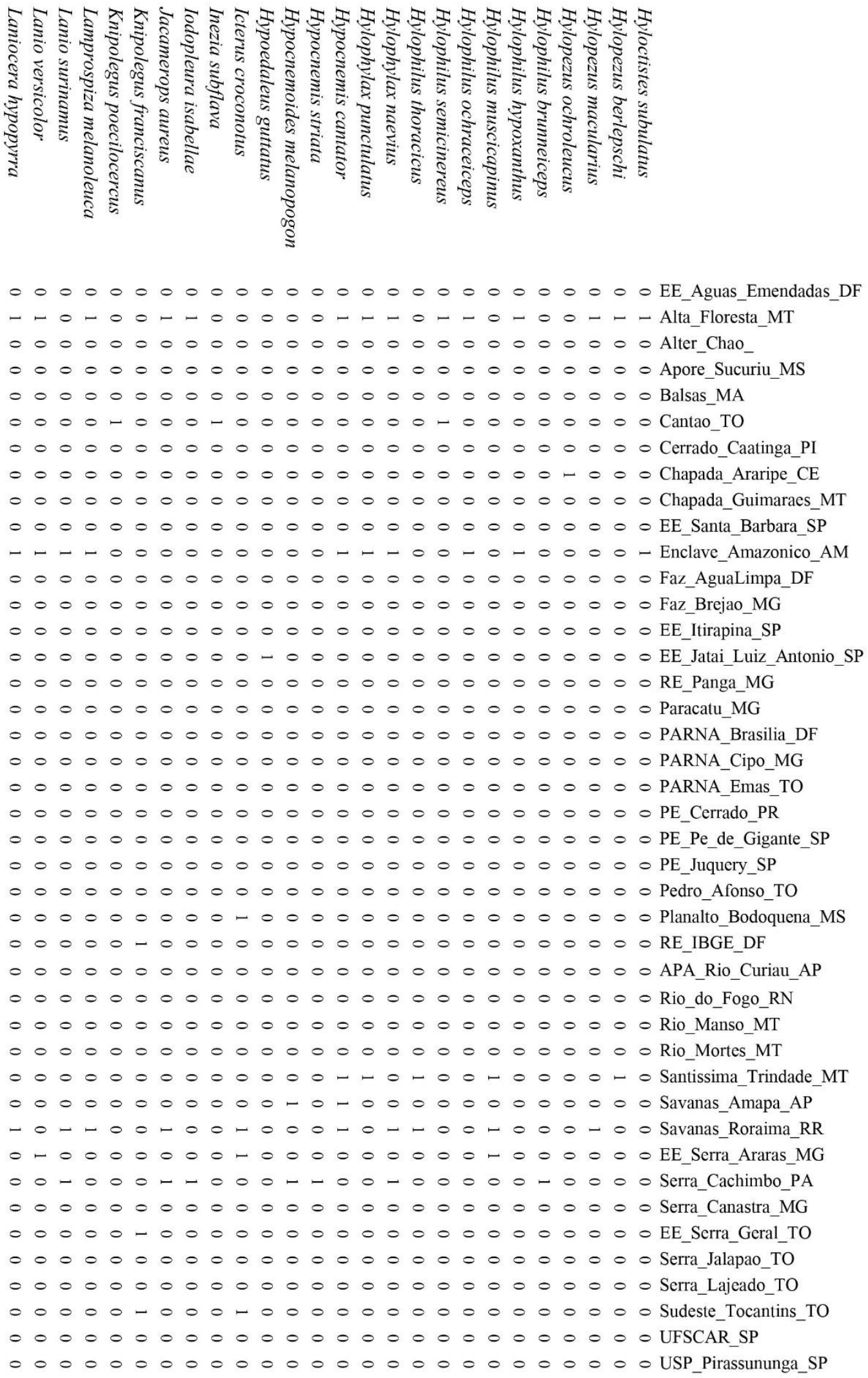

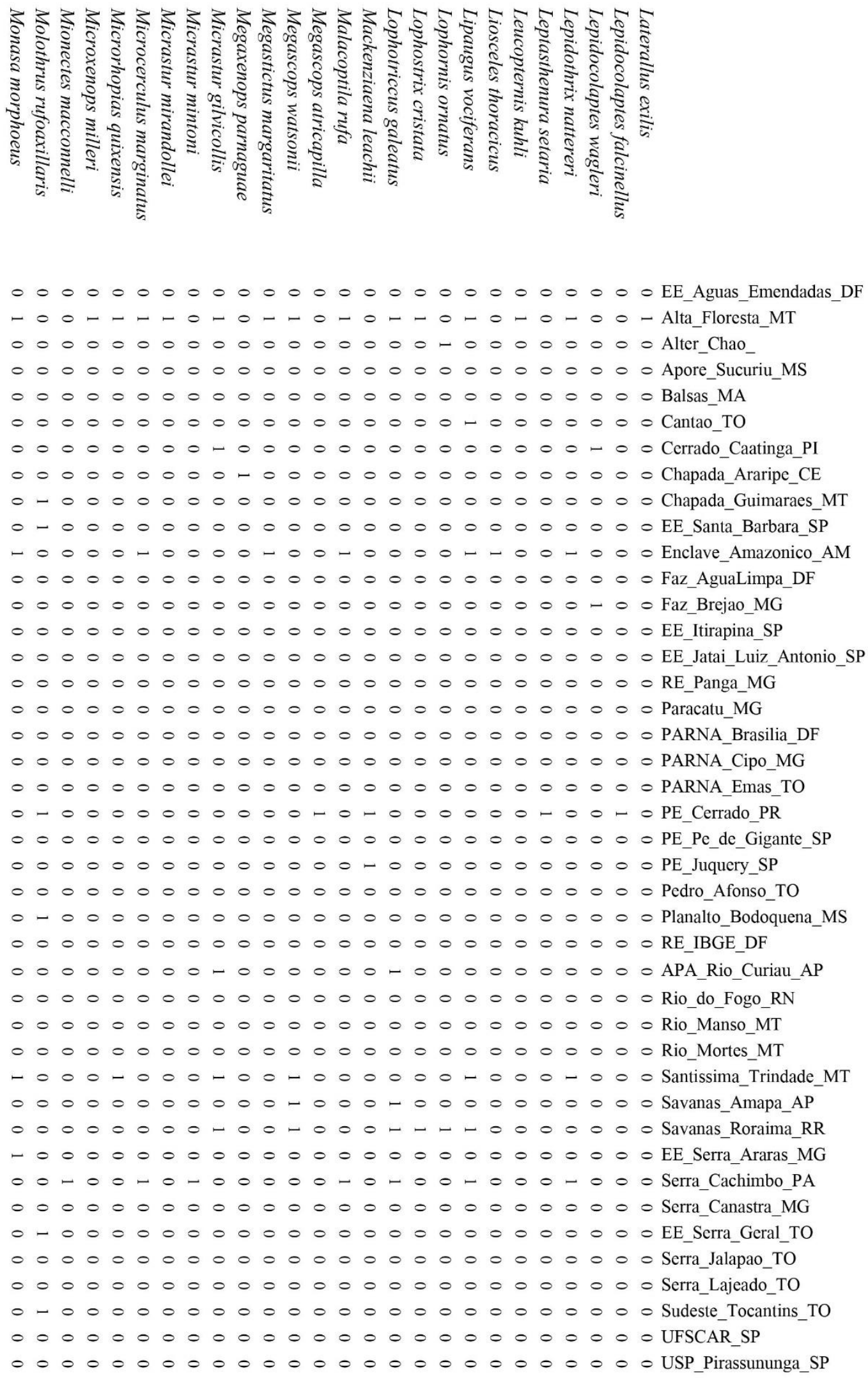

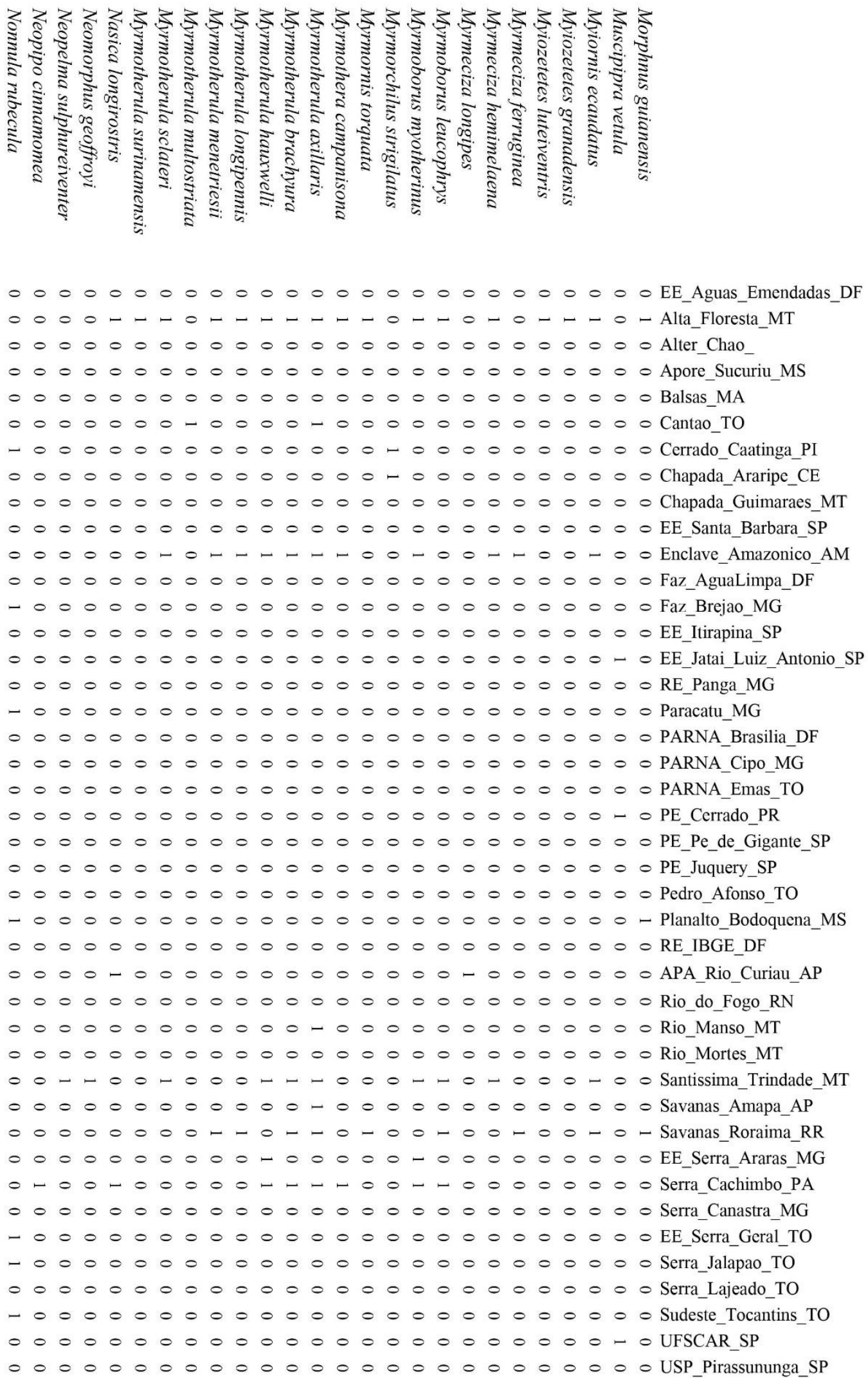

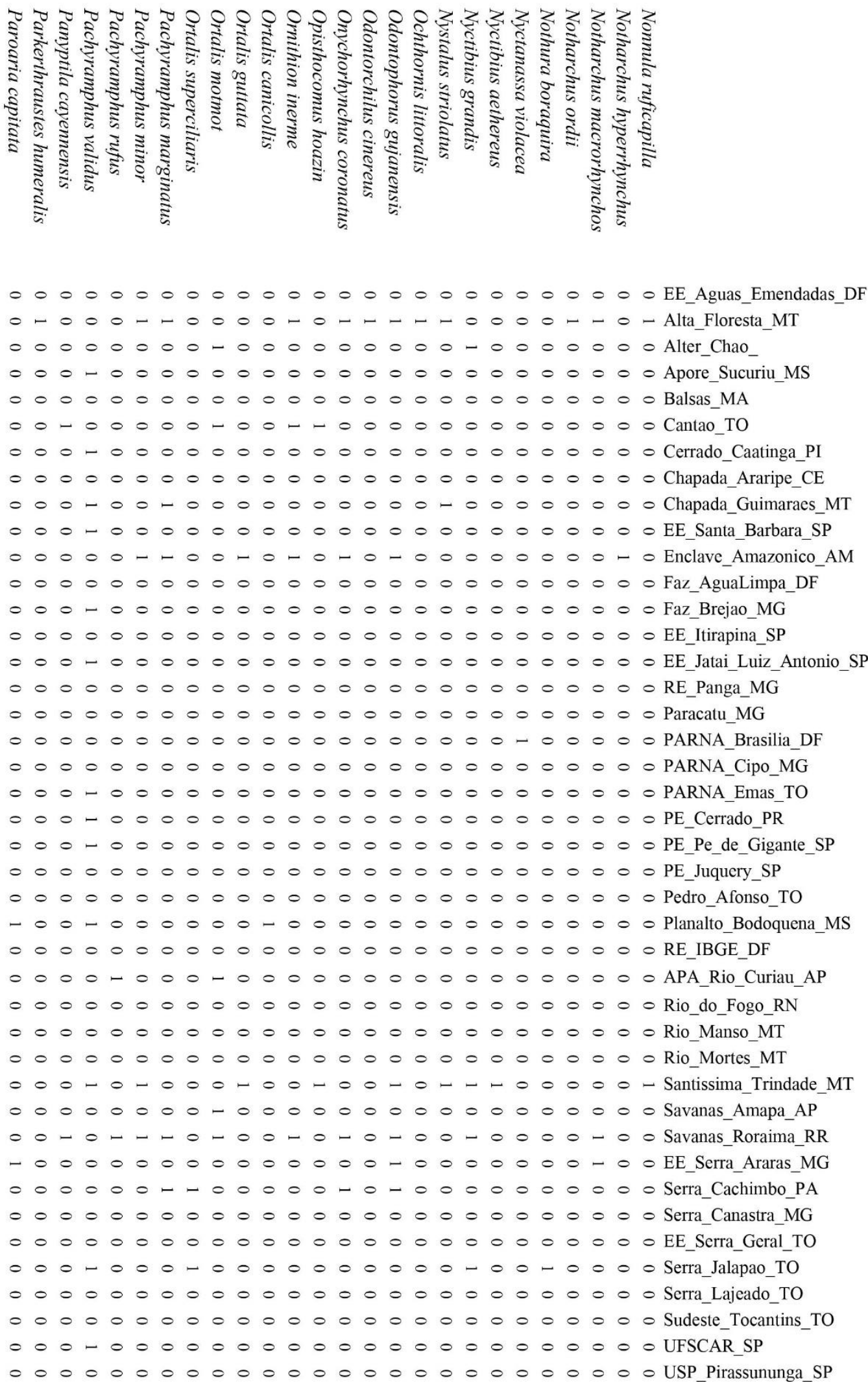

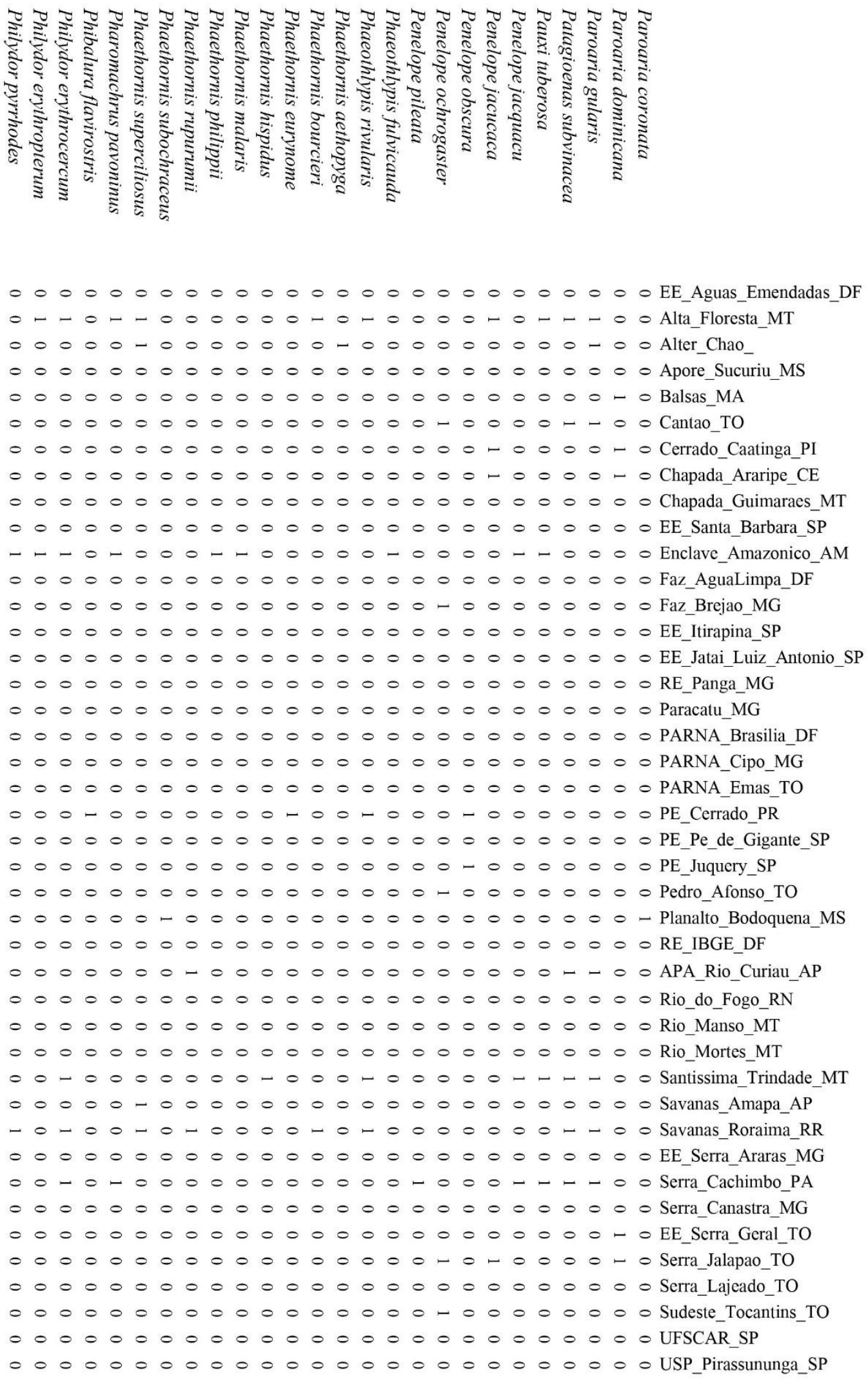

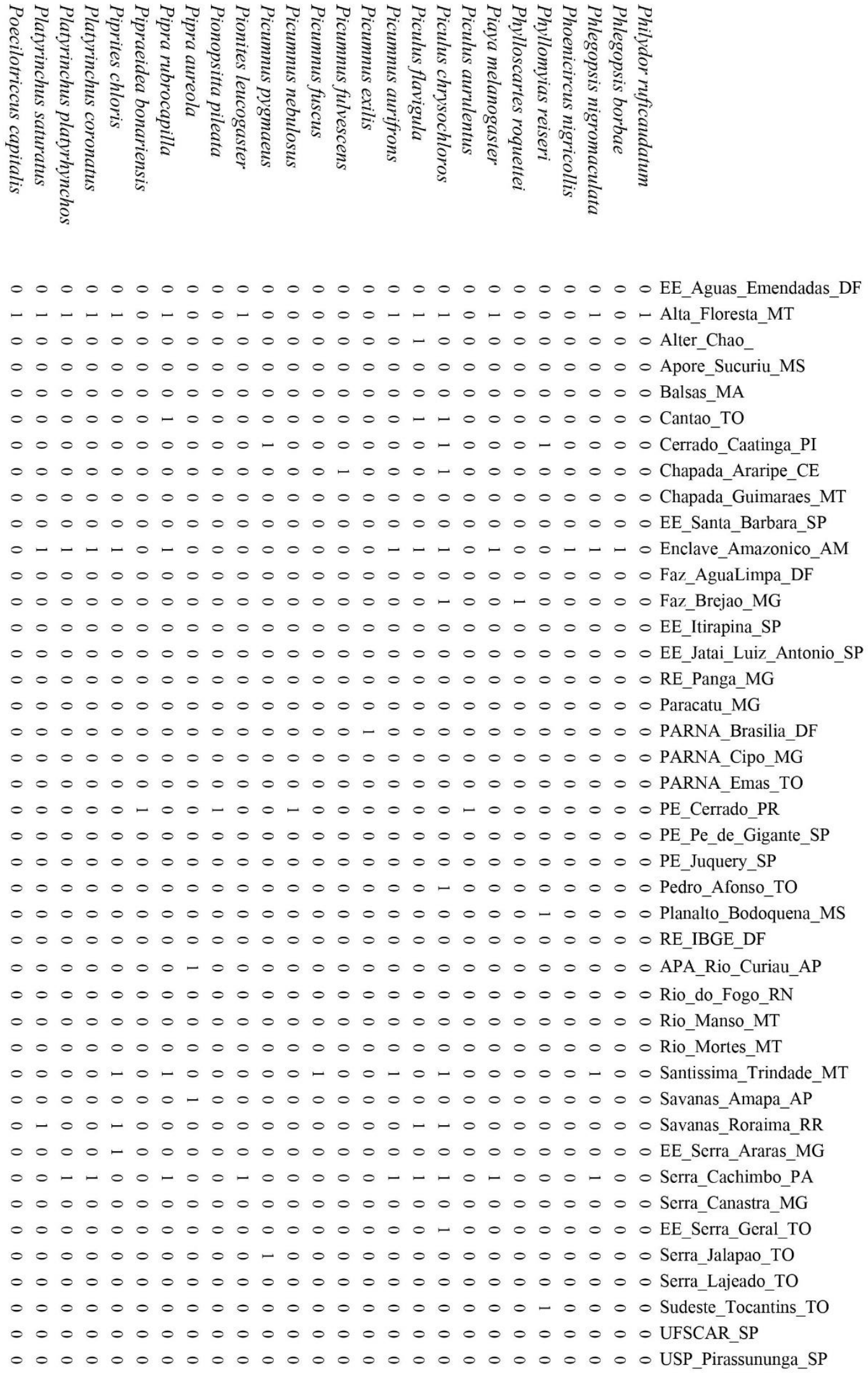


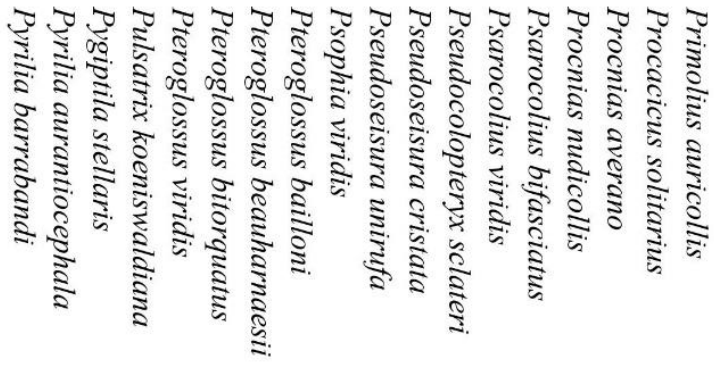

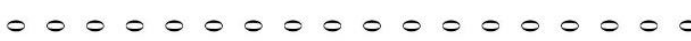
- $0-00-1-0-0000000-0$ - 0000000000000000

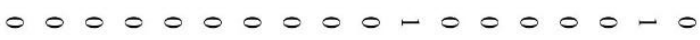
- $0000000000000-00$ - 000000000000000 - - $00000000-00000-0$

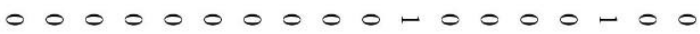
00000000000000000 - 0000000000000000 o o- 0 - $-1-0-0000$ - 0000 - 0000000000000000

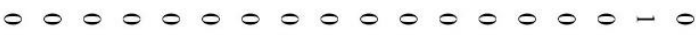
- o o o o o o o o o o o o l o - $000000000000-000$ - 0000000000000000 - 0000000000000000 - 0000000000000000 - 0000000000000000 - 0000000000000000

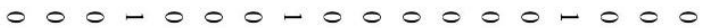
- 0000000000000000 - 0 o 0000000000000 - 0 o 00000000000000 - 0 0 $000000-0-0000-0$ 000000000000000000 - 0000000000000000 - $00000000000000-0$ - 000000000000000 - 0000000000000000

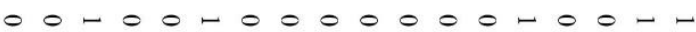
- o o o o o o o o o o o o o 00 - $000-0000000-00000$

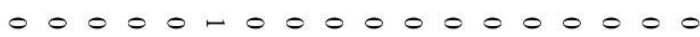

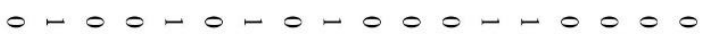
- 0000000000000000 - $0000000000000-00$ - $0000000000000-00$ - 0000000000000000 - 0000000000000000 - 0000000000000000 00000000000000000

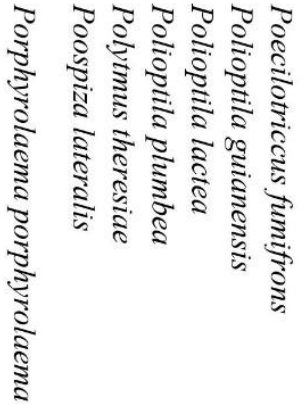

\footnotetext{
- 0000 EE_Aguas_Emendadas_DF - $\circ \circ$ - o Alta_Floresta_MT

- 0 o o Alter Chao

- 0 ○ 0 ○ Apore_Sucuriu_MS

- -0 o o Balsas_MA

- 0 o o o Cantao_TO

- -0 o C Cerrado_Caatinga_PI

- -0 - 0 Chapada_Araripe_CE

- 0 - 0 Chapada_Guimaraes_MT

- 0 - 0 o 0 EE_Santa_Barbara_SP

- -0 o 0 Enclave_Amazonico_AM

- 0 - 0 Faz_AguaLimpa_DF

- 0 o o Faz_Brejao_MG

- 0 - 0 o EE_Itirapina_SP

- 0 ○ 0 EE_Jatai_Luiz_Antonio_SP

- 0 ○ 0 o RE_Panga_MG

- 0 0 0 Paracatu_MG

- 000 O PARNA_Brasilia_DF

- $\circ \circ 0$ o PARNA_Cipo_MG

- 0 ○ 0 o PARNA_Emas_TO

- 0000 PE Cerrado PR

- 0000 PE_Pe_de_Gigante_SP

- 000 o PE_Juquery_SP

- 0 - 0 o Pedro_Afonso_TO

- 0 - o 0 Planalto_Bodoquena_MS

- 00 o 0 RE_IBGE_DF

- -0 - 0 APA_Rio_Curiau_AP

- -0 o 0 Rio_do_Fogo_RN

- 0 o 0 - Rio_Manso_MT

- 0 ○ o Rio_Mortes_MT

- 0 o o Santissima_Trindade_MT

- -0 - - - Savanas_Amapa_AP

- - - 0 o Savanas_Roraima_RR

- 0 - 0 EE_Serra_Araras_MG

- 0 - 0 Serra_Cachimbo_PA

- 0 - 0 o Serra_Canastra_MG

- 0 o o EE Serra Geral TO

- - - 0 - Serra_Jalapao_TO

- 0 o 0 o Serra_Lajeado_TO

- 0 - 0 Sudeste Tocantins TO

- 0 - 0 U UFSCAR SP

- 0000 USP Pirassununga SP
} 


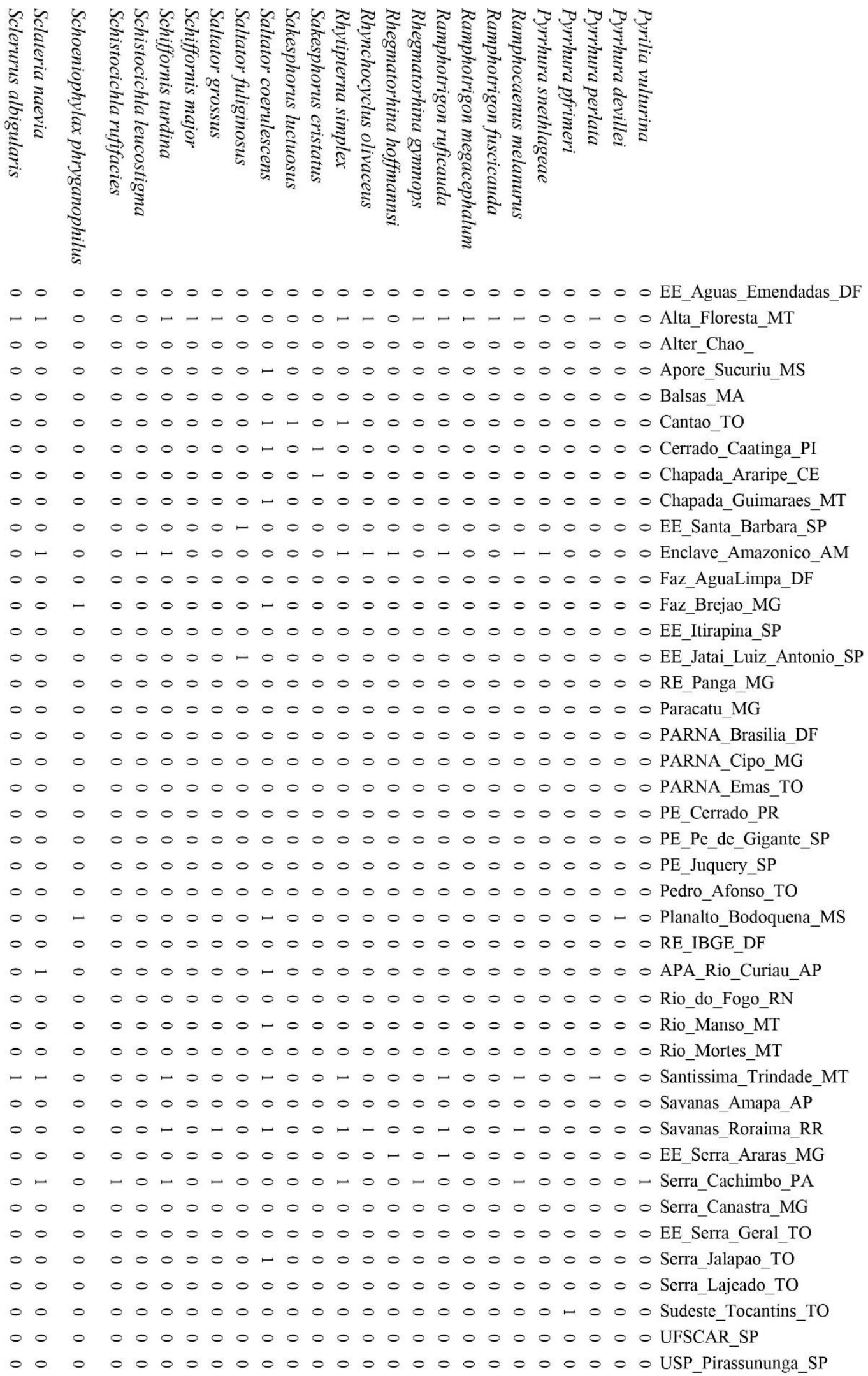



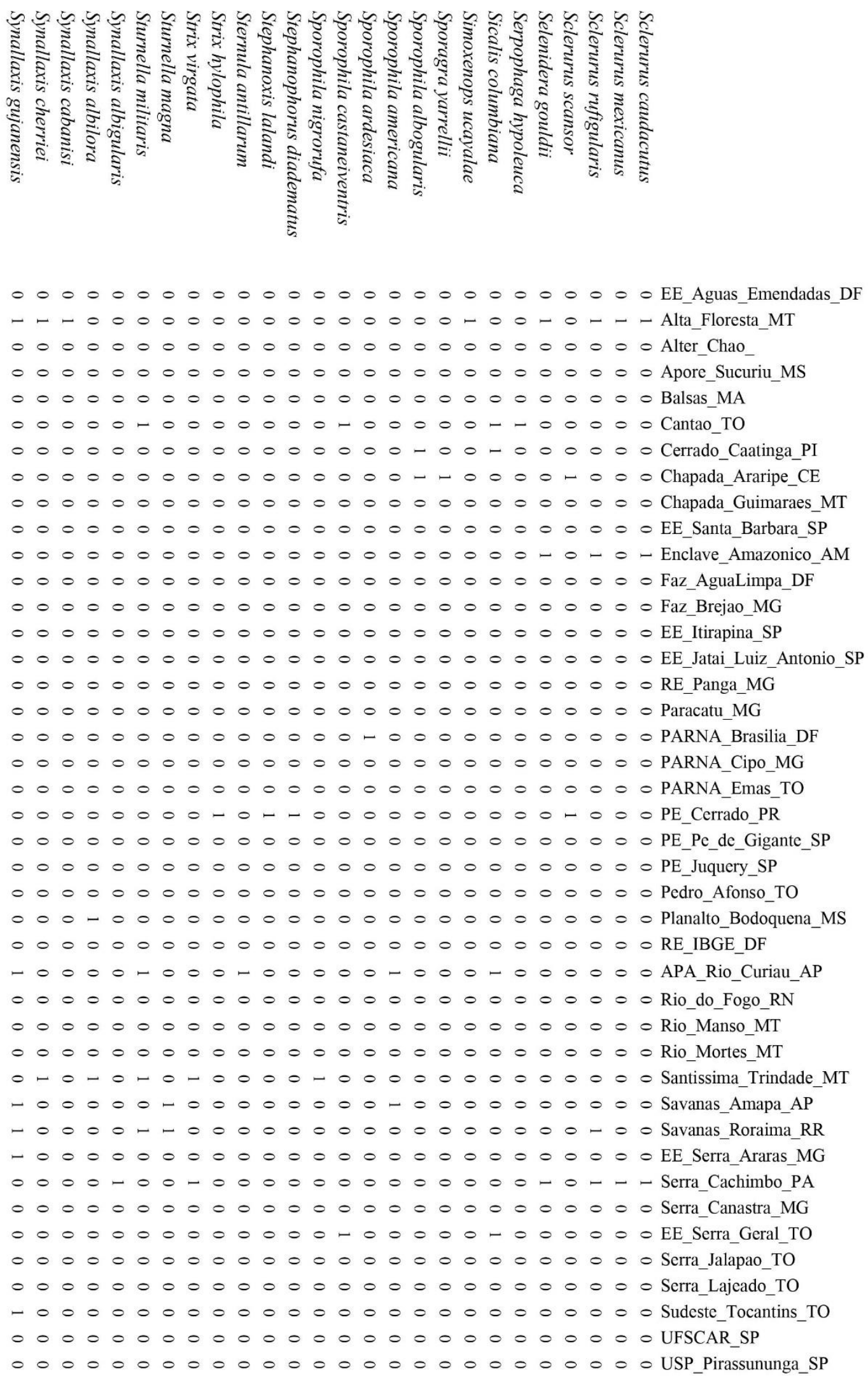

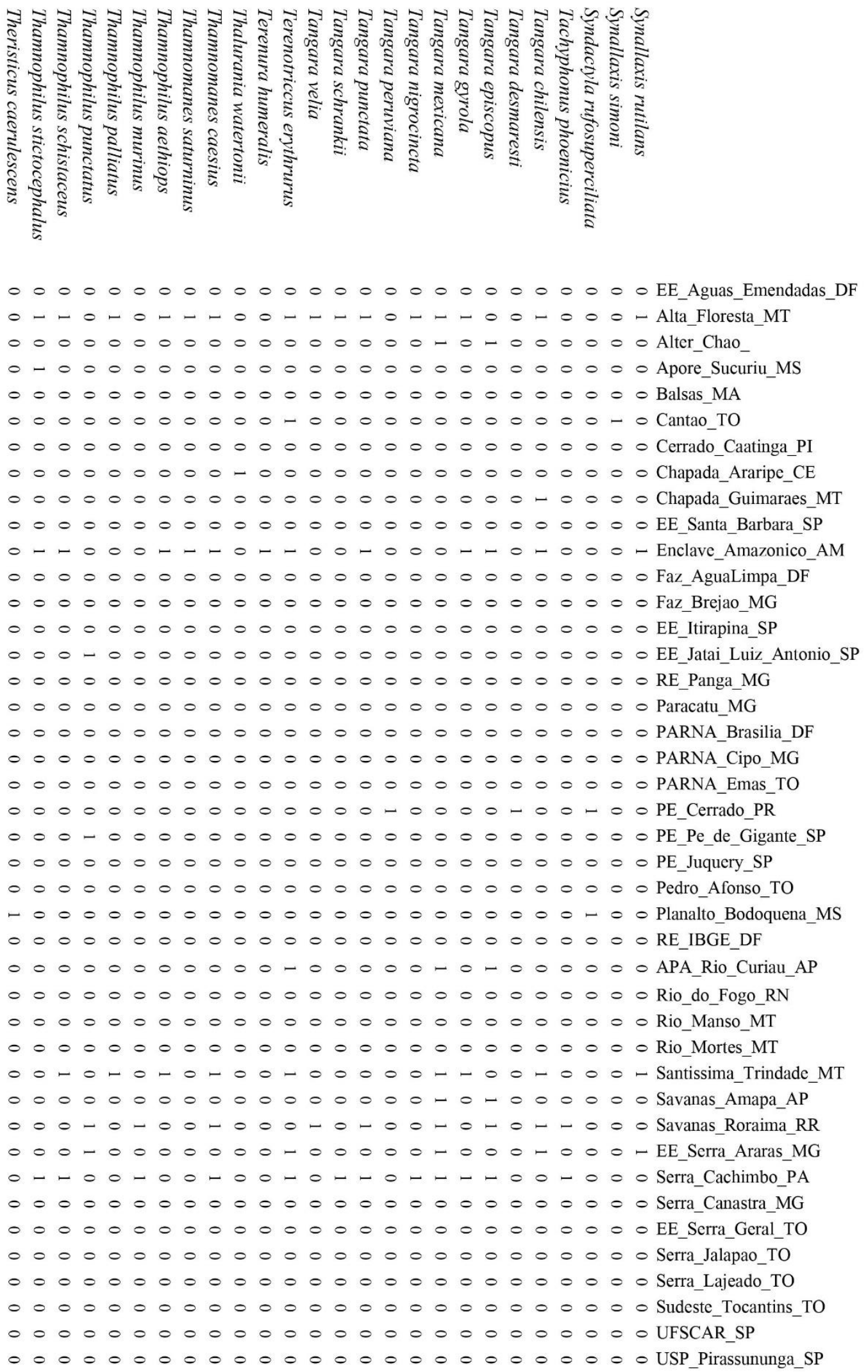

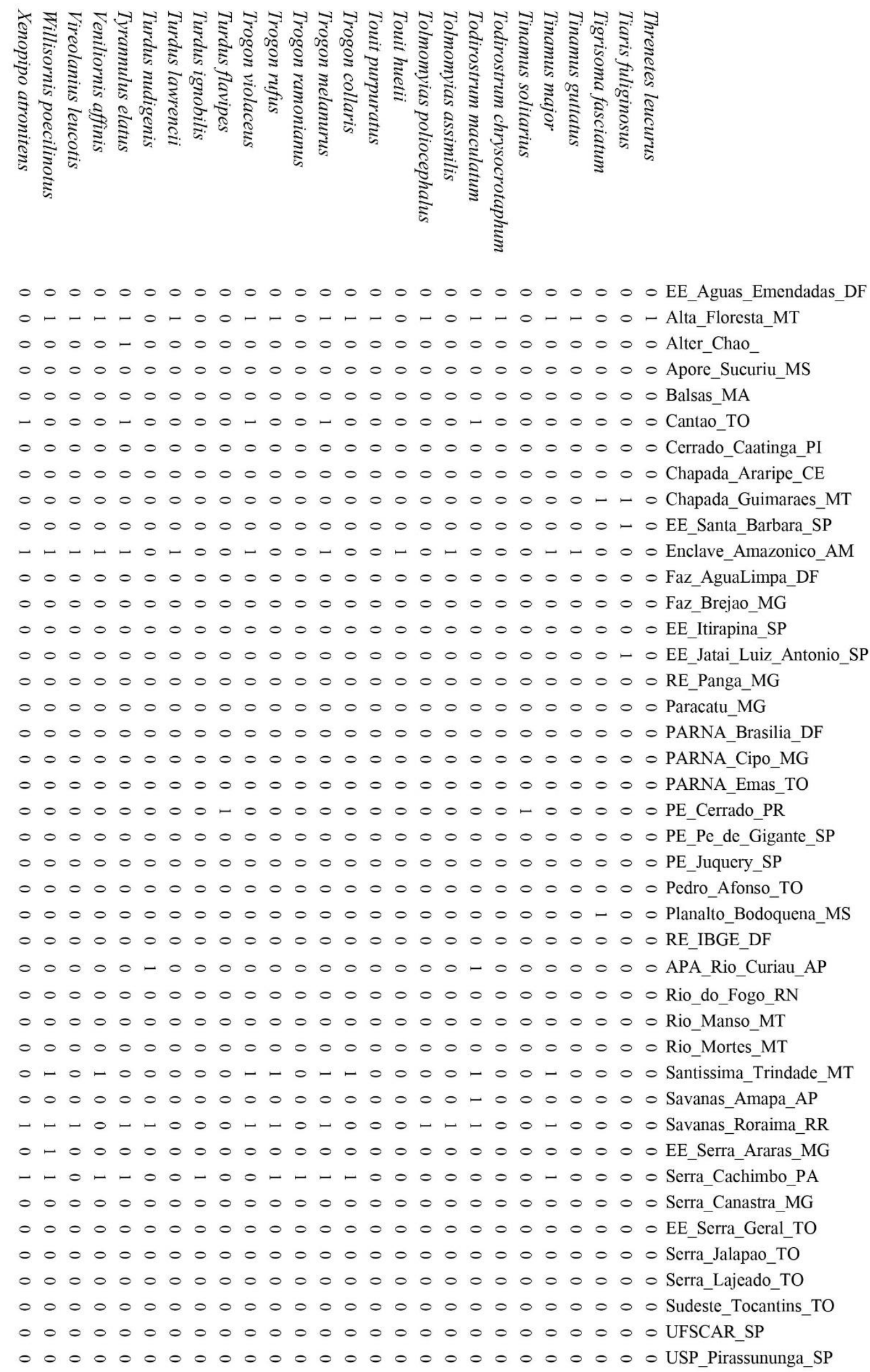


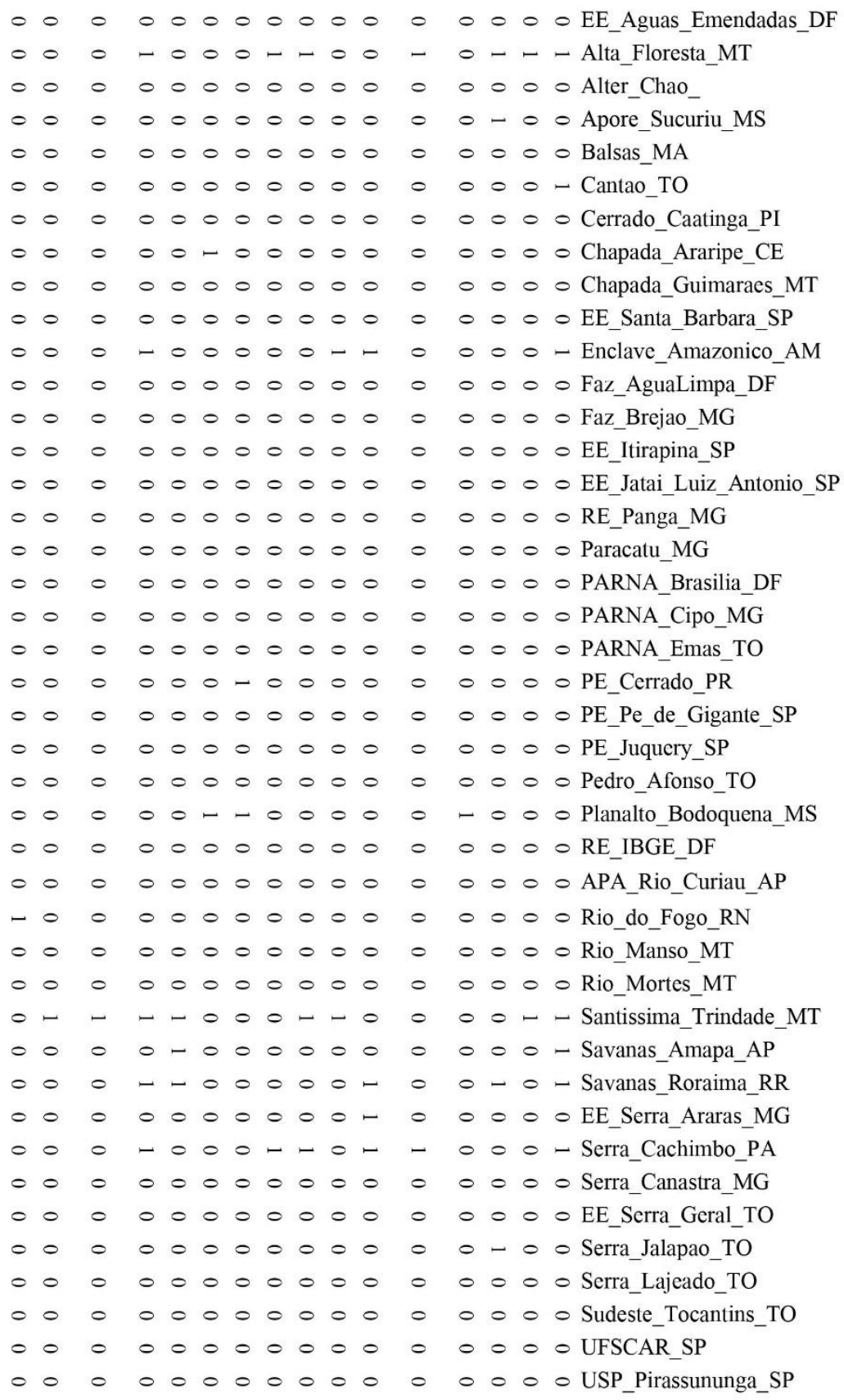


Table S4. Matrix with 42 sites and 95 bird species that composed the second network.
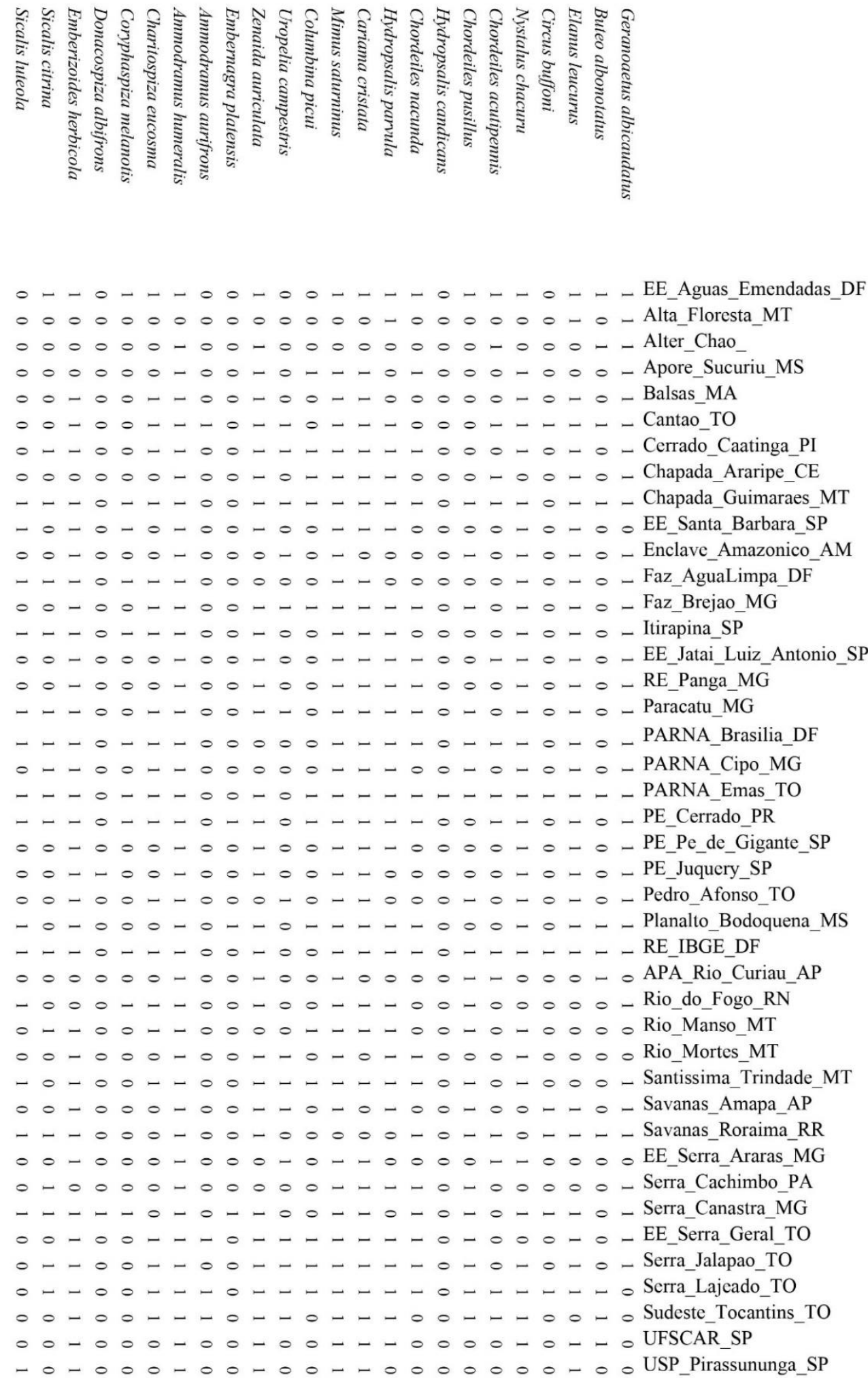

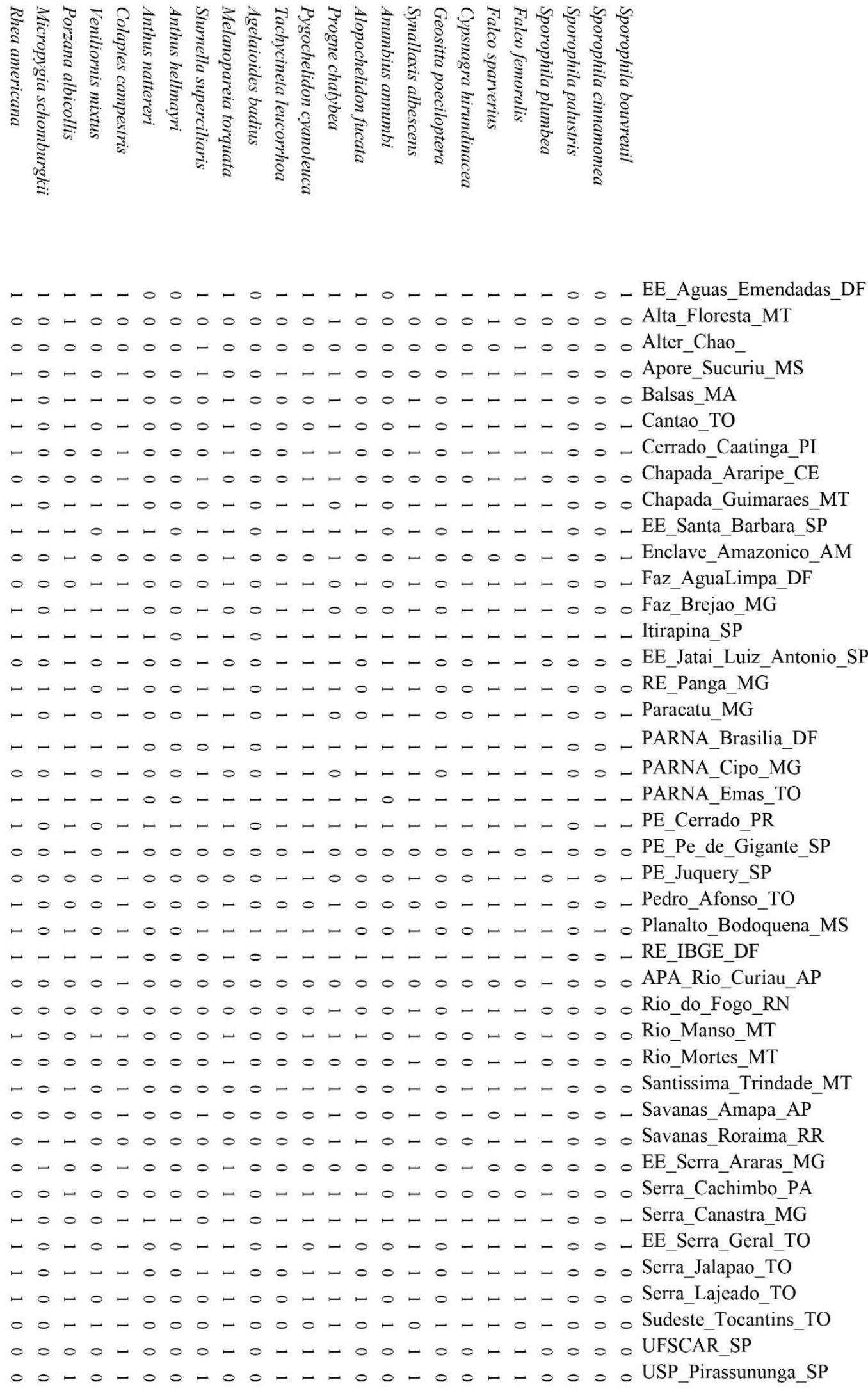

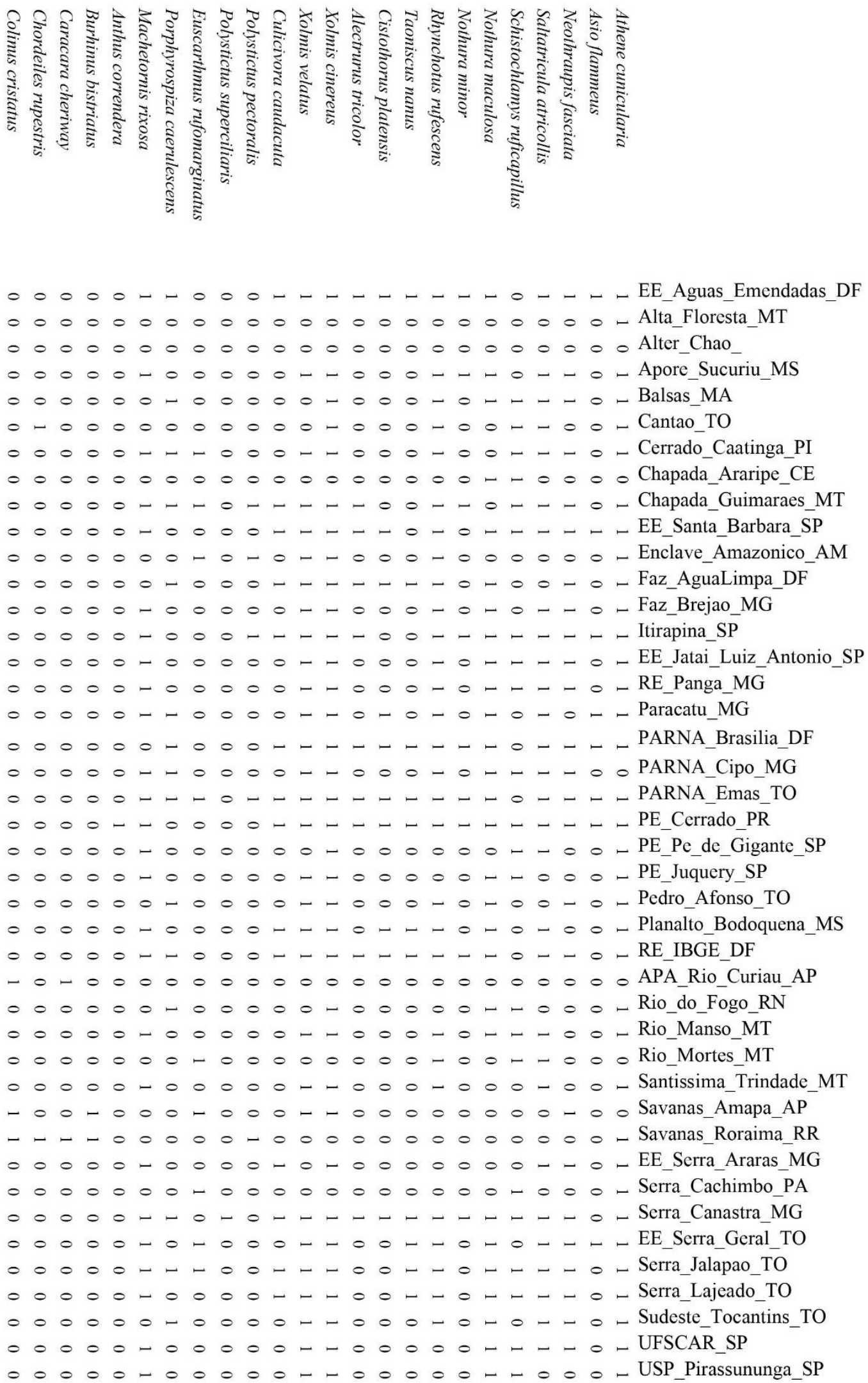

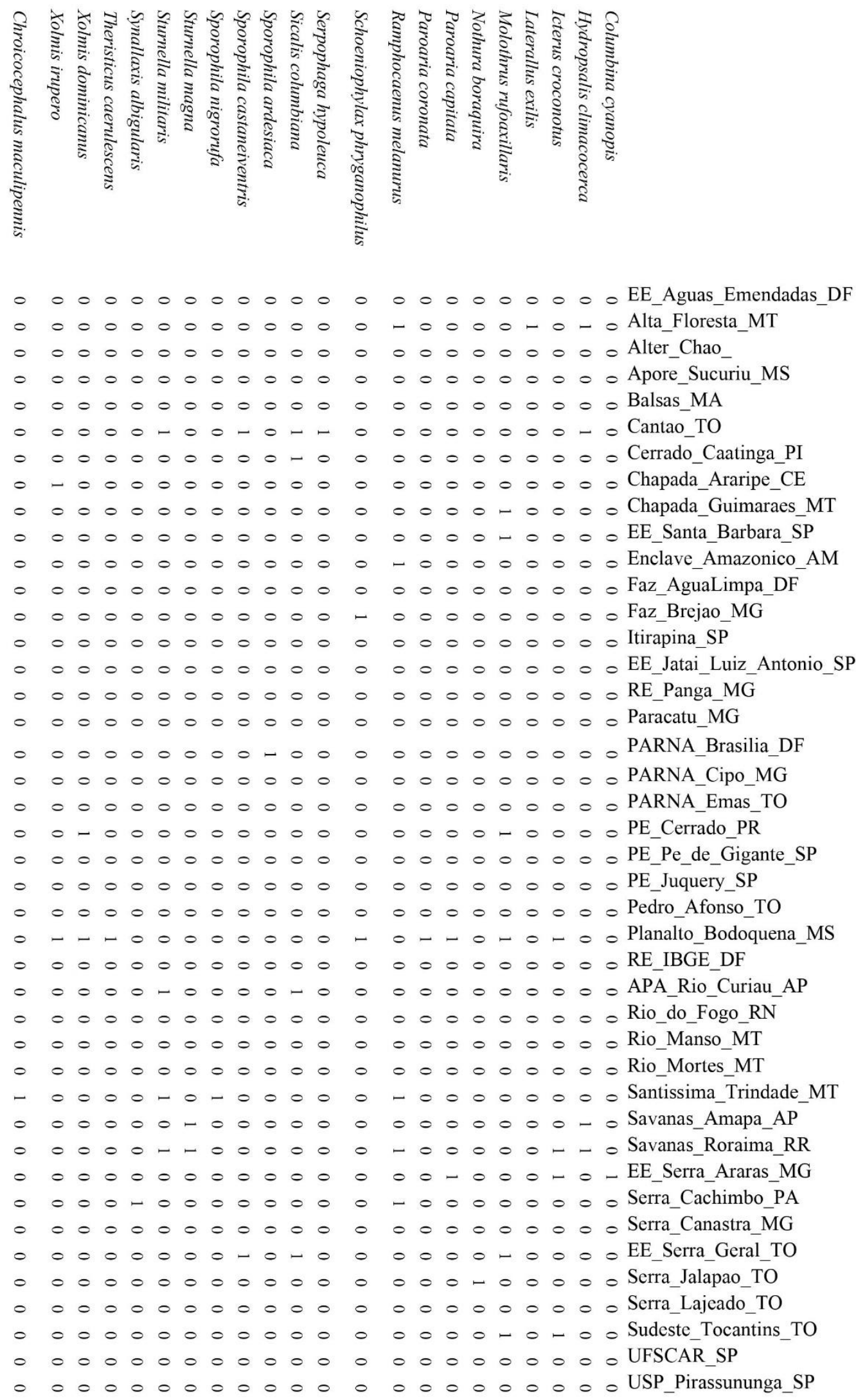
- EE_Aguas_Emendadas_DF

- Alta_Floresta_MT

- Alter_Chao

- Apore_Sucuriu_MS

- Balsas_MA

- Cantao_TO

- Cerrado_Caatinga_PI

- Chapada_Araripe_CE

- Chapada_Guimaraes_MT

- EE Santa_Barbara SP

- Enclave_Amazonico_AM

- Faz_AguaLimpa_DF

- Faz_Brejao_MG

- Itirapina_SP

- EE_Jatai_Luiz_Antonio_SP

- RE_Panga_MG

- Paracatu_MG

- PARNA_Brasilia_DF

- PARNA_Cipo_MG

- PARNA_Emas_TO

- PE_Cerrado_PR

- PE_Pe_de_Gigante_SP

- PE_Juquery_SP

- Pedro_Afonso_TO

- Planalto_Bodoquena_MS

- RE_IBGE_DF

- APA_Rio_Curiau_AP

- Rio_do_Fogo_RN

- Rio_Manso_MT

- Rio_Mortes_MT

- Santissima_Trindade_MT

- Savanas_Amapa_AP

- Savanas_Roraima_RR

- EE_Serra_Araras_MG

- Serra_Cachimbo_PA

- Serra_Canastra_MG

- EE_Serra_Geral_TO

- Serra_Jalapao_TO

- Serra_Lajeado_TO

- Sudeste_Tocantins_TO

- UFSCAR_SP

。 USP_Pirassununga_SP 


\section{MATERIAL SUPLEMENTAR - CAPÍTULO 2}

Tabela S1: Matriz de traços funcionais por espécie, elaborada a partir de Morandini (2013).

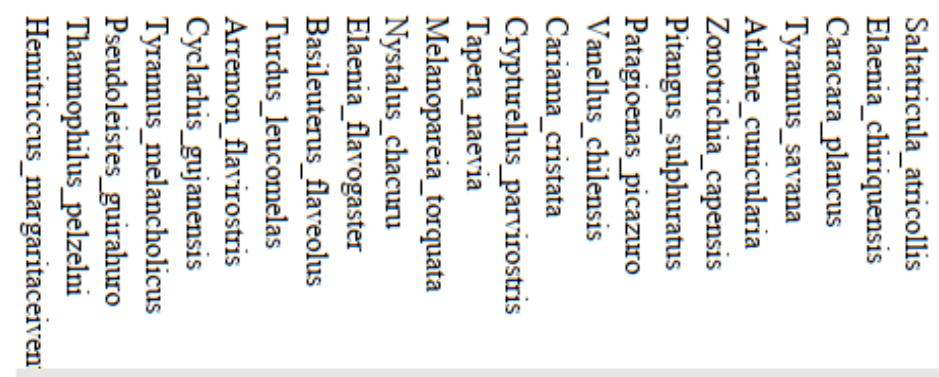

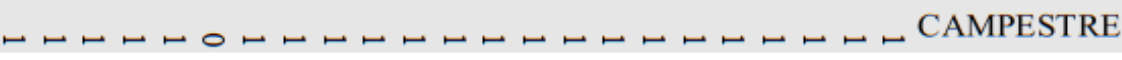

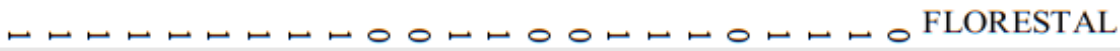

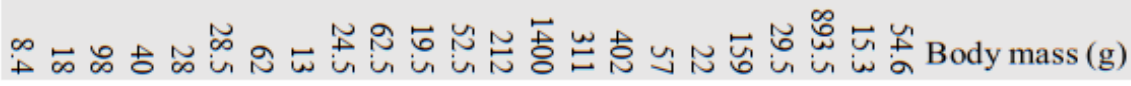

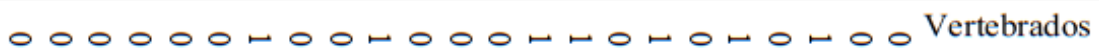

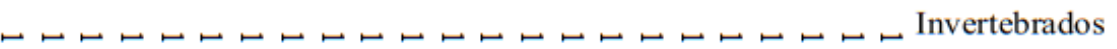

00000000000000010000000 Folha-parte verde

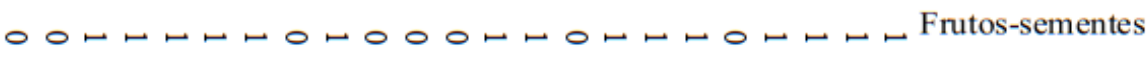

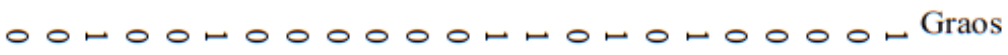

00000000000000000000000 Flores

$00000000000000000000000^{\text {Nectar }}$

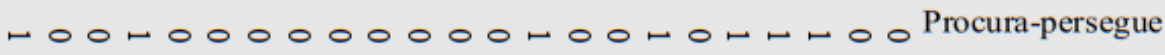

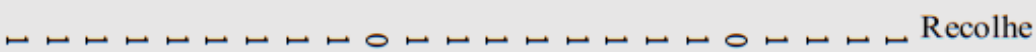

เ

00000000000000000000000 Bica

$00000000000000010000000^{\text {Pasta }}$

00000000000000000000000 Vasculha-cava

$00010000000000101000000^{\text {Agua }}$

$00000000000000-00000000$ Solo umido-encharcado

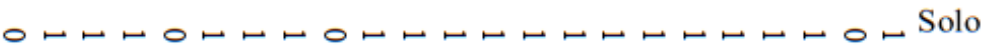

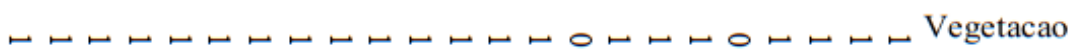

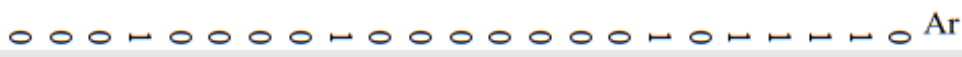

$0000000000000000-000000^{\text {Cavidade-fenda-oco }}$

$00-00000000000000000000^{T}$ Topo-extremidade

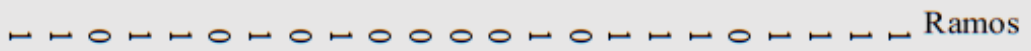

- 0 - 0 - 000000000000000000 Suspenso

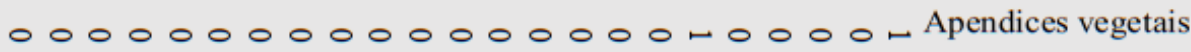

00000000000000000000000 Vegetacao palustre

$00000000000000000010000^{\text {Cupim-vespa-formigueiro }}$

0000000001000000 - 000000 Paredao-barranco

000000000000000000 - $00^{\text {ninhos desocupados }}$

$00000000000-00000000000^{N i n h o ~ a t i v o ~ o u t r a ~ e s p e ́ c i e ~}$

$00000000000000000000000^{\text {Na-proximo da agua }}$

0 0 0 0 0 -

$000000-000000000-100000^{\text {Edificacoes humanas }}$ 


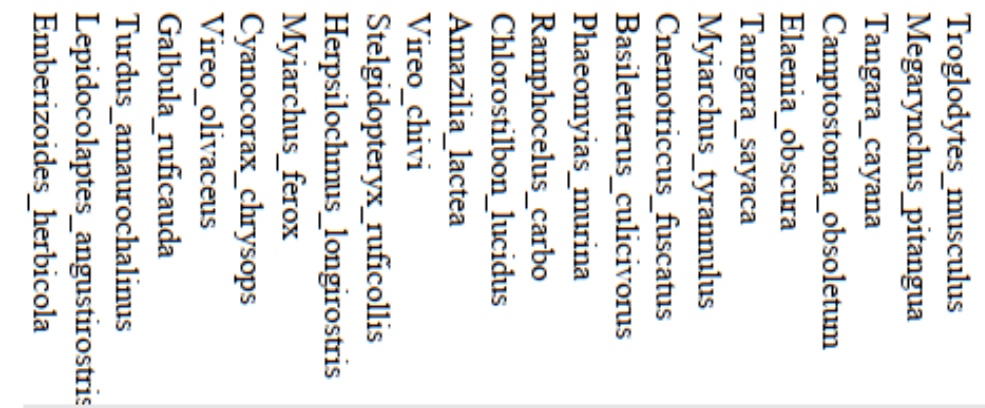

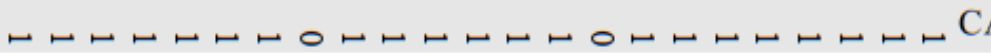

CAMPESTRE

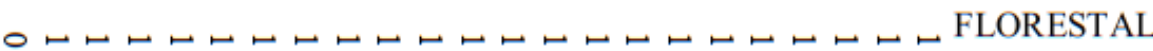

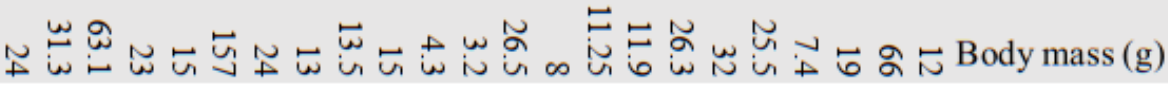

० 0000000000000000000 - Vertebrados

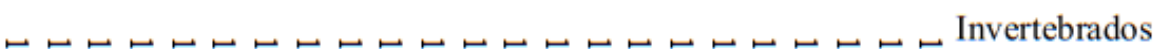

$00000000000000000-00000$ Folha-parte verde

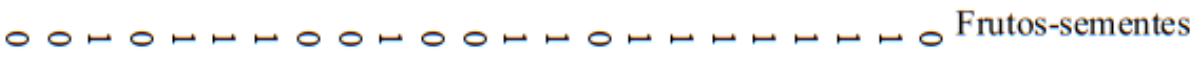

- $0000000000010000000000^{\mathrm{Gra}}$

00000000000000000100000 Flores

0 000000000-1-0000100000 Nectar

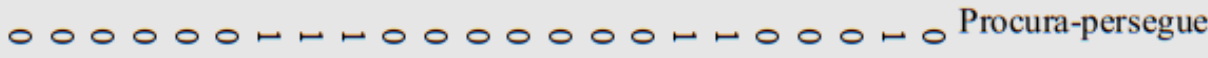

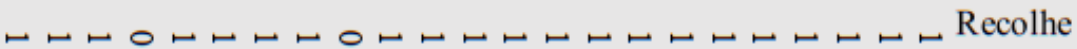

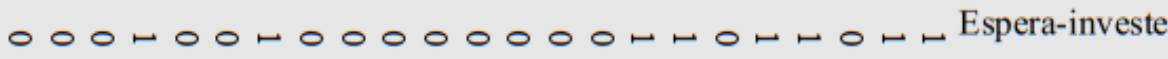

or 000000000000000000000 Bica

$00000000000000000100000^{\text {Pasta }}$

or 00000000 - 0000000000 Vasculha-cava

00000000000000000000000 Agua

00000000000000000000000 Solo umido-encharcado

roro0ror0000000rr00000r Solo

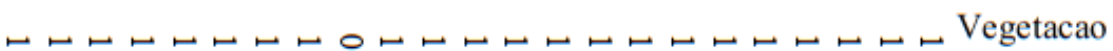

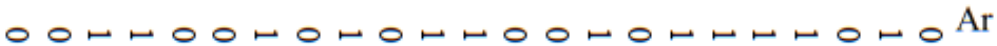

00000-000000000-00000- Cavidade-fenda-oco

$00000000000000000000000^{\text {Topo-extremidade }}$

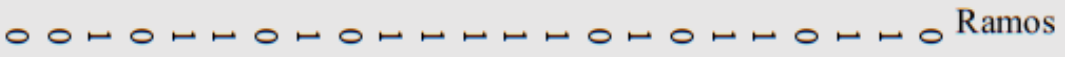

0 0001000010000000000000 Suspenso

00000000000000000001000 Apendices vegetais

00000000000000000000000 Vegetacao palustre

$000-0000000000000000000$ Cupim-vespa-formigueiro

$000-0000100000000000000$ Paredao-barranco

$0-00000000000000000000-n^{n}$ inhos desocupados

00000000000000000000000 Ninho ativo outra espécie

$00000000100000000000000^{\text {Na-proximo da agua }}$

- $0000000000000-00000000$ Solo

$0000000000000000000000{ }^{-}$Edificacoes humanas 


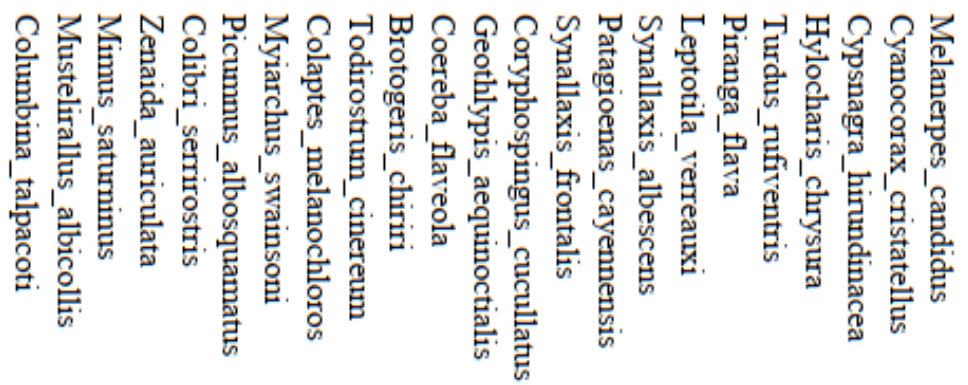

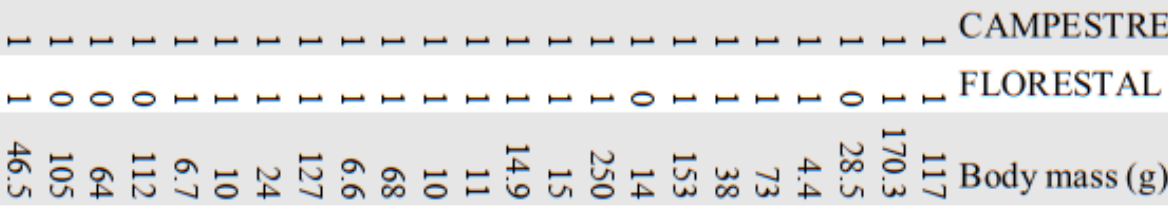

०० 00000000000000000000 Vertebrados

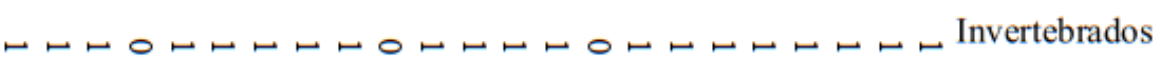

$0-000000000000000000000$ Folha-parte verde

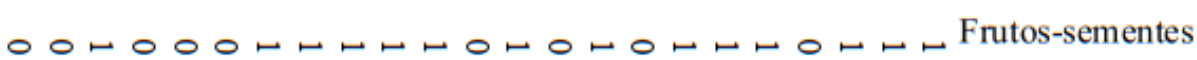

r-0 -

00100000010000000000000 Flores

o0ror0000r-000000001000 Nectar

$00000010-00000000000000$ Procura-persegue

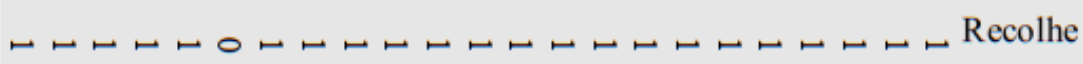

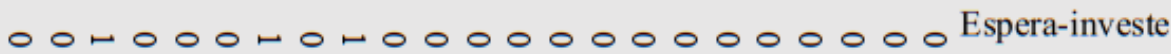

0000r0-00000000000000-Bica

0 - $000000000000000000000^{P a s t a}$

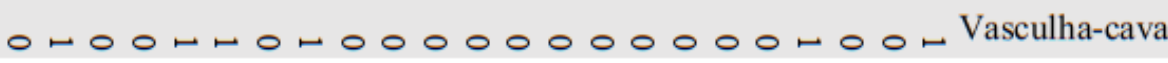

00000000000000000000000 Agua

0 - 00000000000000000000 Solo umido-encharcado

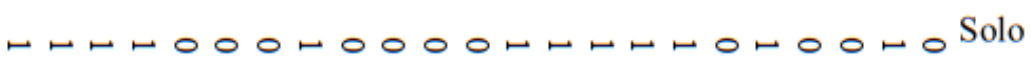

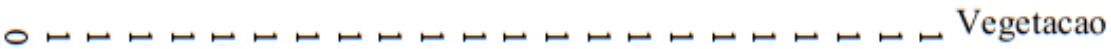

0000r0r0000000000r0r00r Ar

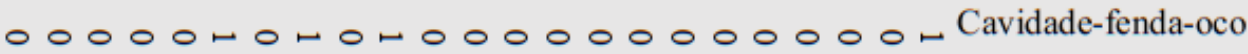

$00000000000000000000000^{\text {Topo-extremidade }}$

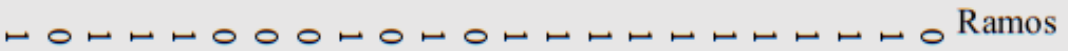

00000000100000000000000 Suspenso

00000000001000000000000 Apendices vegetais

0 - 00000000000000000000 Vegetacao palustre

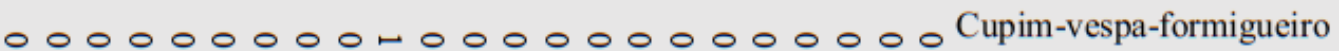

00000000000000000000000 Paredao-barranco

- ○-000-00-000000000000 ninhos desocupados

00000000000000000000000 Ninho ativo outra espécie

$0-000000000000000000000$ Na-proximo da agua

oror

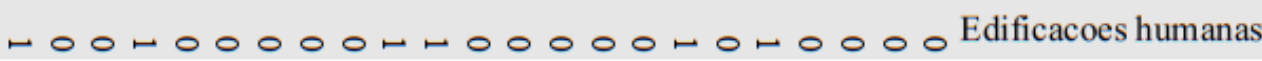




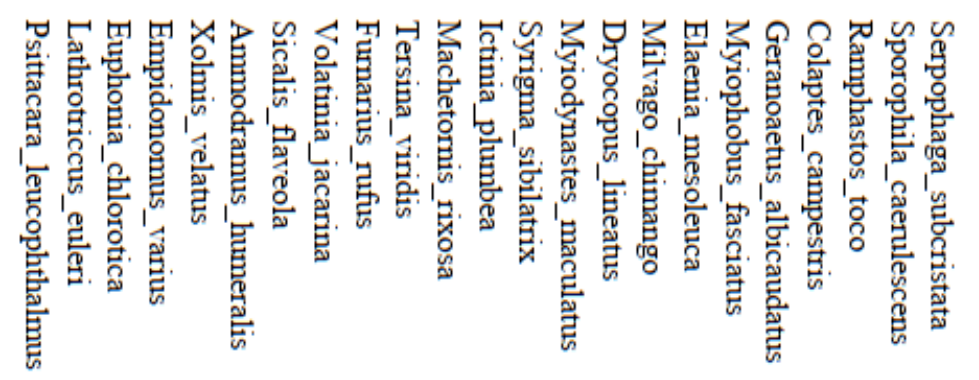

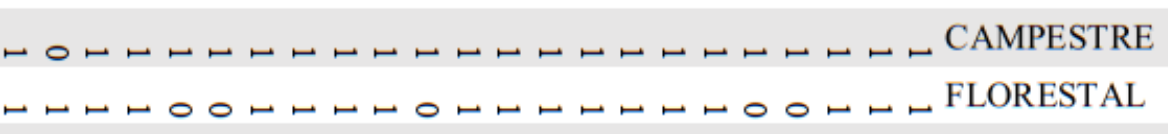

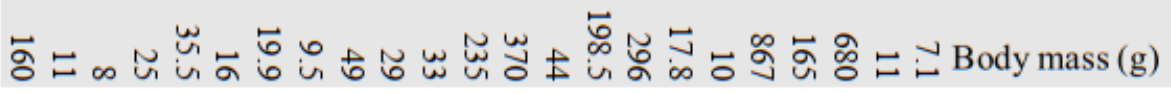

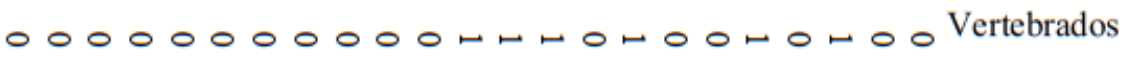

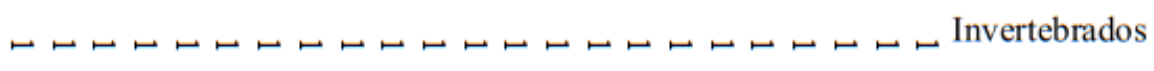

00000000000000000000000 Folha-parte verde

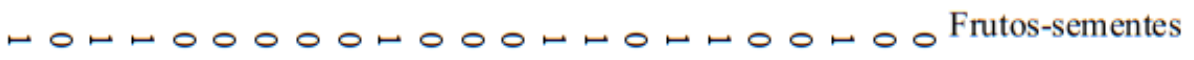

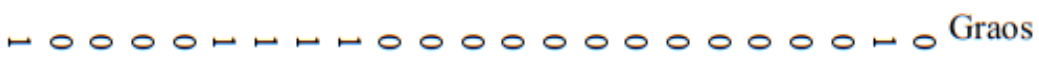

- 0000000 0000000000000 Flores

0 0 0 000000000000000000 Nectar

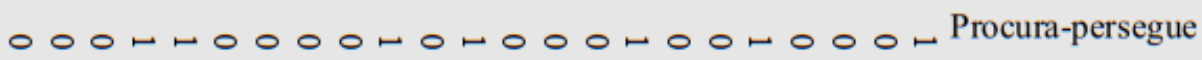

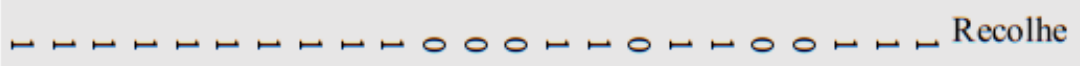

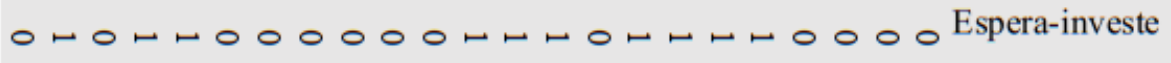

000000000000010000-000 Bica

$00000000001000000000000 \mathrm{Pasta}$

000000000000010000-100 Vasculha-cava

0000000000010000000000Agua

○ $00000000-0000000000$ Solo umido-encharcado

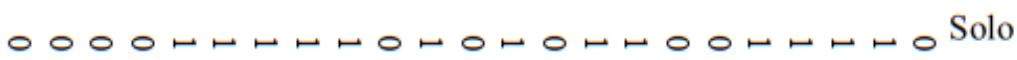

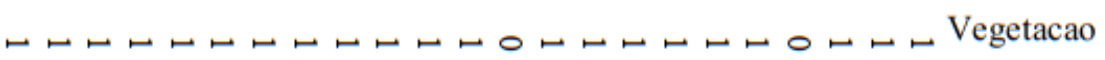

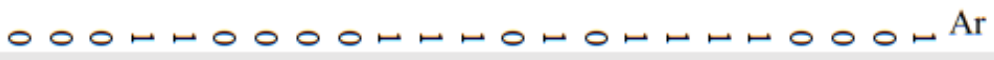

•

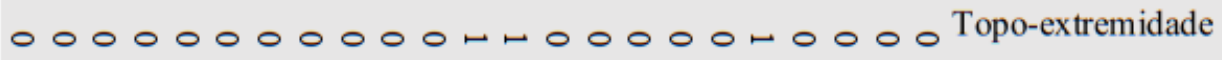

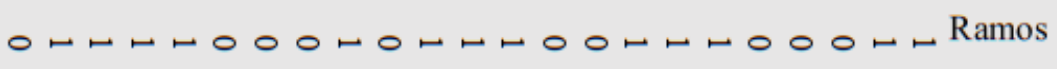

00000000000000000000000 Suspenso

$000000 \div 000000000000000$ Apendices vegetais

00000000000000000000000 Vegetacao palustre

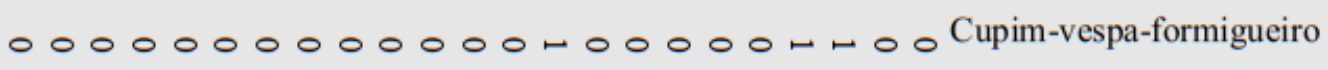

•

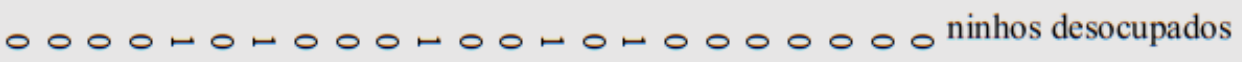

0000000000000000000000 Ninho ativo outra espécie

0000000000100000000000 Na-proximo da agua

0000100000000010000000 Solo

- 0000 0000000000000000 Edificacoes humanas 


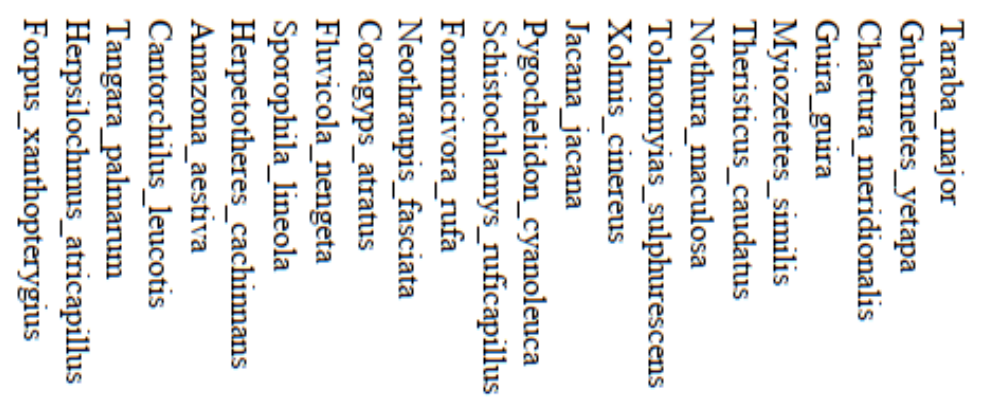

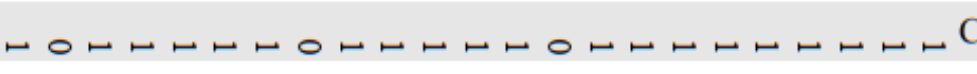

CAMPESTRE

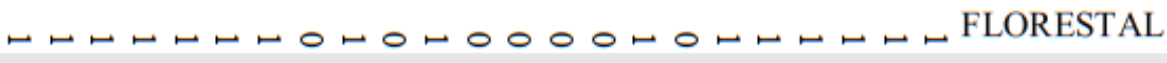

స 눈

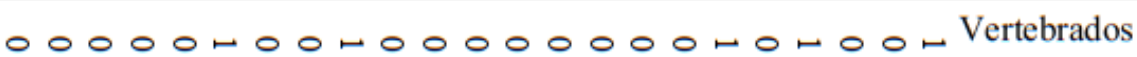

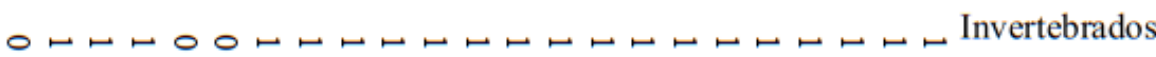

००-00000000000001000000Folha-parte verde

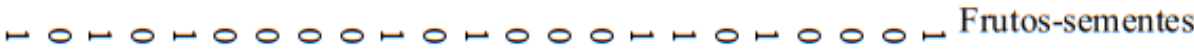

ro00r0r000000r00r000000 Graos

- 000 - 00000000000000000 Flores

$00001000000001000000000^{N e c t a r}$

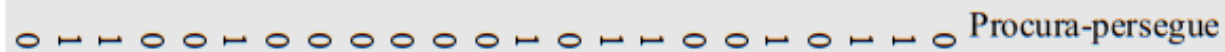

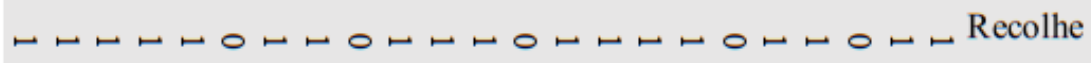

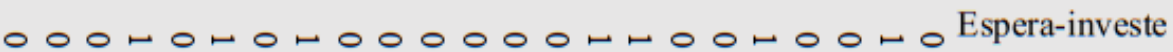

$00000000000000000000000^{B i c a}$

0 0r $00000000000001000000^{P a s t a}$

$0000000000-00000$ - 0000 Vasculha-cava

0000000100000 - 000 - 0000 Agua

00000000100000000 - 00000 Solo umido-encharcado

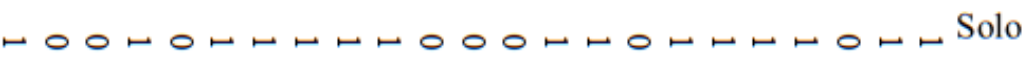

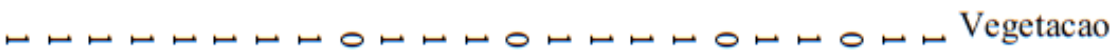

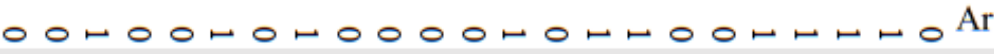

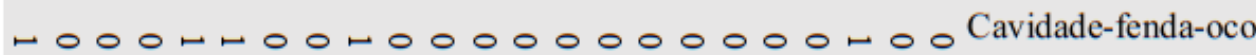

$00000000000000000000000^{\text {Topo-extremidade }}$

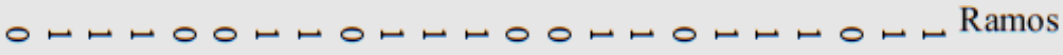

00000000000000010000000 Suspenso

$00-00000000-00000000000$ Apendices vegetais

00000000000001000000000 Vegetacao palustre

- $0000000000000000000000^{\text {Cupim-vespa-formigueiro }}$

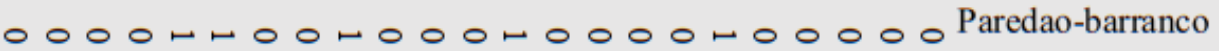

- 0000 000000r0000000000 ninhos desocupados

00000000000000000000000 Ninho ativo outra espécie

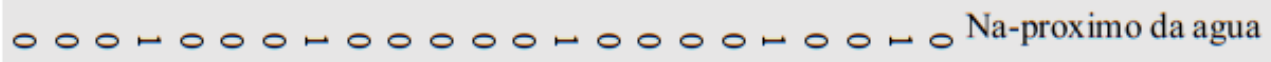

0000000010000r00 r000000 Solo

000000001000 0 


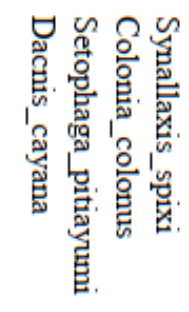

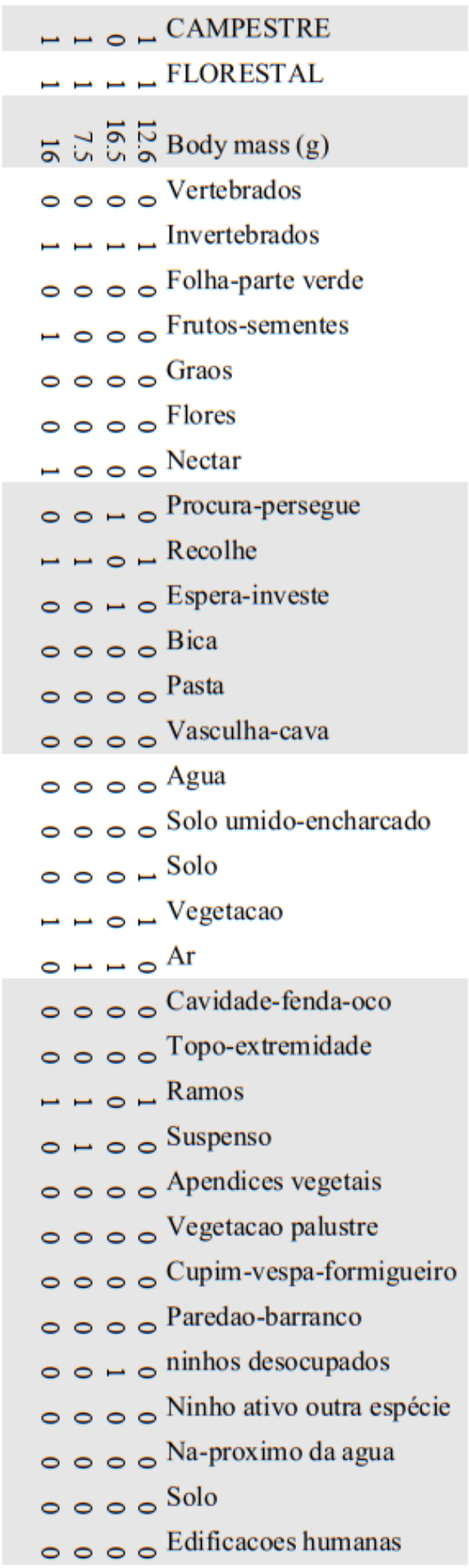


Tabela S2: Lista das espécies registradas nos pontos de escuta e observação por ambiente. O valor numérico indica o número de pontos em que a espécie foi registrada em cada ambiente.

\begin{tabular}{|c|c|c|c|c|c|}
\hline Família & Espécie & 递 & 赵 & 劳 & 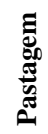 \\
\hline Accipitriformes/Accipitridae & Geranoaetus_albicaudatus & 1 & 0 & 0 & 0 \\
\hline Accipitriformes/Accipitridae & Ictinia_plumbea & 0 & 0 & 0 & 1 \\
\hline Apodiformes/Apodidae & Chaetura_meridionalis & 1 & 0 & 0 & 0 \\
\hline Apodiformes/Trochilidae & Amazilia_lactea & 0 & 2 & 0 & 0 \\
\hline Apodiformes/Trochilidae & Chlorostilbon_lucidus & 0 & 1 & 0 & 0 \\
\hline Apodiformes/Trochilidae & Colibri_serrirostris & 3 & 2 & 1 & 3 \\
\hline Apodiformes/Trochilidae & Hylocharis_chrysura & 3 & 6 & 0 & 0 \\
\hline asseriformes/Tyrannidae & Xolmies_cinereus & 0 & 0 & 0 & 1 \\
\hline asseriformes/Tyrannidae & Xolmis_velatus & 1 & 0 & 0 & 1 \\
\hline Cariamiformes/Cariamidae & Cariama_cristata & 4 & 2 & 2 & 1 \\
\hline Cathartiformes/Cathartidae & Coragyps_atratus & 1 & 0 & 0 & 2 \\
\hline Charadriiformes/Charadriidae & Vanellus_chilensis & 0 & 0 & 0 & 13 \\
\hline Charadriiformes/Jacanidae & Jacana_jacana & 0 & 0 & 0 & 1 \\
\hline Columbiformes/Columbidae & Columbina_talpacoti & 2 & 0 & 0 & 4 \\
\hline Columbiformes/Columbidae & Leptotila_verreauxi & 0 & 6 & 2 & 1 \\
\hline Columbiformes/Columbidae & Patagioenas_cayennensis & 0 & 1 & 0 & 0 \\
\hline Columbiformes/Columbidae & Patagioenas_picazuro & 10 & 20 & 15 & 12 \\
\hline Columbiformes/Columbidae & Zenaida_auriculata & 9 & 0 & 0 & 0 \\
\hline Cuculiformes/Cuculidae & Guira_guira & 0 & 0 & 0 & 6 \\
\hline Cuculiformes/Cuculidae & Tapera_naevia & 3 & 4 & 0 & 0 \\
\hline Falconiformes/Falconidae & Caracara_plancus & 0 & 0 & 0 & 2 \\
\hline Falconiformes/Falconidae & Herpetoteres_cachinnans & 0 & 0 & 0 & 1 \\
\hline Galbuliformes/Bucconidae & Nystalus_chacuru & 5 & 2 & 0 & 0 \\
\hline Galbuliformes/Galbulidae & Galbula_ruficauda & 0 & 1 & 0 & 0 \\
\hline Gruiformes/Rallidae & Mustelirallus_albicollis & 2 & 0 & 0 & 0 \\
\hline Passeriformes/Cardinalidae & Piranga_flava & 0 & 1 & 0 & 0 \\
\hline Passeriformes/Corvidae & Cyanocorax_chrysops & 5 & 5 & 1 & 3 \\
\hline Passeriformes/Corvidae & Cyanocorax_cristatelus & 3 & 2 & 3 & 2 \\
\hline Passeriformes/Dendrocolaptidae & Lepidocolastes_angustirostris & 2 & 1 & 0 & 4 \\
\hline Passeriformes/Fringillidae & Euphonia_chlorotica & 1 & 0 & 0 & 1 \\
\hline Passeriformes/Furnariidae & Furnarius_rufus & 0 & 0 & 2 & 10 \\
\hline Passeriformes/Furnariidae & Synallaxis_albescens & 5 & 2 & 0 & 0 \\
\hline Passeriformes/Furnariidae & Synallaxis_spixi & 0 & 0 & 0 & 1 \\
\hline Passeriformes/Furnariidae & Synallaxys_frontalis & 0 & 3 & 0 & 0 \\
\hline Passeriformes/Hirundinidae & Pygochelidon_cyanoleuca & 0 & 0 & 0 & 6 \\
\hline Passeriformes/Hirundinidae & Stelgidopteryx_ruficolis & 0 & 1 & 0 & 2 \\
\hline Passeriformes/Icteridae & Pseudoleistes_guirahuro & 3 & 1 & 0 & 1 \\
\hline Passeriformes/Melanopareiidae & Melanopareia_torquata & 3 & 0 & 0 & 0 \\
\hline Passeriformes/Mimidae & Mimus_saturninus & 5 & 0 & 0 & 6 \\
\hline Passeriformes/Parulidae & Basileuterus_culicivorus & 0 & 3 & 1 & 0 \\
\hline
\end{tabular}




\begin{tabular}{|c|c|c|c|c|c|}
\hline Passeriformes/Parulidae & Geothlypis_aequinoctialis & 7 & 1 & 0 & 2 \\
\hline Passeriformes/Parulidae & Myiothlypis_flaveola & 6 & 13 & 0 & 1 \\
\hline Passeriformes/Parulidae & Setophaga_pitiayumi & 1 & 8 & 0 & 0 \\
\hline Passeriformes/Passerellidae & Ammodramus_humeralis & 3 & 0 & 0 & 5 \\
\hline Passeriformes/Passerellidae & Arremon_flavirostris & 0 & 2 & 0 & 0 \\
\hline Passeriformes/Passerellidae & Zonotrichia_capensis & 10 & 8 & 14 & 15 \\
\hline Passeriformes/Rhynchocyclidae & Hemitriccus_margaritaceiventer & 4 & 2 & 0 & 0 \\
\hline Passeriformes/Rhynchocyclidae & Todirostrum_cinereum & 0 & 1 & 0 & 2 \\
\hline Passeriformes/Rhynchocyclidae & Tolmomyias_sulphurescens & 0 & 0 & 0 & 1 \\
\hline Passeriformes/Thamnophilidae & Formicivora_rufa & 1 & 0 & 0 & 0 \\
\hline Passeriformes/Thamnophilidae & Herpsilochmus_atricapilus & 3 & 0 & 0 & 1 \\
\hline Passeriformes/Thamnophilidae & Herpsilochymus_longirostris & 0 & 1 & 0 & 0 \\
\hline Passeriformes/Thamnophilidae & Taraba_major & 0 & 1 & 0 & 0 \\
\hline Passeriformes/Thamnophilidae & Thamnophilus_pelzelni & 1 & 2 & 0 & 0 \\
\hline Passeriformes/Thraupidae & Coereba_flaveola & 1 & 4 & 0 & 0 \\
\hline Passeriformes/Thraupidae & Coryphospingus_cucullatus & 0 & 2 & 0 & 0 \\
\hline Passeriformes/Thraupidae & Cypsnagra_hirundinacea & 8 & 1 & 0 & 0 \\
\hline Passeriformes/Thraupidae & Dacnis_cayana & 1 & 0 & 0 & 0 \\
\hline Passeriformes/Thraupidae & Emberizoides_herbicula & 5 & 0 & 0 & 0 \\
\hline Passeriformes/Thraupidae & Neothraupis_fasciata & 1 & 0 & 0 & 0 \\
\hline Passeriformes/Thraupidae & Ramphocelus_carbo & 1 & 2 & 0 & 0 \\
\hline Passeriformes/Thraupidae & Saltatricula_atricollis & 7 & 0 & 0 & 0 \\
\hline Passeriformes/Thraupidae & Schistochlamys_ruficapillus & 1 & 0 & 0 & 0 \\
\hline Passeriformes/Thraupidae & Sicalis_flaveola & 0 & 0 & 0 & 10 \\
\hline Passeriformes/Thraupidae & Sporophila_caerulescens & 4 & 0 & 0 & 2 \\
\hline Passeriformes/Thraupidae & Sporophila_lineola & 0 & 0 & 0 & 2 \\
\hline Passeriformes/Thraupidae & Tangara_cayana & 7 & 12 & 2 & 0 \\
\hline Passeriformes/Thraupidae & Tangara_palmarum & 0 & 0 & 0 & 1 \\
\hline Passeriformes/Thraupidae & Tangara_sayaca & 8 & 19 & 9 & 12 \\
\hline Passeriformes/Thraupidae & Tersina_viridis & 0 & 0 & 0 & 3 \\
\hline Passeriformes/Thraupidae & Volatinia_jacarina & 0 & 0 & 0 & 3 \\
\hline Passeriformes/Troglodytidae & Cantorchilus_leucotis & 1 & 0 & 0 & 3 \\
\hline Passeriformes/Troglodytidae & Troglodytes_musculus & 3 & 7 & 4 & 13 \\
\hline Passeriformes/Troglodytidae & Turdus_leucomelas & 9 & 21 & 14 & 5 \\
\hline Passeriformes/Turdidae & Turdus_amaurochalinus & 3 & 4 & 0 & 2 \\
\hline Passeriformes/Turdidae & Turdus_rufiventris & 0 & 1 & 0 & 0 \\
\hline Passeriformes/Tyrannidae & Camptostoma_obsoletum & 5 & 11 & 0 & 2 \\
\hline Passeriformes/Tyrannidae & Cnemotriccus_fuscatus & 0 & 3 & 0 & 0 \\
\hline Passeriformes/Tyrannidae & Colonia_colonus & 0 & 0 & 0 & 2 \\
\hline Passeriformes/Tyrannidae & Elaenia_chiriquensis & 22 & 10 & 0 & 1 \\
\hline Passeriformes/Tyrannidae & Elaenia_flavogaster & 17 & 12 & 1 & 10 \\
\hline Passeriformes/Tyrannidae & Elaenia_mesoleuca & 1 & 0 & 0 & 0 \\
\hline Passeriformes/Tyrannidae & Elaenia_obscura & 1 & 3 & 0 & 0 \\
\hline Passeriformes/Tyrannidae & Empidonomus_varius & 0 & 1 & 0 & 0 \\
\hline Passeriformes/Tyrannidae & Fluvicola_nengeta & 0 & 0 & 0 & 2 \\
\hline Passeriformes/Tyrannidae & Gubernetes_yetapa & 1 & 0 & 0 & 0 \\
\hline
\end{tabular}




\begin{tabular}{|c|c|c|c|c|c|}
\hline Passeriformes/Tyrannidae & Lathrotriccus_euleri & 0 & 1 & 0 & 0 \\
\hline Passeriformes/Tyrannidae & Machetornis_rixosa & 0 & 0 & 0 & 2 \\
\hline Passeriformes/Tyrannidae & Megarynchus_pitangua & 2 & 5 & 3 & 1 \\
\hline Passeriformes/Tyrannidae & Myiarchus_ferox & 0 & 2 & 0 & 0 \\
\hline Passeriformes/Tyrannidae & Myiarchus_swainsoni & 1 & 3 & 0 & 0 \\
\hline Passeriformes/Tyrannidae & Myiarchus_tyrannulus & 7 & 7 & 1 & 4 \\
\hline Passeriformes/Tyrannidae & Myiodynastes_maculatus & 2 & 0 & 7 & 1 \\
\hline Passeriformes/Tyrannidae & Myiophobus_fasciatus & 1 & 0 & 0 & 0 \\
\hline Passeriformes/Tyrannidae & Myiozetetes_similis & 0 & 0 & 0 & 2 \\
\hline Passeriformes/Tyrannidae & Phaeomyias_murina & 9 & 4 & 0 & 0 \\
\hline Passeriformes/Tyrannidae & Pitangus_sulphuratus & 1 & 8 & 2 & 18 \\
\hline Passeriformes/Tyrannidae & Serpophaga_subcristata & 1 & 1 & 0 & 0 \\
\hline Passeriformes/Tyrannidae & Tyrannus_melancholicus & 5 & 9 & 3 & 9 \\
\hline Passeriformes/Tyrannidae & Tyrannus_savana & 5 & 3 & 2 & 12 \\
\hline Passeriformes/Vireonidae & Cycharhis_gujanensis & 1 & 7 & 1 & 0 \\
\hline Passeriformes/Vireonidae & Vireo_chivi & 0 & 5 & 1 & 1 \\
\hline Passeriformes/Vireonidae & Vireo_olivaceus & 0 & 1 & 1 & 0 \\
\hline Pelecaniformes/Ardeidae & Syrigma_sibilatrix & 0 & 0 & 0 & 2 \\
\hline Pelecaniformes/Threskiornithidae & Theristicus_caudatus & 0 & 0 & 0 & 3 \\
\hline Piciformes/Picidae & Colaptes_campestris & 5 & 0 & 0 & 7 \\
\hline Piciformes/Picidae & Colaptes_melanochloros & 0 & 1 & 0 & 0 \\
\hline Piciformes/Picidae & Dryocopus_lineatus & 0 & 0 & 1 & 1 \\
\hline Piciformes/Picidae & Melanerpes_candidus & 1 & 0 & 1 & 3 \\
\hline Piciformes/Picidae & Picumnus_albosquamatus & 0 & 1 & 0 & 0 \\
\hline Piciformes/Ramphastidae & Ramphastos_toco & 2 & 0 & 1 & 2 \\
\hline Psittaciformes/Psittacidae & Amazona_aestiva & 0 & 0 & 0 & 2 \\
\hline Psittaciformes/Psittacidae & Brotogeris_chiriri & 2 & 2 & 0 & 9 \\
\hline Psittaciformes/Psittacidae & Forpus_xanthopterygius & 0 & 0 & 0 & 1 \\
\hline Psittaciformes/Psittacidae & Psittacara_leucophthalmus & 1 & 2 & 1 & 7 \\
\hline Strigiformes/Strigidae & Athene_cunicularia & 0 & 0 & 0 & 3 \\
\hline Tinamiformes/Tinamidae & Crypturellus_parvirostris & 13 & 3 & 0 & 0 \\
\hline Tinamiformes/Tinamidae & Nothura_maculosa & 0 & 0 & 0 & 1 \\
\hline
\end{tabular}


Tabela S3: Valores obtidos no Teste de Tukey realizado após o teste ANOVA com nível de significância $=0,05$.

\begin{tabular}{ll}
\hline Riqueza biológica & \\
\hline Teste de Tukey & P-valor \\
cerrado fechado-cerrado aberto & 0.9915933 \\
eucalipto-cerrado aberto & $0.0000007^{*}$ \\
pasto-cerrado aberto & 0.9999049 \\
eucalipto-cerrado fechado & $0.0000002^{*}$ \\
pasto-cerrado fechado & 0.9959944 \\
pasto-eucalipto & $0.0000005^{*}$ \\
\hline & \\
\hline Riqueza Funcional Massa & P-valor \\
\hline cerrado fechado-cerrado aberto & 0.7676181 \\
eucalipto-cerrado aberto & 0.2027996 \\
pasto-cerrado aberto & 0.7682009 \\
eucalipto-cerrado fechado & 0.7436201 \\
pasto-cerrado fechado & 0.2197714 \\
pasto-eucalipto & $0.0205327^{*}$ \\
\hline \hline & \\
\hline \hline Riqueza Funcional - Local de nidificação \\
\hline $\begin{array}{l}\text { cerrado fechado-cerrado aberto } \\
\text { eucalipto-cerrado aberto }\end{array}$ & 0.8157330 \\
$\begin{array}{l}\text { pasto-cerrado aberto } \\
\text { eucalipto-cerrado fechado }\end{array}$ & $0.0025930^{*}$ \\
pasto-cerrado fechado & $0.0131183^{*}$ \\
pasto-eucalipto & $0.0360682^{*}$ \\
\hline
\end{tabular}

\begin{tabular}{ll}
\hline Riqueza Funcional Multivariada & \\
\hline Teste de Tukey & P-valor \\
cerrado fechado-cerrado aberto & 0.9987797 \\
eucalipto-cerrado aberto & $0.0143572^{*}$ \\
pasto-cerrado aberto & $0.0000010^{*}$ \\
eucalipto-cerrado fechado & $0.0091769^{*}$ \\
pasto-cerrado fechado & $0.0000019^{*}$ \\
pasto-eucalipto & $0.0000000^{*}$ \\
\hline
\end{tabular}

\begin{tabular}{ll}
\hline Riqueza Funcional - Dieta & \\
\hline cerrado fechado-cerrado aberto & 0.5669315 \\
eucalipto-cerrado aberto & 0.1815289 \\
pasto-cerrado aberto & $0.0021046^{*}$ \\
eucalipto-cerrado fechado & $0.0064981^{*}$ \\
pasto-cerrado fechado & 0.0868183 \\
pasto-eucalipto & $0.0000007^{*}$ \\
\hline
\end{tabular}

\begin{tabular}{ll}
\hline \multicolumn{2}{l}{ Riqueza Funcional - Estratégia de forrageio } \\
\hline cerrado fechado-cerrado aberto & 0.9698745 \\
eucalipto-cerrado aberto & 0.1088416 \\
pasto-cerrado aberto & $0.0000000^{*}$ \\
eucalipto-cerrado fechado & 0.2630374 \\
pasto-cerrado fechado & $0.0000000^{*}$ \\
pasto-eucalipto & $0.0000000^{*}$ \\
\hline
\end{tabular}

